ins zesí

\title{
WATER RESOURCES OF THE \\ KENAI-SOLDOTNA AREA, ALASKA
}

by Gary S. Anderson and Stanley H. Jones

\section{UNITED STATES DEPARTMENT OF THE INTERIOR GEOLOGICAL SURVEY \\ Water Resources Division, Alaska District}

$$
\text { Open-File Report }
$$

Prepared in cooperation with the Kenai Peninsula Borough

$$
\begin{gathered}
1972 \\
72-7
\end{gathered}
$$

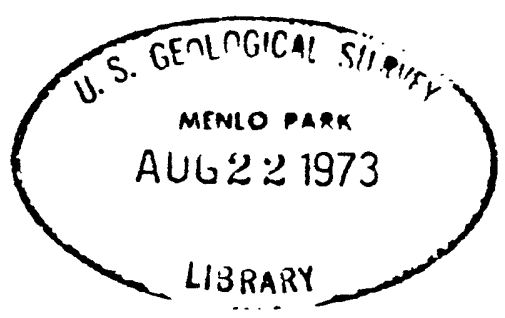




\section{CONTENTS}

Page

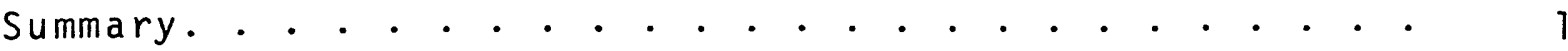

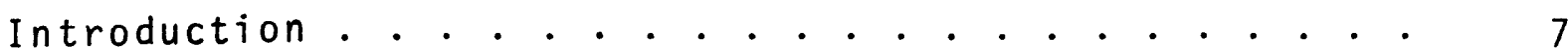

Purpose and scope. . . . . . . . . . . . . . . 7

Location and extent of the area . . . . . . . . . 7

History of water-resources development and

investigations. . . . . . . . . . . . . . 9

Climate. . . . . . . . . . . . . . . . . . . . . . . . .

Geologic units and their hydrologic characteristics. . 15

Kenai Group . • . . . . . . . . . . . . 15

Unconsolidated Quaternary deposits. . . . . . . . . 17

Hydrology . • . . . . . . . . . . . . . . . . . . . 18

Streamflow. . . . . . . . . . . . . . . 20

Variability of streamflow. . . . . . . . . 21

Low flow............... . . . . . . 23

Floods.................. . . . 26

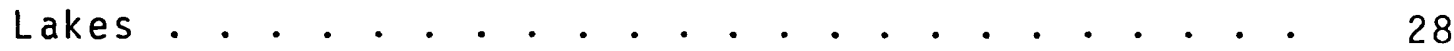

Ground water. . . . . . . . . . . . . . . 30

The ground-water reservoir . . . . . . . 30

Recharge . . . . . . . . . . . . . 31

Movement . . . . . . . . . . . . . . 31

Discharge. . . . . . . . . . . . . . 33

Fluctuations of water levels... . . . . 38

Ground-water storage. . . . . . . . . . 40

Ground-water development . . . . . . . . 41

Domestic supplies... . . . . . . . . . 41

Industrial and municipal supplies... . 42

North Kenai. . . . . . . . . . 43

Kenai. . . . . . . . . . . 50

Beaver Creek valley. . . . . . . . 51

Soldotna.......... . . . . 54 


\section{CONTENTS -- Continued}

Page

Quality of water................. . 56

Chemical constituents in relation to use. . . . . 56

Ground-water quality. . . . . . . . . . 59

Water-table aquifers.......... . 59

Artesian aquifers............ . 59

Generally satisfactory ground water. . . 63

Generally unsatisfactory ground water. . 63

Saline ground water. . . . . . . . . . 64

Surface-water quality........... . . 64

Chemical quality of surface water. . . . . 65

Sediment.............. . 66

Temperature.............. . 69

Salt-water encroachment - Kenai River. . . . 69

Future development of water resources. . . . . . . . 73

References cited... . . . . . . . . . . . 79 


\section{CONTENTS}

Page

Summary • • • • • • • • • • •

Introduction . . . . . . . . . . . . . . . . . . . 7

Purpose and scope . . . . . . . . . . . . . . . 7

Location and extent of the area. . . . . . . . . 7

History of water-resources development and

investigations. . . . . . . . . . . . . . . 9

Climate. . . . . . . . . . . . . . . . . . . . . . . . . 11

Geologic units and their hydrologic characteristics. . 15

Kenai Group . . . . . . . . . . . . . . . 15

Unconsolidated Quaternary deposits. . . . . . . . 17

Hydrology. . . . . . . . . . . . . . . . . . 18

Streamflow. . . . . . . . . . . . . . . 20

Variability of streamflow. . . . . . . . 21

Low flow... . . . . . . . . . . . . 23

Floods................... . . . 26

Lakes . . . . . . . . . . . . . . . . 28

Ground water. . . . . . . . . . . . . . 30

The ground-water reservoir. . . . . . . 30

Recharge. . . . . . . . . . . . . . 31

Movement . . . . . . . . . . . . . 31

Discharge. . . . . . . . . . . . . . 33

Fluctuations of water levels....... . . 38

Ground-water storage . . . . . . . . . . 40

Ground-water development . . . . . . . . 41

Domestic supplies... . . . . . . . . 41

Industrial and municipal supplies . . . 42

North Kenai. . . . . . . . . . 43

Kenai. . . . . . . . . . . . 50

Beaver Creek valley. . . . . . . 51

Soldotna. . . . . . . . . . . 54 


\section{ILLUSTRATIONS}

[Prates are in pocket]

Plates 1-2. Maps showing:

1. Surficial geology and geohydrology.

2. Surface-water basins; hydrographs of

seasonal and year-to-year maximum, minimum, and mean discharge, Kenai

and Kasilof Rivers and Beaver Creek;

and table showing summary of surfacewater gaging-station and partial records.

Figure 1. Location of the Kenai-Soldotna area.....

2-5. Graphs showing:

2. Ground-water use, by year, in the KenaiSoldotna area............ . 10

3. Annual precipitation at Kenai Airport, 1950-70..............

4. Variation of monthly temperature and precipitation at Kenai Airport and pan evaporation at the Matanuska Agricul-

tural Experiment Station near Palmer.

5. Net deficiency of precipitation at Kenai

Airport, 1968-70...........

6. Diagram of the hydrologic cycle related to the Kenai area.

7. Duration curves of daily flow, Kenai and

Kasilof Rivers and Beaver Creek . . . .

8. Low-flow frequency curves (30-day periods), Kenai and Kasilof Rivers. . . . . . . . 


\section{ILLUSTRATIONS--Continued}

Page

Figure 9. Frequency of floods at Kasilof River near Kasilof and the Kenai River at Cooper Landing and at Soldotna... . . . . .

10. Photograph of Lake Suneva near Kenai showing decline of water level, summer 1970... .

11. Ground-water recharge and discharge areas and ground-water pumpage. . . . . . . .

12. Comparable discharges at selected sites on rivers in the Kenai-Soldotna area.....

13-15. Hydrographs showing:

13. Beaver Creek discharge showing separa-

tion of the monthly surface runoff and ground-water runoff components. . .

14. Relationship of water-table hydrographs and precipitation... . . . . . .

15. Relationship of artesian hydrographs, precipitation, and withdrawal of ground water. . . . . . . . . .

16. Frequency distribution of domestic well depths

in the Kenai-Soldotna area. . . . . . . .

17. Aquifer test of Collier Carbon and Chemical production well (well 10602), October 8 , 1971.

18. Ground-water basins . . . . . . . . . 46

19. North Kenai industrial ground-water pumpage. 48

20. Predicted time-drawdown for Collier Carbon

and Chemical observation well 5B

(we11 10004).............

21. Aquifer test of Kenai production well

(wel1 10871), August 11, 1970......

22. Aquifer test of Soldotna production well

(we11 10161), July 23, 1971....... 


\section{ILLUSTRATIONS--Continued}

Page

Figure 23. Concentration of chemical constituents in surface and ground water in Kenai-

Soldotna area. . . . . . . . . . .

24. Iron content in water-table aquifer of the

Kenai-Soldotna area. . . . . . . . . .

25. Comparison of dissolved-solids content with

discharge of the Kenai and Kasilof Rivers

and Beaver Creek. . . . . . . . . .

26. Comparison of suspended-sediment discharge

with water discharge of the Kenai and Kasilof Rivers.............

27. Comparison of temperature with daily dis-

charge for station 15-2665.00: Beaver Creek near Kenai, 1969-70. . . . . . .

28. Cumulative frequency curve of water temperature, Beaver Creek near Kenai, 1969-70. . 70

29. Seasonal variability of water temperature, Kenai River at Soldotna. . . . . . . 71

30. Salt-water encroachment, Kenai River, May 2, 1969............... 72 


\section{TABLES}

Page

Table 1. Generalized stratigraphic section of the waterbearing sediments in the Kenai-Soldotna area. 16

2. Occurrence and magnitude of Snow River outburst floods for Kenai River at Cooper Landing. . . 29 3-4. Selected chemical analyses, Kenai-Soldotna area:

3. Ground water. . . . . . . . . . 57

4. Surface water. . . . . . . . . . . 57

5. Source, significance, and concentrations of dissolved mineral constituents and physical properties of Kenai-Soldotna area water. . .

6. Relationship of 112 chemical analyses by geohydrologic groupings to U.S. Public Health Service water-quality limits. . . .

7. Relationship of chemical analyses from five streams to U.S. Public Health Service waterquality limits............. . . 66

8. Summary of suspended-sediment data. . . . . . 68 


\section{WATER RESOURCES OF THE KENAI-SOLDOTNA AREA, ALASKA}

Sy Gary S. Anderson and Stanley $H$. Jones

\section{SUMMARY}

- vater is abundantly available throughout the Kenai-Soldotna area, but its poor quality in some areas and the high cost of development either present restrictions or interpose economic considerations on its use.

- Total water use during 1970 was approximately 1,260 million gallons, almost entirely supplied from wells. The major water users were industrial plants, which pumped 890 million gallons during 1970 .

- Precipitation is the principal source of all potable water. Precipitation averages 19.91 inches per year at the Kenai Airport. However, total precipitation was greatly deficient for the years 1968 to 1970. By November 1969 the net deficiency was 18.16 inches, a loss of almost one normal year's precipitation in less than 2 calendar years.

- The study area is underlain by the Kenai Group of Tertiary age and unconsolidated glacial deposits of Quaternary age. The principal source of ground water is from glacial outwash and unconsolidated alluvial sediments of Quaternary age.

- The Kenai-Soldotna area is drained by glacial and nonglacial streams that differ markedly in their total volume and in their seasonal variability of flow. The Kenai River (glacial) at Cooper Landing has an average annual runoff of 58.4 inches end Beaver Creek (nonglacial) near Kenai, 6.59 inches.

- The major sources of runoff are snowmelt in the spring, छlacial melt during the summer, and rain during the fall. 
- Most streams have well-sustained low-flow periods because of ground-water and lake storage. Streams having sustained low flow have good potential for surface-water development.

- Lowest measured streamflows range from 0.12 to 0.38 cfs per sq mi. (cubic feet per second per square mile). The probability is one chance in five (20 percent) that the average discharge for 30 days during a particular year will be less than 1,000 cfs (cubic feet per second) on the Kenai River at Soldotna.

- Highest measured streamflows range from 1.37 cfs per sq mi. on nonglacial streams to 33.9 cfs per sq mi. on glacial streams.

- The numerous lakes in the study area form an important part of the total water resource. They are glacial in origin and are distributed throughout the areas mapped as glacial moraine and drift. In morainal material the lakes are perched above the regional ground-water table, but in drift they occupy depressions that extend below the ground-water level. During the period 1967 to 1970, water levels in lake basins overlying drift deposits declined as much as 6 feet largely because of the drought conditions of 1968 and 1969.

- A water-table and an artesian aquifer generally occur throughout the study area. The artesian aquifer is the principal source of ground water.

- Principal recharge to the ground-water reservoir is from local precipitation.

- Ground-water runoff during 1969 and 1970 from the Beaver Creek basin is estimated to be 4 inches per year.

- Ground-water flow rates are low. 
- Ground water is discharged by surface springs, streams, evaporation, transpiration, submarine springs, wells, artificial drains, and vertical leakage.

- Water-level fluctuations are an index to seasonal and longterm changes in ground-water storage. Ground-water levels have been generally declining since 1968, in both watertable and artesian aquifers, mainly because of drought conditions but also in the artesian aquifers because of pumpage.

- Decreases in ground-water storage from 1967 to 1970 are related to the precipitation deficiency during this period.

- Domestic ground-water supplies can be developed throughout the study area; most of the domestic wells are 100 feet or less in depth, but many have water of poor quality.

- High-capacity industrial and municipal ground-water supplies are commonly difficult to obtain. The most favorable areas for high-yield wells have been in glacial outwash deposits of North Kenai and the buried outwash of the Beaver Creek and Kenai River valleys.

- Yields from wells in the artesian aquifers of North Kenai range from 200 to $1,400 \mathrm{gpm}$ (gallons per minute). Industrial pumpage is causing a decline of artesian water levels; however, the declines are not sufficient to cause serious problems, and preliminary estimates of basin yield indicate that recharge is greater than pumpage.

- Drought conditions from 1968-1970 are believed to be the principal cause of water-level declines in the water-table aquifer and the lakes. However, ground-water pumpage from the North Kenai artesian aquifer may be contributing to the decline. 
- The water-table aquifer near Kenai contains large amounts of ground water; however, the artesian aquifer is poorly defined and only a few low-yielding wells penetrate it. Both aquifers have had restricted development because of objectionable quantities of iron, dissolved minerals, or organic material.

- Well yields of the Beaver Creek artesian aquifer are as much as $1,000 \mathrm{gpm}$. The Beaver Creek valley should have good potential for development. Conflicts in water use can be avoided by proper management.

- Well yields of the Soldotna artesian aquifer range from 10 to $500 \mathrm{gpm}$. Ground-water pumpage is causing local decline of the potentiometric surface; however, such a decline is normal and no adverse effects are anticipated provided future high-capacity wells are spaced to minimize mutual interference.

- Dissolved mineral constituents and physical properties of water that are objectionable in the study area include: iron, chloride, dissolved solids, color, odor, and turbidity.

- The highest and most objectionable iron content occurs in water-table aquifers near Kenai.

- The artesian aquifer can be separated into an area of generally satisfactory quality and an area of generally unsatisfactory quality.

- Artesian water of satisfactory quality comes from 60 to 300 feet below land surface and occurs inland from the coast. It is generally the best water in the area.

- Artesian water of unsatisfactory quality ranges in depth from 100 to 450 feet.below land surface and occurs near the natural discharge areas. Many samples from this zone have dissolved-solids contents of more than $250 \mathrm{mg} / 1$ (milligrams per liter) or color of more than 75 units. 
- Surface water is generally of good quality; however, nonglacial streams have excessive iron and color and glacial streams are heavily laden with glacial flour.

- The sediment concentrations and total sediment discharge of glacial streams in the Kenai-Soldotna area are relatively small in relation to the amount of stream discharge. However, these streams do contain fine suspended-sediment concentrations throughout the year; the resulting turbidity makes the water undesirable for some uses.

- Measured surface-water temperature in the Kenaj-Soldotna area ranges from near freezing to $17^{\circ} \mathrm{C}\left(62^{\circ} \mathrm{F}\right)$.

- Observations during a period of low flow and maximum tides in the Kenai River indicate that a salt-water wedge encroached to Eagle Rock, 12 miles above the river mouth.

- Domestic water requirements should double by 1977; however, this projected demand can probably be satisfied by individual domestic ground-water wells.

- Projected industrial requirements may increase the demand by $4.5 \mathrm{mgd}$ (milion gallons per day) in the foreseeable future.

- Expanded industrial development in North Kenai may require new sources of water or proper management of the present source.

- Additional ground water is probably available from waterbearing deposits underlying the cities of Soldotna and Kenai and from the Beaver Creek valley and the Kenai River valley downstream from soldotna.

- The development of additional ground-water sources will require proper management of the reservoir including continual inventory of components in the hydrologic cycle and definition of the undesirable results of pumping that must be avoided. 
- Maximum use of ground-water reservoirs cannot be achieved by holding the storage constant; it is achieved by drawing on storage during dry years, but only to the extent that the storage can be replenished during wet years.

- The largest untapped source of water is the Kenai River. However, it is heavily laden with glacial flour and treatment would be required. It would be desirable to develop a.unified water system using ground water in conjunction with surface water for temperature control and to supplement the surface water during times of heavy load on treatment facilities, such as during periods of peak sediment concentration.

- A unified system can be envisioned to include: (1) Several milition gallons per day supply of surface water from an infiltration gallery or run-of-the-river intake of water from the Kenai River somewhere above Eagle Rock, (2) 3 mgd from water wells near Soldotna, (3) 3 mgd from ground-water wells in Beaver Creek valley, and (4) 2 to 6 mgd from ground-water wells near North Kenai. 


\section{INTRODUCTION}

\section{Purpose and Scope}

This report summarizes the results of a water-resources investigation in the Kenai-Soldotna area by the U.S. Geological Survey in cooperation with the Kenai Peninsula Borough. The investigation was started in July 1967 and expanded in 1969 and 1970 to include cooperation with the city of Kenai.

The purposes of the investigation were: (1) To provide a general areawide appraisal of the water resources, (2) to appraise the availability and quality of municipal and industrial water supplies, and (3) to evaluate the effects of industrial pumpage in North Kenai. The information obtained during the study will be useful in future waterresources development and management. Much of the area is now undeveloped but part is developing at a rapid pace. There has not been sufficient time to evaluate comprehensively the long-term effects of this progressive development on the water resources.

The work was done under the supervision of Harry Hulsing, district chief, U.S. Geological Survey, Alaska District.

\section{Location and Extent of the Area}

The Kenai-Soldotna area, as defined for this report, encompasses approximately 900 square miles on the east shore of Cook Inlet and includes the communities of North Kenai, Kenai, Soldotna, Sterling, and Kasilof (fig. 1). 


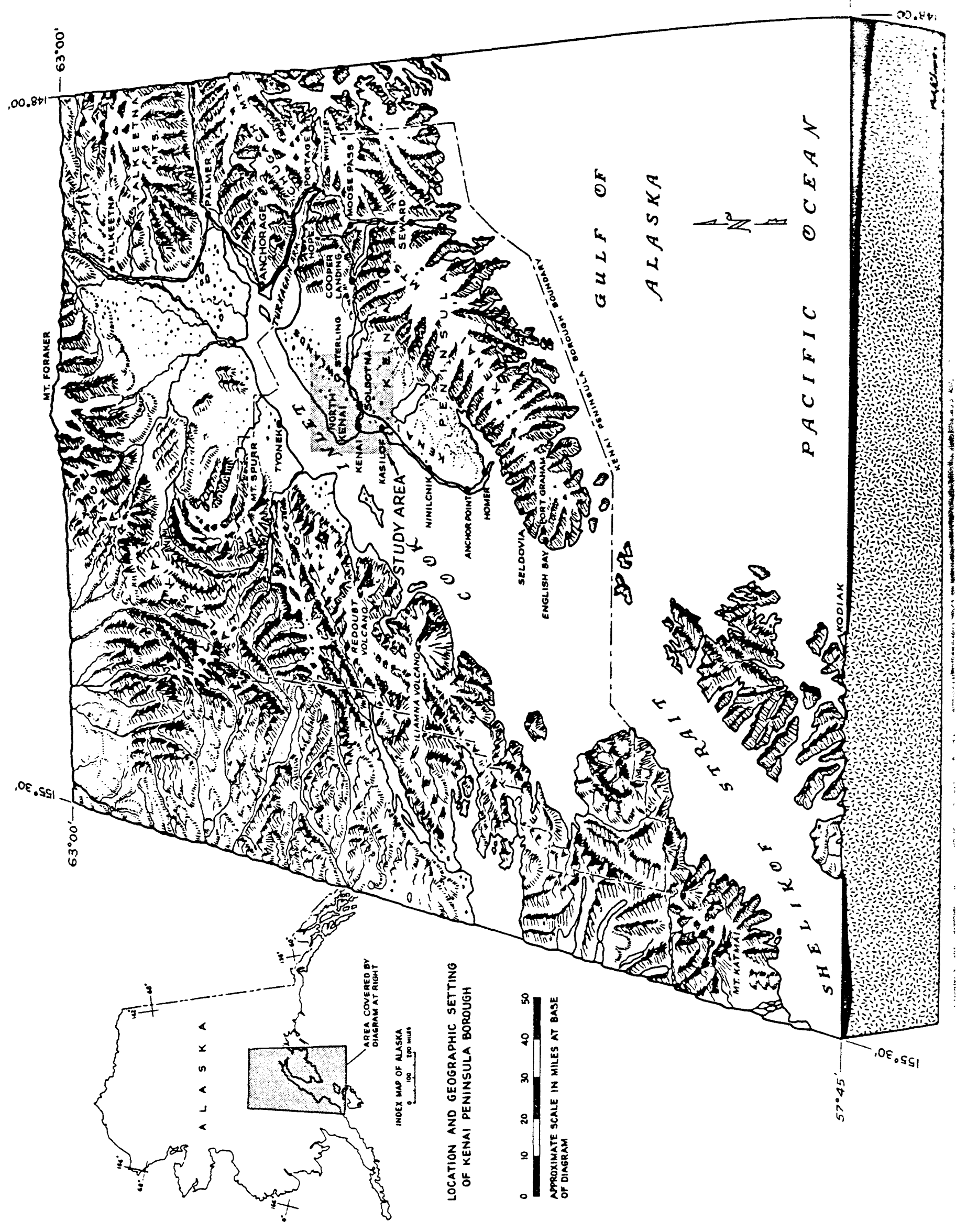




\section{History of Water-Resources Development and Investigations}

In the study area, original domestic water supplies were obtained from surface water or shallow dug wells. The first known deep water well in the area was drilled to a depth of 187 feet at the Kenai Federal Aviation Administration Station in 1943. This well produced a small quantity of water, which was reported to be too salty for use. Consequently, water continued to be obtained from shallow dug wells, lakes, and small streams. During the early 1950's, several wells, ranging in depth from 50 to 700 feet, were drilled by cabletool methods. More recently, wells producing as much as 300 gpm of good quality water have been drilled near Soldotna, along the Kenai River valley, and in North Kenai. However, the wells drilled near Kenai have all produced only small amounts of poor quality water. The U.S. Army Corps of Engineers has conducted ground-water investigations and drilled wells at Wildwood Air Force Base from the early 1950's to the present (1970), but these wells have had small yields.

The first municipal water-distribution system in the area was constructed at Kenai in 1964. By 1968 it included 10 shallow wells that produced 35 to $50 \mathrm{gpm}$ each. Also during the 1960 's, three subdivision systems that obtained water from wells were constructed. In 1970, the city of Kenai built a reservoir, to insure water for fire demands, on a small unnamed tributary to Cook Inlet. To date, this reservoir has not been used, but it is the only major attempt to utilize surface water.

Pumpage of ground water for industrial use started in North Kenai in 1962, and industrial requirements accelerated from 1966 to 1970 (fig. 2). An intensified exploration program for developing ground water was conducted by Dames and Moore for Collier Carbon and Chemical Corp. (Dames and Moore, 


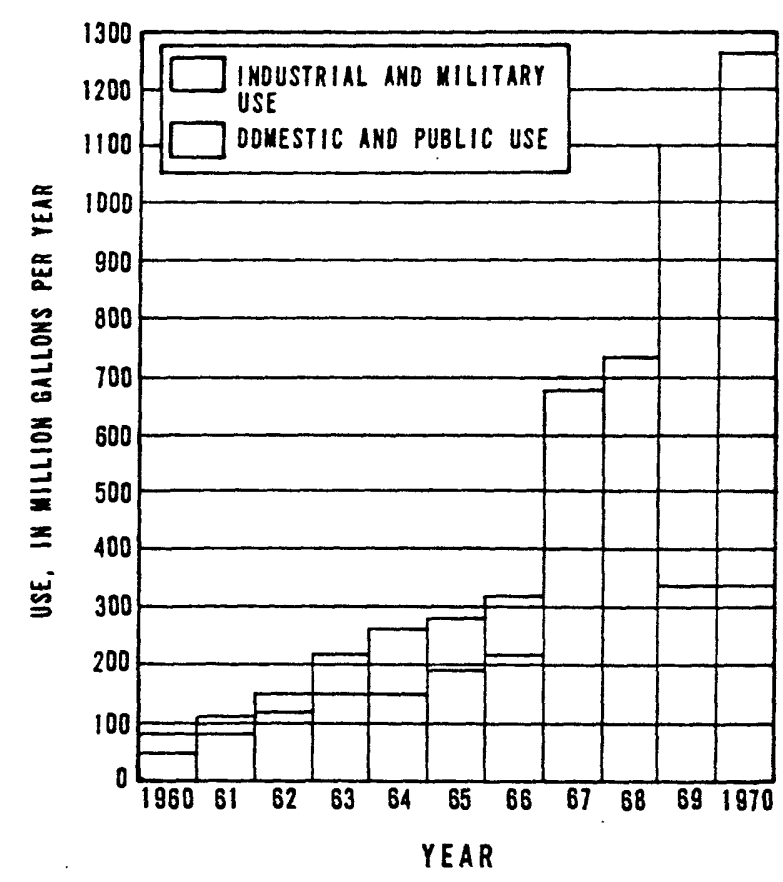

Figure 2.--Ground-water use, by year, in the Kenai-Soldotna area.

1967). As a result of their study, three wells were constructed, each capable of pumping from 1,000 to $1,400 \mathrm{gpm}$, the largest well yields in the area.

In 1967, the Kenai Peninsula Borough recognized the need for comprehensive water-resources information and arranged for the U.S. Geological Survey to initiate a cooperative study. Information obtained through 1970 is summarized in this report. Earlier reports resulting from the cooperative study include progress reports (Anderson and Jones, 1968 and 1969) and a hydrologic basic-data release (Anderson and Jones, 1971).

In 1968, Adams, Corthell, Lee, Wince, and Associates prepared a comprehensive water and sewer report for the city of Soldotna. Their report discussed results of test drilling near the city and recommended drilling a production well for municipal supply. 
In 1969, the city of Kenai and the U.S. Geological Survey cooperated in a ground-water exploration program in Beaver Creek valley east of Kenai. Tests indicate the aquifer is capable of yielding $1,000 \mathrm{gpm}$ to individual wells. The results of this study were summarized by Anderson (1971). The city of Kenai has since constructed a production well in Beaver Creek valley; this now satisfies their municipal water requirements of approximately. $400 \mathrm{gpm}$.

Tryck, Nyman and Hayes (1970) prepared a comprehensive water and sewer report that presented general conclusions and recommendations pertaining to future growth and development and the related water systems for the Kenai Borough. Also, other private consultants have made studies that have aided in the planning and development of water resources within the study area.

During 1970, the total ground-water withdrawal in the. Kenai-Soldotna area was approximately 1,260 million galions ( $3.4 \mathrm{mgd})$. Of this total, 890 million gallons were used by the six major industrial plants and associated service companies. This industrial water was obtained from i6 wells ranging in depth from 74 to 308 feet and in yieid from 300 to $1,400 \mathrm{gpm}$. The remaining 370 millior gallons were withdrawn by small industrial plants, trailer courts, public facilities, wildwood Air Force Base, private residences, and the city of Kenai. This water was produced from approximately 2,000 wells, mostly private with small yields, altrough the city of Kenai well is capable of producing $800 \mathrm{gpm}$.

\section{CLIMATE}

The Kenai-Soldotna area lies in a transitional climate zone influenced by both maritime and continental factors (Watson, 1959). Although the long-term averace precipitation at Kenai is 19.91 inches per year, both the yearly (fig. 3) and the monthly (fig. 4) precipitation vary greatly, with the 
greatest amount of precipitation in August and September and the least in April and May.

The maximum range in temperature at kenai, from $-44^{\circ} \mathrm{C}$ $\left(-48^{\circ} \mathrm{F}\right)$ to $34^{\circ} \mathrm{C}\left(93^{\circ} \mathrm{F}\right)$, is typical of a continental climate. The mean annual temperature is $0.7^{\circ} \mathrm{C}\left(33^{\circ} \mathrm{F}\right)$ and the average temperature during the warmest month of the year, June, is $12.1^{\circ} \mathrm{C}\left(53.7^{\circ} \mathrm{F}\right)$. The maritime climatic effects commonly cause some days of above-freezing temperatures during the winter months.

of special significance to this investigation is the yearly precipitation since 1962 ( $f i g .3$ ). The precipitation from 1963 through 1967 averaged 23.07 inches per year, or 3.16 inches per year above normal. The precipitation for 1968 and 1969 averaged 11.28 inches per year or 8.70 inches per year below normal, which was the greatest 2-year deficiency during the period 1950-70. Figure 5 illustrates the accumulated precipitation since January 1968 compared to the long-term ( 22 year) average cumulative precipitation; the difference between the two curves is the net deficiency. By November 1969 the net deficiency was 18.16 inches, which is almost equivalent to the loss of one year's normal precipitation in two calendar years.

Evaporation is not measured in the Kenai-soldotna area, but data from the Matanuska Agricultural Experiment Station near Palmer (fig. 1) are included in figure 4 because general weather conditions are similar and the seasonal distribution of evaporation can be assumed to be similar. The period of maximum evaporation coincides with the period of minimum precipitation, and the minimum evaporation during the growing season coincides with the maximum precipitation. These coincidences result in a smaller water loss by evaporation than would result if the period of maximum evaporation coincided with the period of highest precioitation or if precipitation were distributed more evenly trioughout the year. 


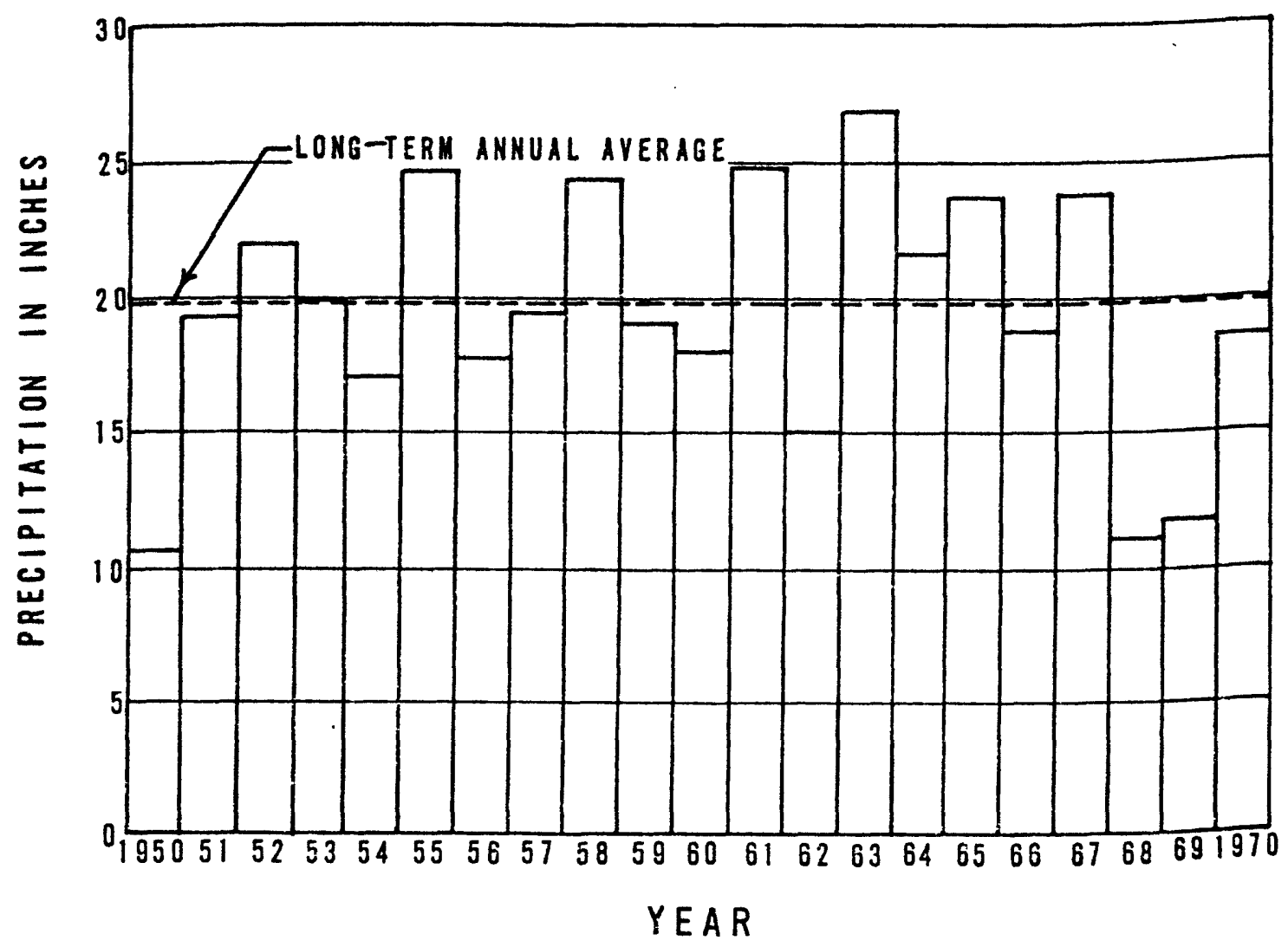

Figure 3.--Annual precipitation at Kenai Airport, 1950-70. 


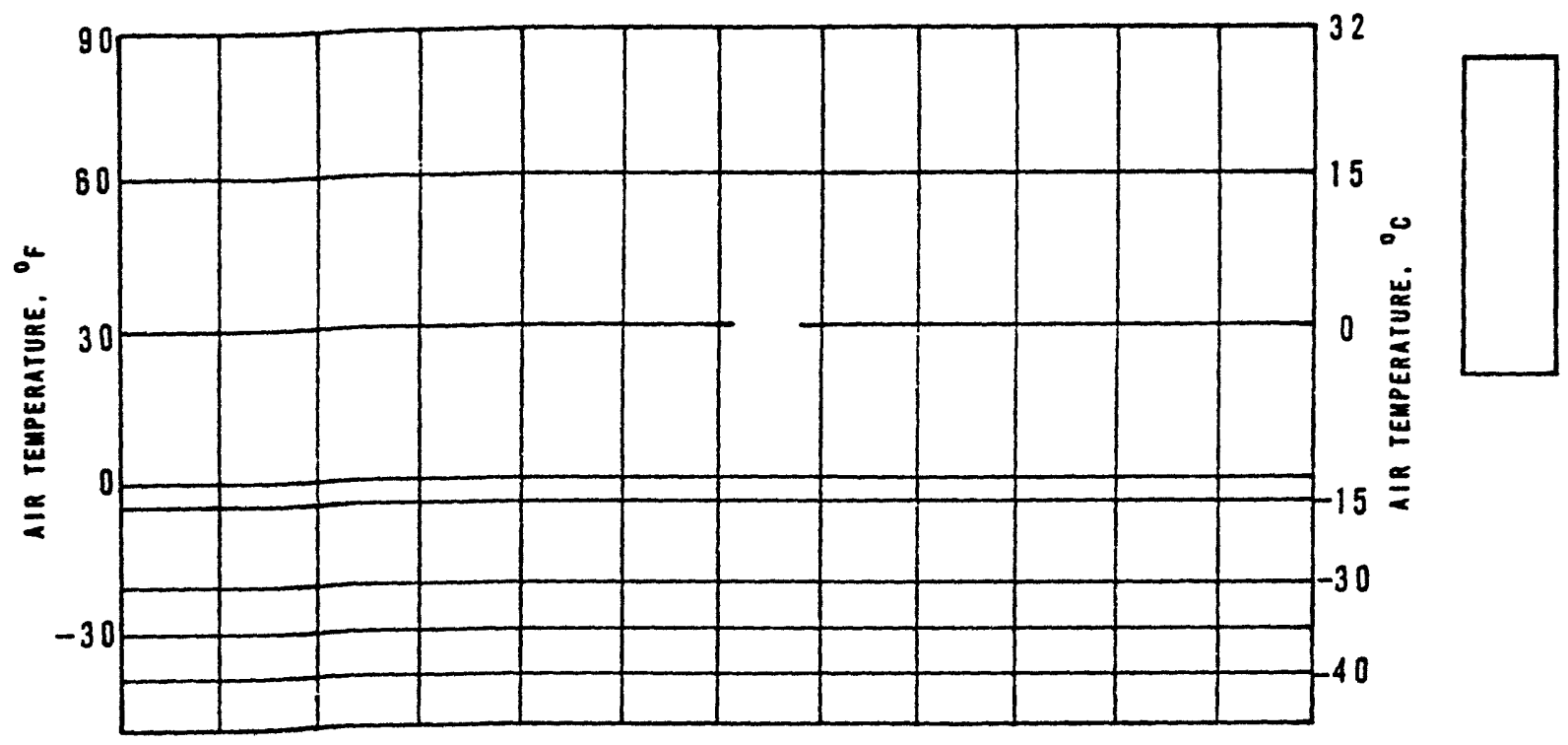

Highest doi temperatur

Meen monthi temperatur

Lonest doil temperatur

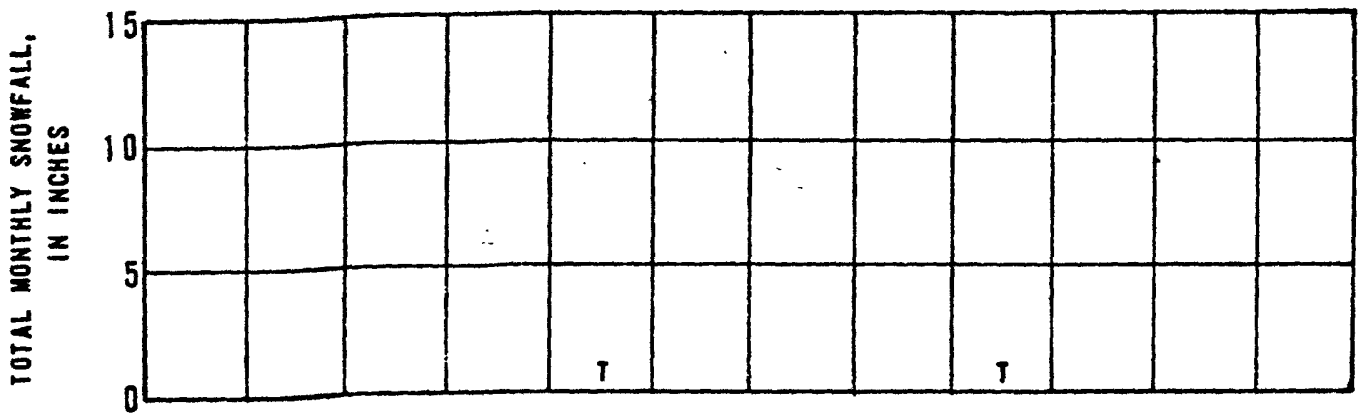

T- Trace
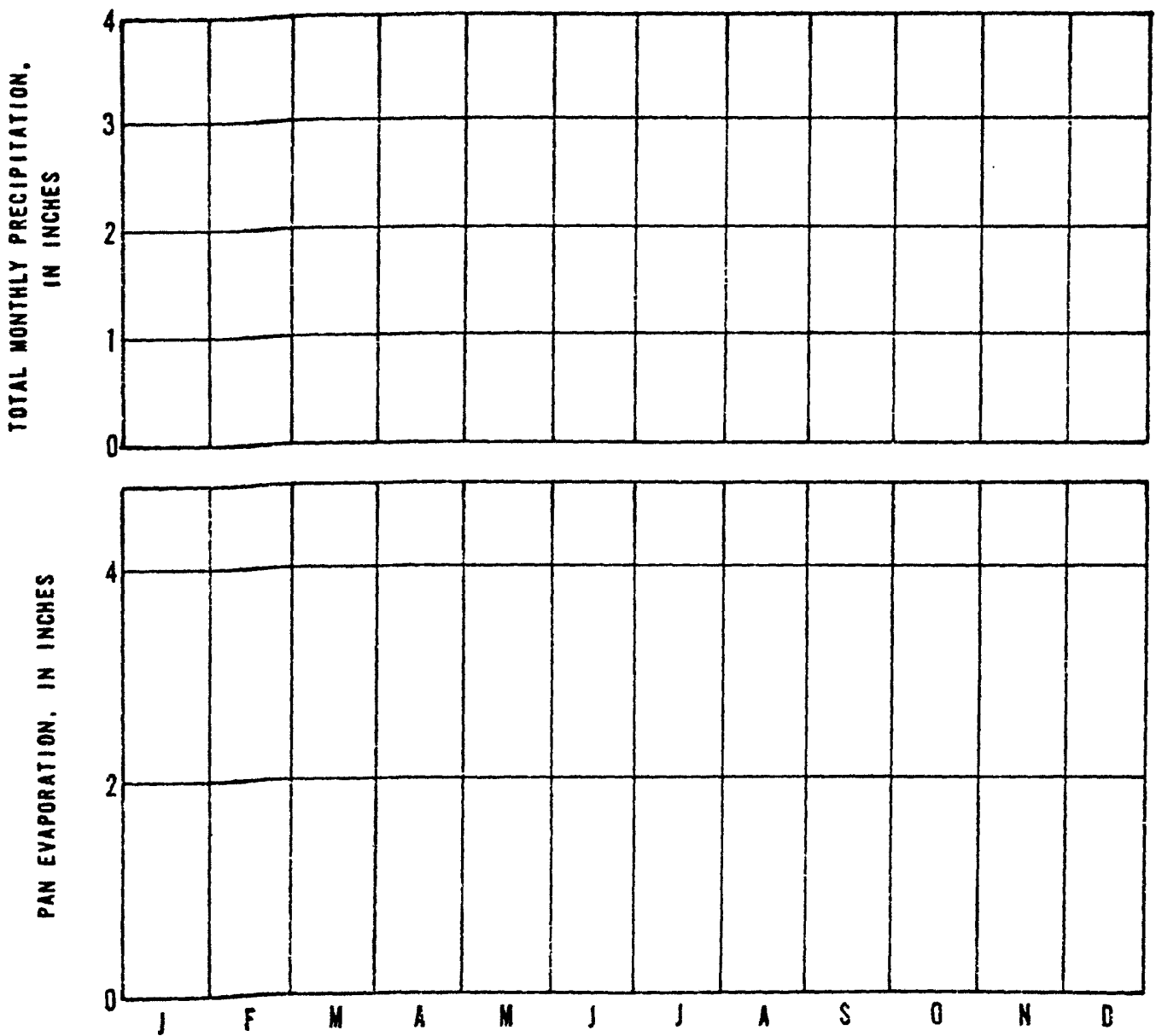

Pan ayaporation messured in the Standard Weather Buresu type pan at the Matanuska Agricultural Experiment Station near Palmer

Figure 4.--Variation of monthly temperature and precipitation at Kenai Airport and pan evaporation at the Matanuska Agricultural Experiment Station near Palmer. 


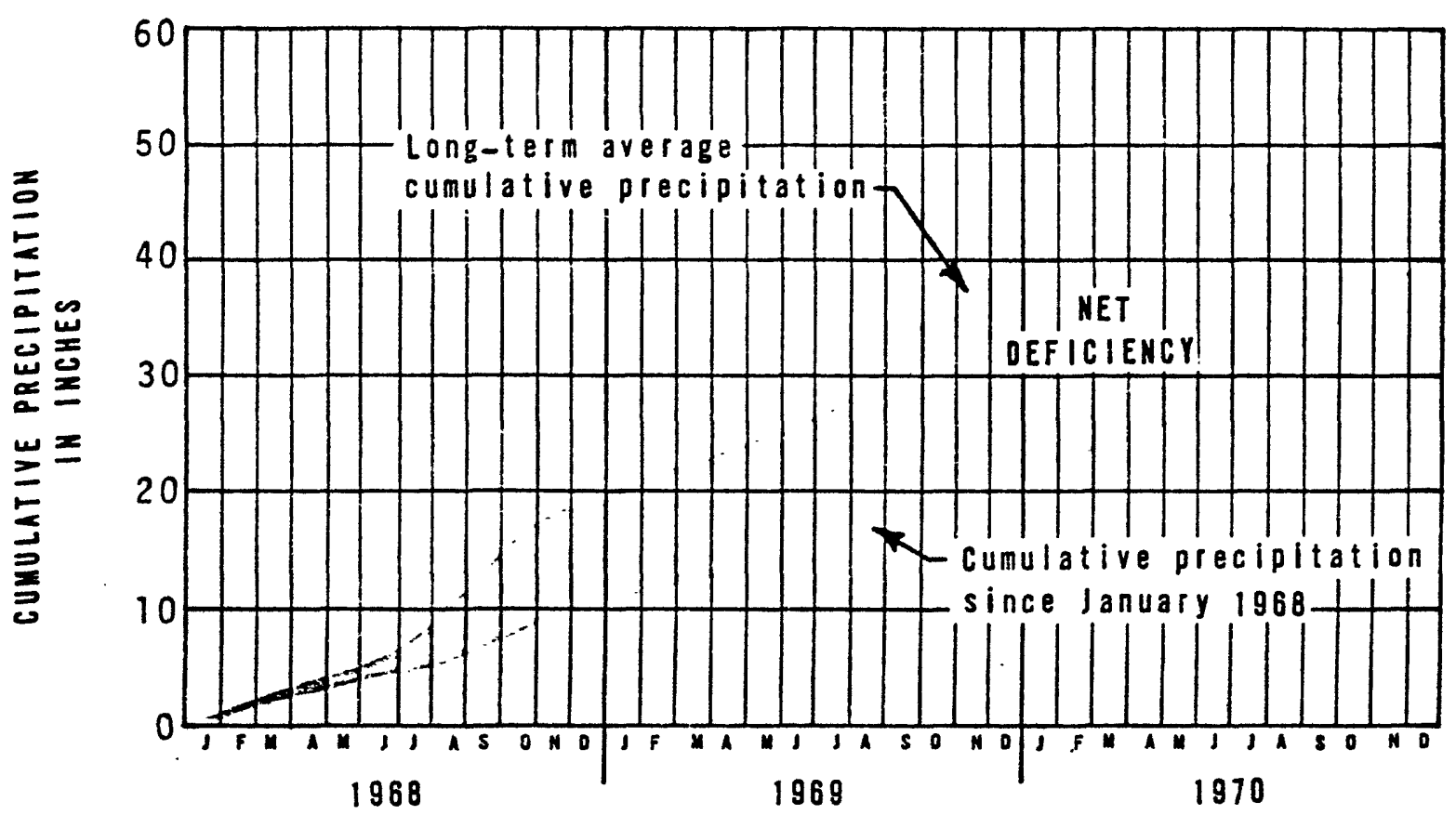

Figure 5..--Net deficiency of precipitation at Kenai Airport, 1968-70.

\section{GEOLOGIC UNITS AND THEIR HYDROLOGIC CHARACTERISTICS}

The area is underlain by the Kenai Group of Tertiary age and unconsolidated glacial deposits of Quaternary age, whose areal distribution and general physical properties are shown on plate 1. A generalized stratigraphic section of the water-bearing rocks is given in table 1 . The following discussion is partly adapted from Karlstrom (1958 and 1964).

\section{Kenai Group}

The Kenai Group crops out in sea cliffs and river tilufs near the southern border of the study area, dips to a depth 
Table 1.--Generalized stratigraphic section of the water-bearing sediments in the Kenai-Soldotna area.

\begin{tabular}{|c|c|c|}
\hline $\begin{array}{l}\text { Surficial, } \\
\text { unconfined, } \\
\text { or shallow } \\
\text { aquifer }\end{array}$ & $\Delta$ & $\begin{array}{l}\text { Sand and gravel, silt and peat. Composed } \\
\text { of all the deposits mapped on plate } 1 \text {. } \\
\text { Commonly overlain by silt or peat. Thick- } \\
\text { ness of surficial deposits } 20-100 \text { feet. }\end{array}$ \\
\hline $\begin{array}{c}\text { Confining } \\
\text { unit }\end{array}$ & 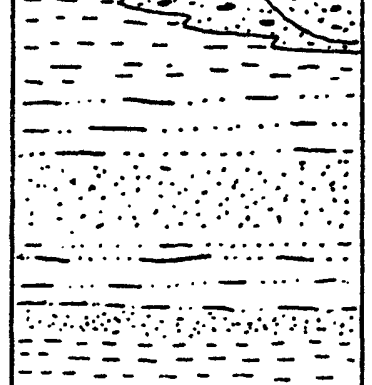 & $\begin{array}{l}\text { Clay, silt, poorly sorted clayey gravel, } \\
\text { complexely interbedded; low permeability. } \\
\text { Composed of estuarine, ice-contact, and } \\
\text { glaciomarine deposits } 20 \text { to } 100 \text { feet } \\
\text { thick. Rare permeable and water-bearing } \\
\text { lenses of sand and gravel. }\end{array}$ \\
\hline $\begin{array}{l}\text { Principal } \\
\text { artesian or } \\
\text { confined } \\
\text { aquifer }\end{array}$ & & $\begin{array}{l}\text { Sand, gravel, silt, and clay, complexely } \\
\text { interbedded. Includes principal artesian } \\
\text { aquifers. Aquifer from a few to } 100 \text { feet } \\
\text { thick, absent in some places. }\end{array}$ \\
\hline $\begin{array}{l}\text { Confining } \\
\text { unit with } \\
\text { discontin- } \\
\text { uous water- } \\
\text { bearing } \\
\text { zones }\end{array}$ & \begin{tabular}{ll}
$-\cdots$ \\
$-\cdots$ \\
$-\cdots$ \\
\hdashline$\cdots$ \\
\hdashline$\cdots$
\end{tabular} & $\begin{array}{l}\text { Clay, silt, fine silty sand; complexely } \\
\text { interbedded; moderate to ?ow dermeability. } \\
\text { Contains thin, discontinuous permeable } \\
\text { and water-bearing lenses of sand. }\end{array}$ \\
\hline $\begin{array}{l}\text { Minor } \\
\text { aquifer }\end{array}$ & 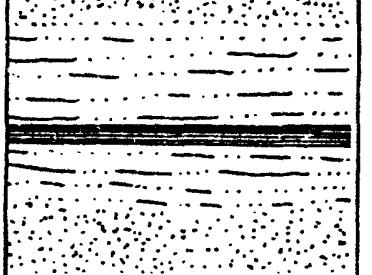 & $\begin{array}{l}\text { Kenai Grcup, interbedded sand, silt, } \\
\text { clay, and coal. Contains water-bearing } \\
\text { strata generally of low permeability. }\end{array}$ \\
\hline
\end{tabular}


of more than 700 feet below land surface near kenai, and slopes upward to within 300 feet of land surface at the northern border of the study area. However, no outcrops are large enough to map at the scale of plate 1. The Kenai Group consists of alternating strata of moderately indurated sand, silt, clay, and lignite; in many respects it is similar to the glacial deposits. No wells are known to produce water from the Kenai Group in the study area; however, south of the study area, wells do produce from this formation. Although the physical characteristics of the Kenai Group are well understood from oil and gas exploration, its water-bearing properties are poorly known.

\section{Unconsolidated Quaternary Deposits}

Unconsolidated deposits in the area are made up of debris remaining from at least three glaciations during the pleistocene Epoch. In addition to drift (a general term for all deposits of glacial origin) derived from these glaciations, there are minor amounts of wind-lajd deposits of Pleistocene age and lake and swamp deposits and alluvium of pleistocene and Holocene (post-glacial) age.

For this report, drift is divided into glacial moraine, glacial drift undifferentiated, outwash-plain, coastal plain, and deltaic deposits; the alluvium is subdivided into terrace, flood-plain, and abandoned-channel deposits. Lake, swamp, and eolian deposits are not mapped because they occur as thin veneers on the above-differentiated sediments.

Not all unconsolidated deposits in the study area can be classified precisely. Localiy, moraine and outwash deposits are intimately associated and are mapped as undifferentiated glacial drift. The morainal deposits are transitional to outwash and shore deposits, which are, in turn, transitional to alluvium. Nevertheless, at most places the unconsolidated 
deposits differ from each other in form, physical characteristics, and water-bearing properties.

The details of the Quaternary history are complex, and the sequence of subsurface sediments has not been firmly established. However, some generalizations can be made. Each time the area was glaciated a succession of till, outwash, alluvium, and estuarine or lacustrine clay and silt beds was laid down. The deeper unconsolidated sediments are predominantly sand, silt, and clay, indicating long periods of land submergence. In general, the coarse, well-sorted sediments are found near the morainal deposits and comprise or lie beneath the terrace, flood-plain, abandoned-channel, deltaic, or outwash-plain deposits.

Ground water in the unconsolidated deposits occurs in the openings between the rock particles; hence, the hydrologic properties of these deposits differ according to particle size and shape, sorting, and packing of the constituent materials. In general, the porosity, permeability, and specific yield of coarse-grained sediments, such as sand and gravel, are high, especially if these materials are well soried. The porosity of fine-grained sediments, such as silt and clay, commonly is high also, but because most of the water in the numerous small pores is bound by molecular forces, these sediments are iairly impermeable and have a low specific yield. Sediments made up of poorly-sorted materiais have a low porosity, permeability, and specific yield, especially if the particles are firmly packed.

\section{HYDROLOGY}

The circulation of the water from the sea through the atmosphere, to the land, and back to the sea is called the hydrologic cycle (fig. 6). Precipitation is the source of frash-water supplies. Of the precipitation that reaches the 
ground, part evaporates, part is stored in lakes and glaciers part runs off directly to streams, and part infiltrates into the soil and rocks. The water that reaches the ground-water bodies moves slowly under gravity toward areas of discharge. Ground-water discharge occurs naturaliy by evapotranspiration or by flow to streams, springs, or to the sea. A major objective of hydrologic studies is to describe the availability and variability of the usable water, which occurs as streamflow, ground water, or lakes.

\section{Streamflow}

Streams in the Kenai-Soldotna area are of two types, glacial and nonglacial; these differ markedly in both their volume and seasonal variability of flow. The Kenai and Kasilof Rivers are glacial streams that derive most of their discharge from the snowfields and glaciers of the Kenai Mountains. Runoff for the Kenai River is 58.4 inches per. year (Cooper Landing station, $p l .2$ ) and for the Kasilof River, 43.9 inches per year (Kasilof station, pl. 2). These rates reflect the high precipitation in the mountains. Numerous small nonglacial streams originate in the Kenai lowlands, an area which has no snowfields or glaciers. Typical of these nonglacial streams is Beaver Creek whose average runoff for 3 years of record has been 6.59 inches. Plate 2 illustrates the general pattern of runoff. Streamflow for ungaged basins was estimated by drainage area-runoff relations and miscelianeous discharge measurements.

The streamflow summaries in this report are based on records from the gaging stations shown on plate 2 . The record from the Kenai River at Cooper Landing, which is outside the area, is included because it is the long-term index station for the Kenai River drainage. Basic data used in these summaries are from "Surface Water Supply of the United States" (U.S. Geological Survey, 1957, 1964, and 
1971b). "Water Resources Data for Alaska" (U.S. Geological Survey, 1967, 1968, 1969, 1970, and 1971a), and "Hydrologic Data of the Kenai-Soldotna Area, Alaska" (Anderson and Jones, 1971).

\section{Variability of Streamflow}

Streamflow is highly variable, not only from day to day but also from year to year. The seasonal and yearly variability of flow and the magnitude and frequency of floods and low flows must be evaluated before the resource can be developed efficiently. These characteristics are illustrated in this report by summary tables, duration curves, low-flow frequency curves, hydrographs of daily or annual flow, and flood-frequency curves.

The general pattern of seasonal runoff is high flows in the spring from snowmelt and in the late summer and fall from rain. In addition, the glacial streams have high flow during the summer coinciding with periods of peak glacial ice melt. Low flows occur mainly during winter and are sustained by ground water in nonglacial stream basins and by outflow from large lakes in the glacial stream basins. Low flow may also occur in nonglacial streams during July and August when evapotranspiration is high during years of low precipitation.

The seasonal and annual variability in streamflow recorded at gaging stations is illustrated on plate 2. The glacial streams have low variability because of the regulatin! effect of lake and ice storage. Individual monthly average flow in these streams is generally within 60 percent of the iong-term monthly average; however, during some individual months, flow of the Kenai River at Cooper Landing has been more than 250 percent of the monthly average. Abnormally high flows have also occurred in October and November as the result of rain storms and ice-dammed iake releases. Yeariy 


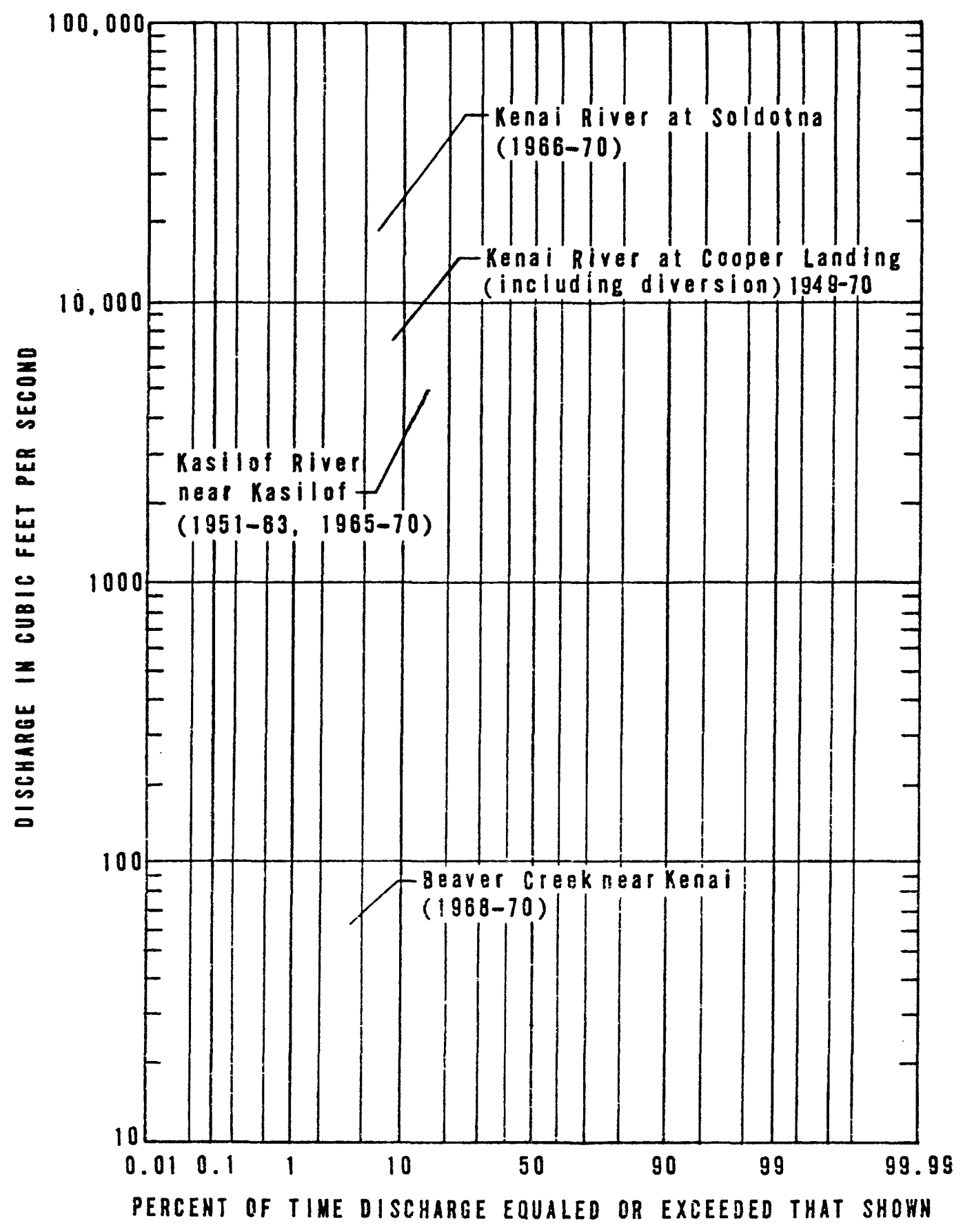

Figure 7.--Duration curves of daily flow, Kenai and Kasilof Rivers and Beaver Creek. 
flow of the Kenai River at Cooper Landing ranges from 73 to 139 percent of the mean annual flow, and yearly flow of the Kasilof River at Kasilof ranges from 79 to 134 percent of the mean annual flow.

Flow-duration curves, giving the percentage of time that certain discharges are equaled or exceeded at the four continuous-record gaging stations, are shown in figure 7 . The slope of a flow-duration curve is a measure of the variability of streamflow. Flat slopes at the lower end of the curves indicate periods of sustained low flow. On the glacial streams, the Kenai and Kasilof Rivers, low flows are sustained by lake storage in Skilak, Kenai, and Tustumena Lakes; on nonglacial streams, such as Beaver Creek, the low flows are sustained by inflow from ground-water sources. On glacial streams, the rate of release from ice, snow, and lake storage controls the seasonal summer and fall high flows. On nonglacial streams, such as Beaver Creek, retention by swamp and ground-water storage restrains the high flows. The steep slope on the upper end of the duration curve for Kenai River at Cooper Landing is a result of periodic high flows from giacier outburst floods. The shapes of the flow-duration curves for the Kenai and Kasilof Rivers and Beaver Creek (fig. 7) indicate that all of these streams have good watersupply potential because of their sustained low flows from natural water stcrage.

\section{Low Flow}

The low-flow characteristics of a stream should be known before the stream is developed as a water supply or utilized for waste disposal. The lowest measured discharges on selected streams are summarized on plate 2. The lowest measured discharges of nonglacial streams range from 0.12 cfs per sq mi. to $0.29 \mathrm{cfs}$ per sq mi., and periods of no flow have been observed on some small basins. For glacial streams, 
the low flow range is from 0.30 to 0.38 cfs per sq mi. However, the Kenai River at Cooper Landing was observed to have no flow on March 27 and 28, 1964, and the Kasilof River at kasilof had flow as low as 19 cfs (which would be equivalent to 0.026 cfs per sa mi. over the entire basin) on April 2 , 1964. Both of these low flows were attributed to the March 1964 earthquake and are not considered in organizing the low-flow discussion.

Low-flow frequency curves show how of ten the average discharge for prestated periods of consecutive days may be expected to equal or to be lower than specified discharges. Such frequency curves indicate the probability of future occurrences of specific discharge values if hydrologic conditions during the base period are representative of long-term conditions and conditions remain unchanged. The 30-day 1owflow frequency curves for the Kenai and Kasilof Rivers are shown in figure 8 . The probability of a specific event occurring is expressed in recurrence intervals at the bottom of the figure. For example, the low-flow frequency curve of the Kenai River at Soldotna shows an annual minimum 30-day average discharge of 1,000 cfs with a 5-year recurrence interval. Therefore, future discharges may be expested to average 1,000 cfs or less over any 30-day period at intervals averaging 5 years. The probability of such an event occurring in any particular year, which is the reciprocal of the recurrence interval, is 20 percent (one chance in five).

The sustained low flows of streams in the Kenai-Soldotna area are demonstrated by miscellaneous low-flow measurements (p1. 2), flow-duration curves (fig. 7), and the 30-day lowflow frequency curves (fig. 8). These indicate that even during drought periods, such as 1968 and 1969 , properly designed systems to develop surface water can provide dependatle water supplies. The Kenai River in particular could be expected to meet all foreseeable water requirements in the 


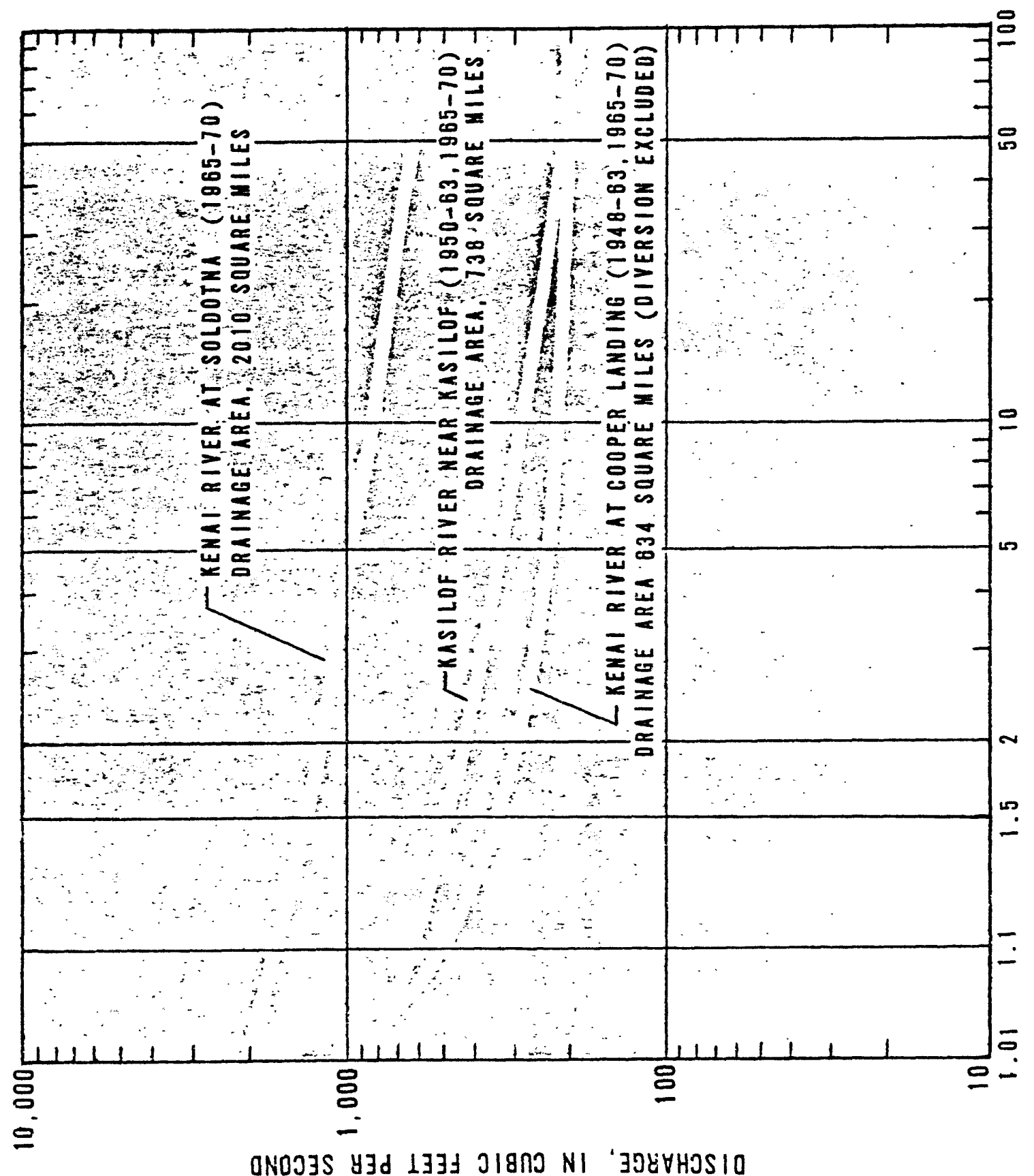

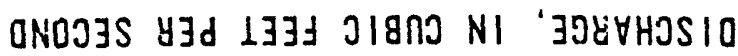


Kenai-Soldotna area, barring unpredictable catastrophic events such as the 1964 earthquake.

\section{Floods}

The flood characteristics of any stream must be considered in the design of structures in its channel or on its flood plain. In the study area, floods on the large glacial streams caused by high rainfall occur generally during late summer and fall. Floods on small nonglacial streams result primarily from snowmelt runoff in the spring. The sudden release of water from glacier-dammed lakes or backwater from ice jams may also cause flooding.

Maximum floods recorded for gaging stations through water year 1970 are presented on plate 2. Highest measured streamflows range from 1.37 cfs per sq mi. on nonglacial streams to 33.9 cfs per sq mi. on glacial streams. Floodfrequency curves [Log Pearson Type III flood-frequency method (Water Resources Council, 1967)] (fig. 9) show the recurrence interval or frequency of floods for the Kenai and Kasilof Rivers for the period of record through 1970. The recurrence interval is defined as the average interval of time within which the given flood will be equaled or exceeded once. From a given recurrence interval, the probability of a flood of a given magnitude occurring in any one year can be estimated. For example, if the recurrence interval of a flood of given magnitude is 25 years, the probability of such a flood in any one year is 4 percent (one chance in twenty-five). Flood magnitudes of selected frequericies for ungaged streams within the study area can be estimated using the method proposed by Childers (1970). Areas along the Kenai River from Soldotna to the mouth that are prone to flooding are delineated in "Flood Plain Information Kenai River" (U.S. Army, Corps of Engineers, 1967). 


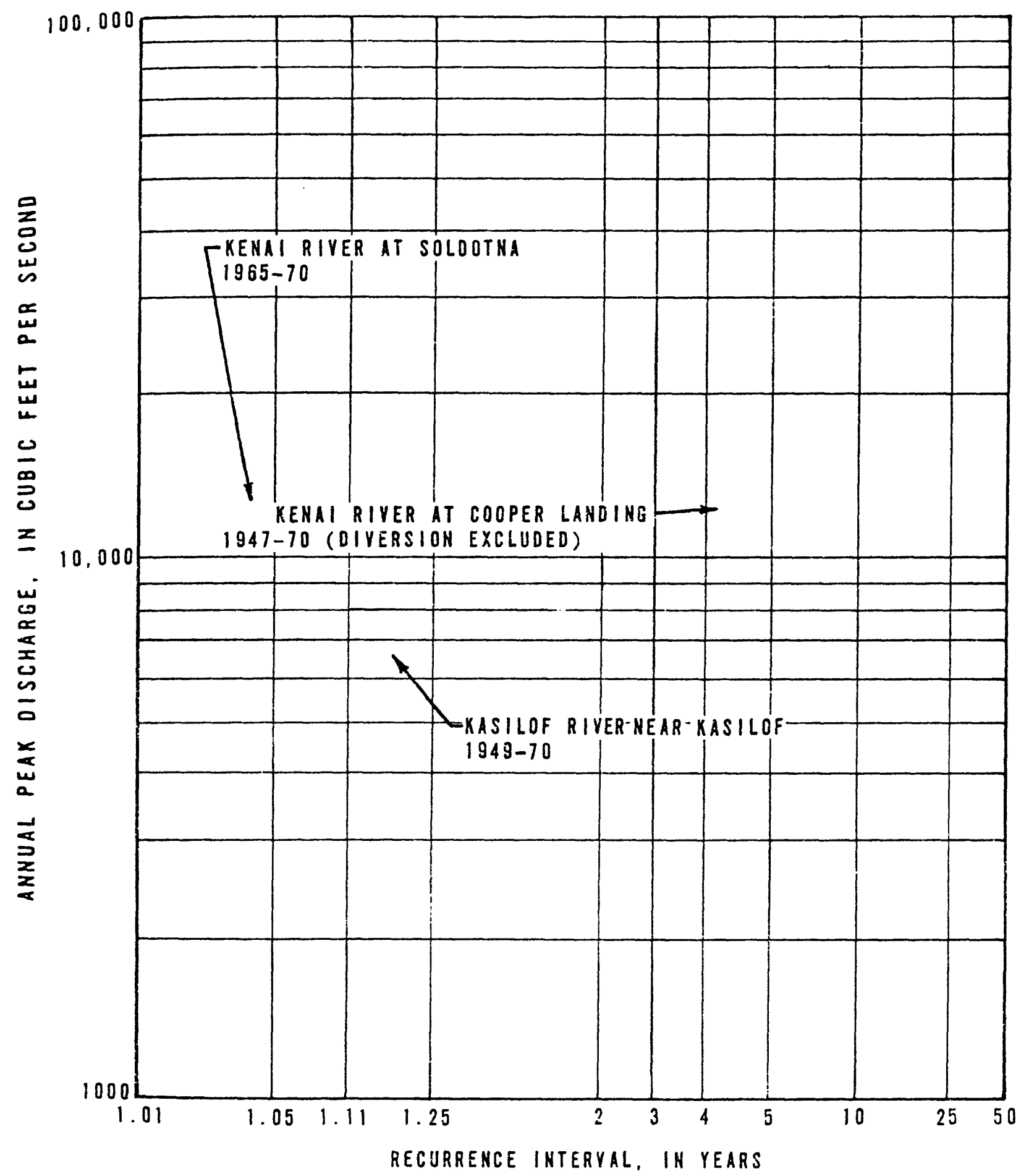

Pigure 9.--Frequency of floods of the Kasiloi River near Kasilof and the Kenai River at Cooper Landing and at Soldotna. 
Natural glacier-dammed lakes form in the upper drainages of the Snow and Skilak Rivers, which are tributary to the Kenai River (tabie 2). The natural storage release of water from these lakes causes flooding, such as experienced when glacier-dammed lakes emptied in the Snow River basin in September 1967 and in the Skilak River basin in January 1969.

\section{$\underline{\text { Lakes }}$}

The numerous lakes in the study area form an important part of the water resource. The lakes are natural reservoirs in which water is temporarily stored; their net effect is to reduce peak streamflows and to increase low flows. Also, the lakes of the Kenai-Soldotna area are valuable in terms of scenic and recreational attraction.

Most lake basins of the Kenai-Soldotna area are glacial in origin and are distributed throughout the areas mapped as glacial moraine and drift ( $p 1$. 1). Many lakes in the drift occupy depressions that extend below the ground-water level, and the fluctuation of the lake level is similar to the fluctuation of adjacent water-table ground-water levels.

The lakes in glacial moraines are commonly perched, that is, their water levels are generally above the regional ground-water tabie. Thus, adjacent lakes may have widely different water levels.

From 1967 to 1970, water levels in lakes dropped. The magnitude of these drops was documented from discussions with local residents, photographic comparisons, and field surveys. The field surveys included measurement of the elevation difference between the water surface and the highest established beachline (fig. 10). 
Table 2.--occurrence and magnitude of Snow River outburst floods for Kenai River at Cooper Landing.

[After Post and Mayo, 1971 and surface water records]

\begin{tabular}{|c|c|c|}
\hline $\begin{array}{c}\text { Date } \\
\text { (caiendar year) }\end{array}$ & $\begin{array}{l}\text { Maximum gage height } \\
\text { (feet) }\end{array}$ & $\begin{array}{c}\text { Maximum discharge } \\
\text { (cubic feet per second) }\end{array}$ \\
\hline $\begin{array}{l}1947 \\
1948, \\
1949, \text { oct. } 28 \\
1950, \\
1951, \text { Nov. } 18 \\
1952, \\
1953, \text { Dec. } 17 \\
1954, \\
1955, \text { } \\
1956, \text { Oct. } 30 \\
1957, \\
1958, \text { Oct. } 17 \\
1959, \\
1960 \\
1961, \text { Oct. } 8 \\
1962, \\
1963, \\
1964, \text { Sept. } 24 \\
1965, \\
1966, \\
1967, \text { Sept. } 1 \\
1968, \\
1969 \\
1970, \text { Sept. } 23 \\
1971\end{array}$ & $\begin{array}{c}\text { No outburst } \\
\text { No outburst } \\
13.55 \\
\text { No outburst } \\
7.53 \\
\text { No outburst } \\
6.56 \\
\text { No outburst } \\
\text { No outburst } \\
8.11 \\
\text { No outburst } \\
8.44 \\
\text { No outburst } \\
\text { No outburst } \\
10.50 \\
\text { No outburst } \\
\text { No outburst } \\
\\
14.30 \\
\text { No outburst } \\
\text { No outburst } \\
\\
\text { No outburst } \\
\text { No } 25 \\
\text { No outburst } \\
\text { 13.52 } \\
\text { No outburst }\end{array}$ & $\begin{array}{c}\overline{-} \\
11,600 \\
- \\
6,250 \\
\overline{-} \\
4,420 \\
\overline{-} \\
7,310 \\
\overline{-} \\
8,30 \\
- \\
14,000 \\
- \\
14,200 \\
\overline{-} \\
21,500 \\
- \\
12,100 \\
-\end{array}$ \\
\hline
\end{tabular}

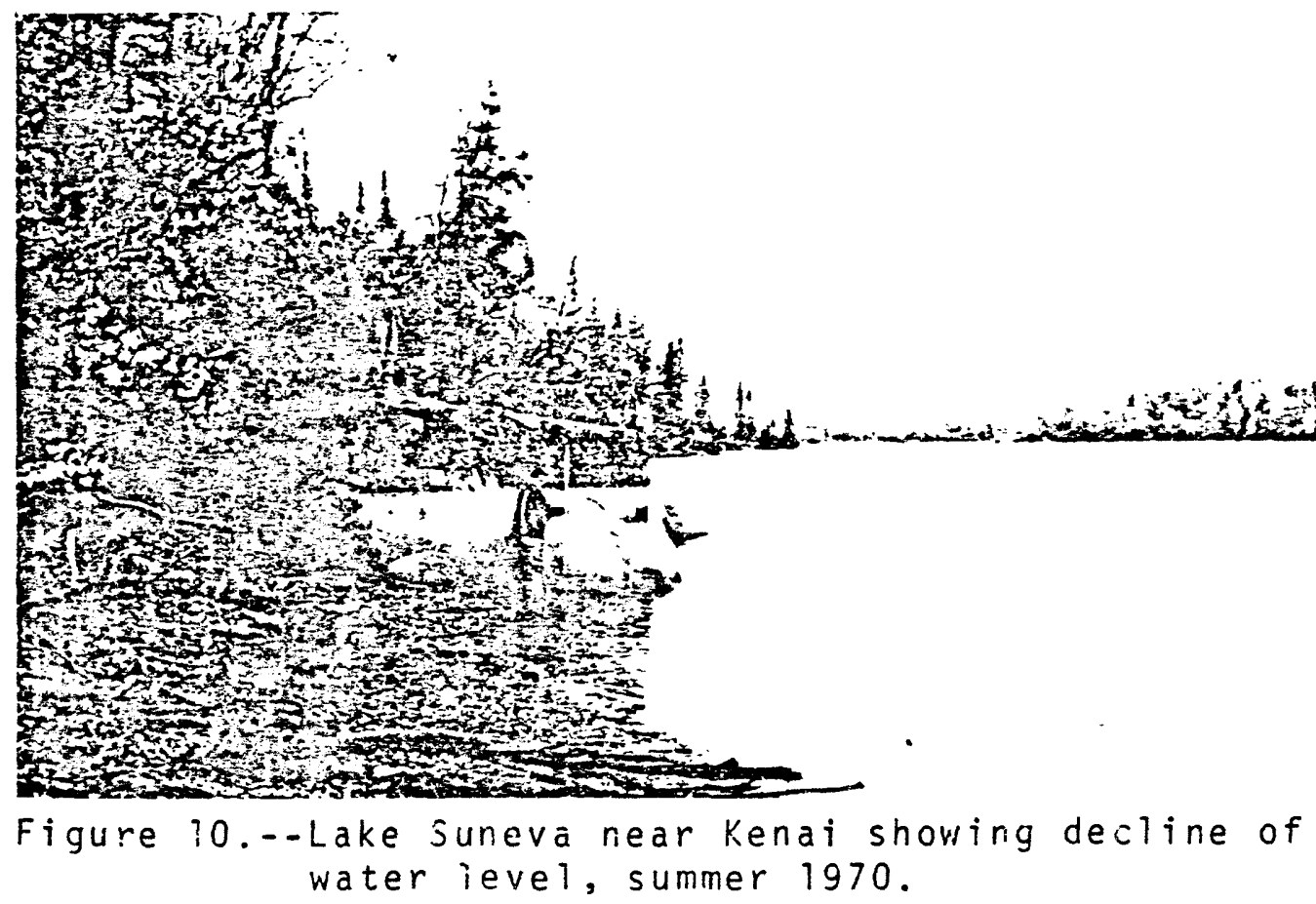


Results of the lake survey did not indicate a definite pattern of lake-level declines. The greatest declines were observed in closed basins in drift deposits; the maximum decline of 6 feet was measured in three lakes near North Kenai industrial plants $(p 1,2)$. Minimum declines were observed in perched lakes in the morainal deposits and in lakes interconnected by streams in the drift deposits. Lake levels in perched lakes may have been lower during 1969; but, during the normal rainfall of 1970 , the perched lakes would be expected to recover faster than the lakes interconnected with the water-table aquifer because little inflow would be lost to ground-water recharge. Lakes interconnected by streams generally exhibited a constant water level during the drought period; presumably the lake levels were maintained by surface-water inflow. The drought conditions of 1968 and 1969 are believed to be the principal cause of lake-level declines.

\section{Ground Water}

The Ground-Water Reservoir

In the Kenai-Soldotna area, ground water occurs under water-table and artesian conditions. The general occurrence of ground water is summarized on plate 1 . A water-table aquifer generally occurs throughout the area. It ranges in thickness from about 5 feet to 100 feet and, in most areas, yields at least modest supplies of water to wells. The artesian aquifers underiie confining units of clay, silt, and poorly sorted clayey gravel ranging in thickness from 20 to 100 feet. The movement of water through the confining units is slow because the permeability is low. The artesian aquifers range in thickness from a few feet to 100 feet and are absent in some places. They are the principal sources of ground water in the area and are predominantly fine sand interbedded with coarse sand and gravel and beds of clay or silt. The most productive wells are completed in lenses of 
coarse sand and gravel, which are difficult to locate. Although not extensive, the lenses intersect or apparently are interconnected, forming a hydraulic artesian system of considerable areal extent and thickness.

\section{Recharge}

Recharge to aquifers of the study area is from infiltration of rain and snowmelt, seepage from lakes, and groundwater underflow from outside the study area. Areas of recharge are shown in figure 11.

The principal areas of recharge are the permeable outwash sediments, and the areas of minor recharge are the low-permeability glacial moraines (pl. 1). Recharge from local infiltration of precipitation and snowmelt is estimated to range from 4 to 15 inches per year.

The rate of ground-water underflow entering the study area from the east is not known. However, it is not considered to be high because the gradient across the Kenai lowlands and the permeability of the underlying glacial deposits are both low.

\section{Movement}

The general direction of ground-water movement is from points of reciarge to points of discharge. The shape and slope of the potentiometric surfaces are controlled by the topography, local differences in the permeability and thickness of the aquifers and by variations of recharge and discharge. The position of the water-table or artesian potentiometric surface is usually mapped by measuring water levels in weils. However, in the Kenai-Soldotna area the welis are too few and too widely spaced to permit accurate mapping. In general, the water-table surface in this area is considered to be a subdued replica of the land-surface 


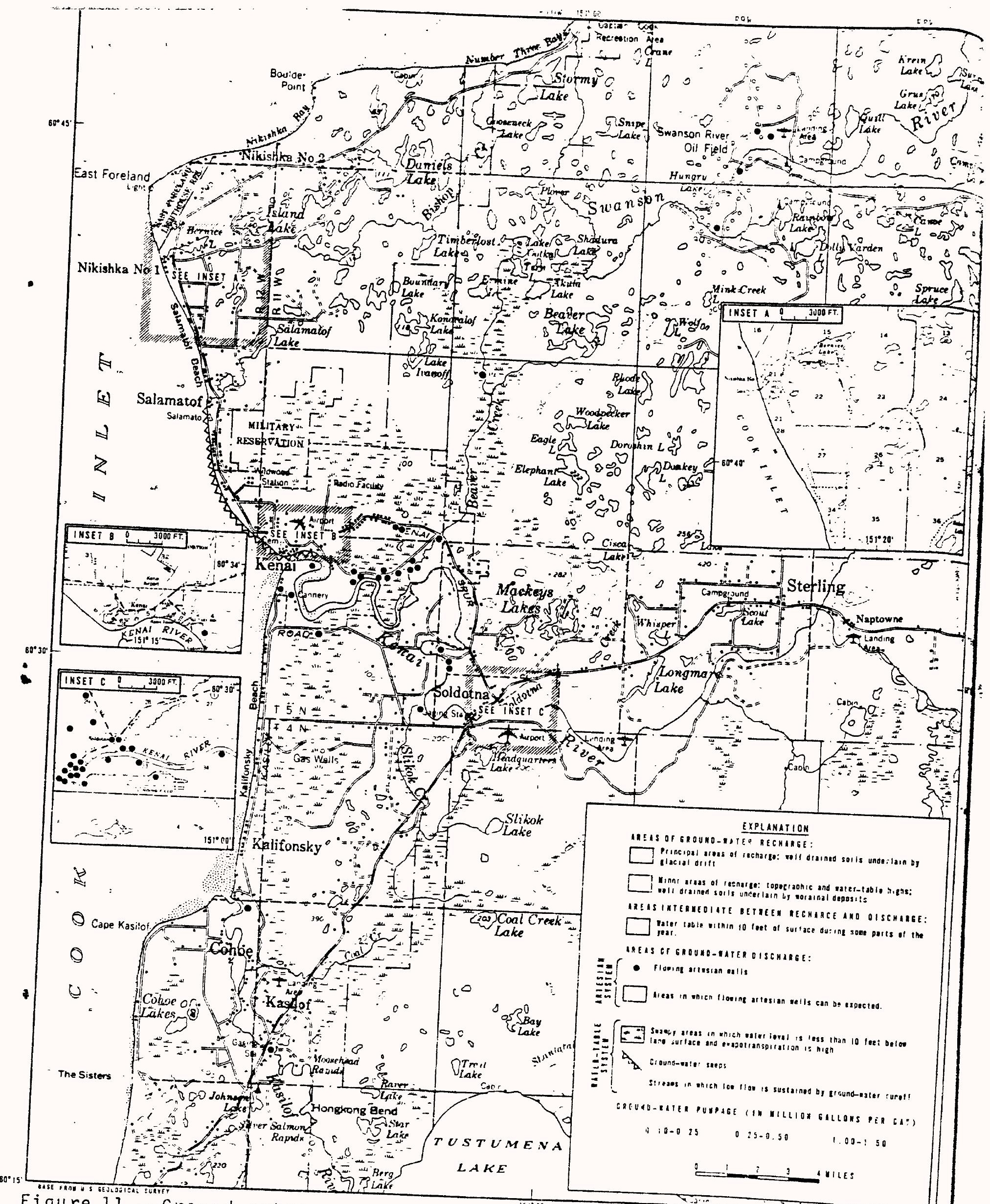

Figure 11.--Ground-water recnarge and dischio 
topography and is as much as 100 feet below the surface of hilltops and is at or near the land surface in the lowlands. Because the Kenai-Soldotna area has little relief, the water table has a gentle gradient and the rates of water movement are low. Swampy areas exist where the water-table gradient is nearly flat.

The potentiometric surface (level to which water will rise) of the artesian aquifers is poorly defined and has not been mapped. In general, the potentiometric surface is similar to the water-table surface in areas of recharge. But in areas of discharge, such as the area of flowing artesian wells in figure 11 , the artesian potentiometric surface is at a higher elevation than the water table. Where the watertable and potentiometric surfaces are at different elevations, vertical flow through the confining unit between the two aquifers may occur.

\section{Dischàrge}

Ground water is discharged both naturally and artificially. It is discharged naturally from water-table aquifers through seeps or springs, as ground-water runoff to streams, and by evaporation and transpiration, and from artesian aquifers by possible vertical leakage through the confining beds or by submarine discharge into Cook Inlet. Ground water is discharged artificially from artesian or water-table aquifers by pumping and from water-table aquifers by drainage ditches.

A major area of discharge is illustrated in figure 11. Numerous seeps occur along the sea cliffs near Kenai where impermeable clay crops out at the surface and where water draining from the water-table aquifer is forced to the surface. The discharge along this seepage front is estimated to be about $i$ cfs per mile of beach. Springs aiso discharge along the Kenai and Xasilof Rivers; however, they have not been mapped in figure 11 . 
Natural discharge from water-table aquifers to streams is defined as ground-water runoff. During dry periods when surface runoff is minimal, differences between streamflow at two or more points along a stream indicate ground-water discharge or recharge. Those streams in the Kenai-soldotna area having low flows sustained by ground-water runoff are illustrated in fiqure 11. Measurements on Beaver Creek during July 1969 indicated an increase of 16 cfs (ground-water dis. charge) along 7 miles of channel above the gaging station, and on the Swanson River during July 1968, an increase of 24 cfs along 16 miles of channel (fig. 12). Measurements during November 1967 along the Kenai River, including the tributary inflow, did not indicate any differences that were significant within the accuracy of the measurements.

Where ground-water runoff can be separated from surfacewater runoff in a hydrograph of total streamflow, it is possible to determine the mean annual ground-water runoff from a basin. Using a separation technique, an estimate of the ground-water runoff during 1969 and 1970 from the Beaver Creek streamflow record was determined (fig. 13). The hydrograph separation was made by developing a reiationship between mean daily ground-water runoff, measured stream discharge during dry periods when surface runoff is minimal, and mean daily ground-water stage at one observation well near Beaver creek gaging station. This plot of ground-water runoff and stage is used to determine the proportion of ground-water runoff in the total siream discharge during wet periods of surface-water runoff. This separation technique is similar to the method developed by Meinzer and Stearns (1929, p. 127), who used many observation wells in a basin to compute an average ground-water stage. However, in this study there are not enough welis for a meaningful average water-level stage; therefore, the record from one good observation well is used as an index. 


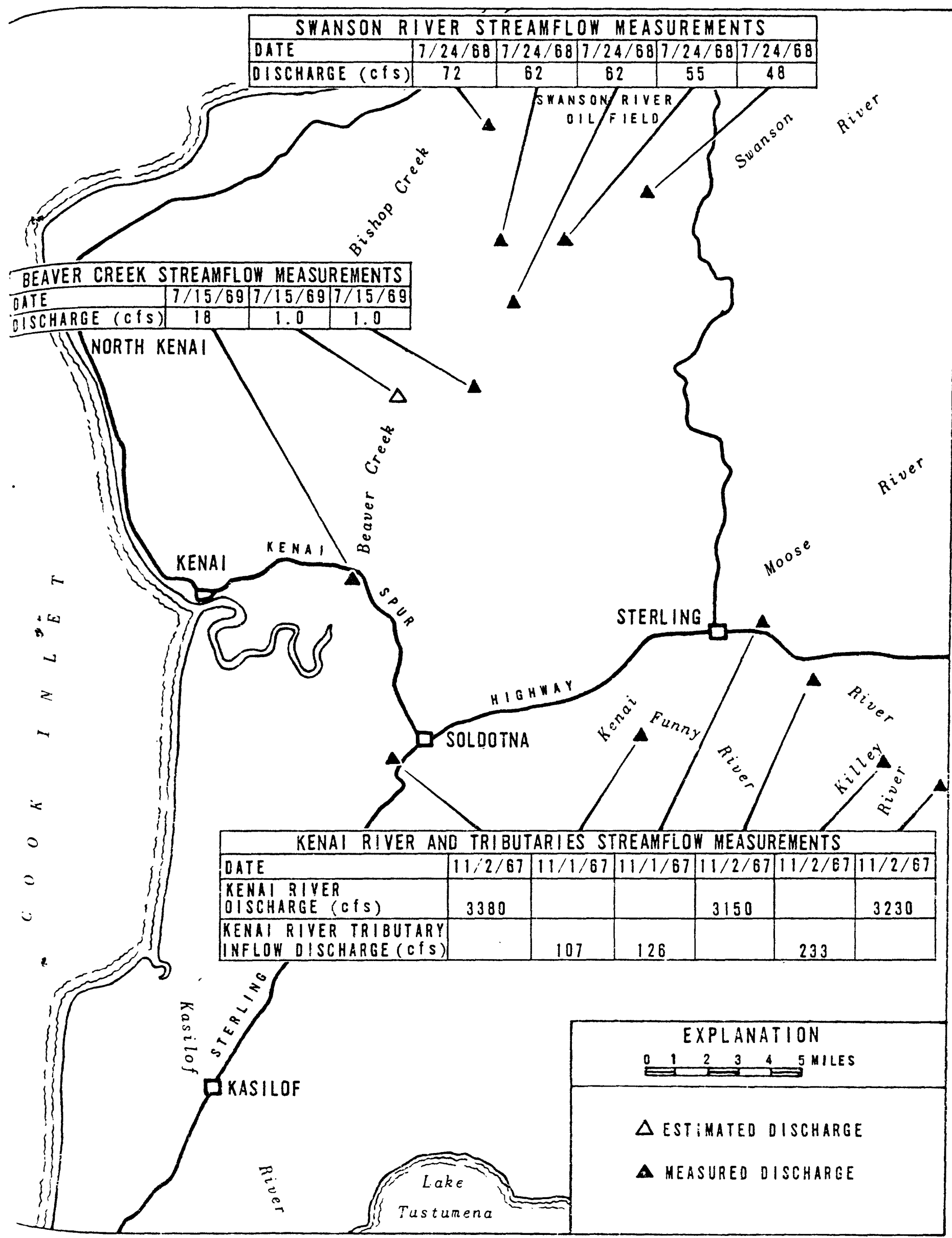

Figure 12.--Comparable discharges at se iected sites on rivers in the Kenai-Soldotna area. 


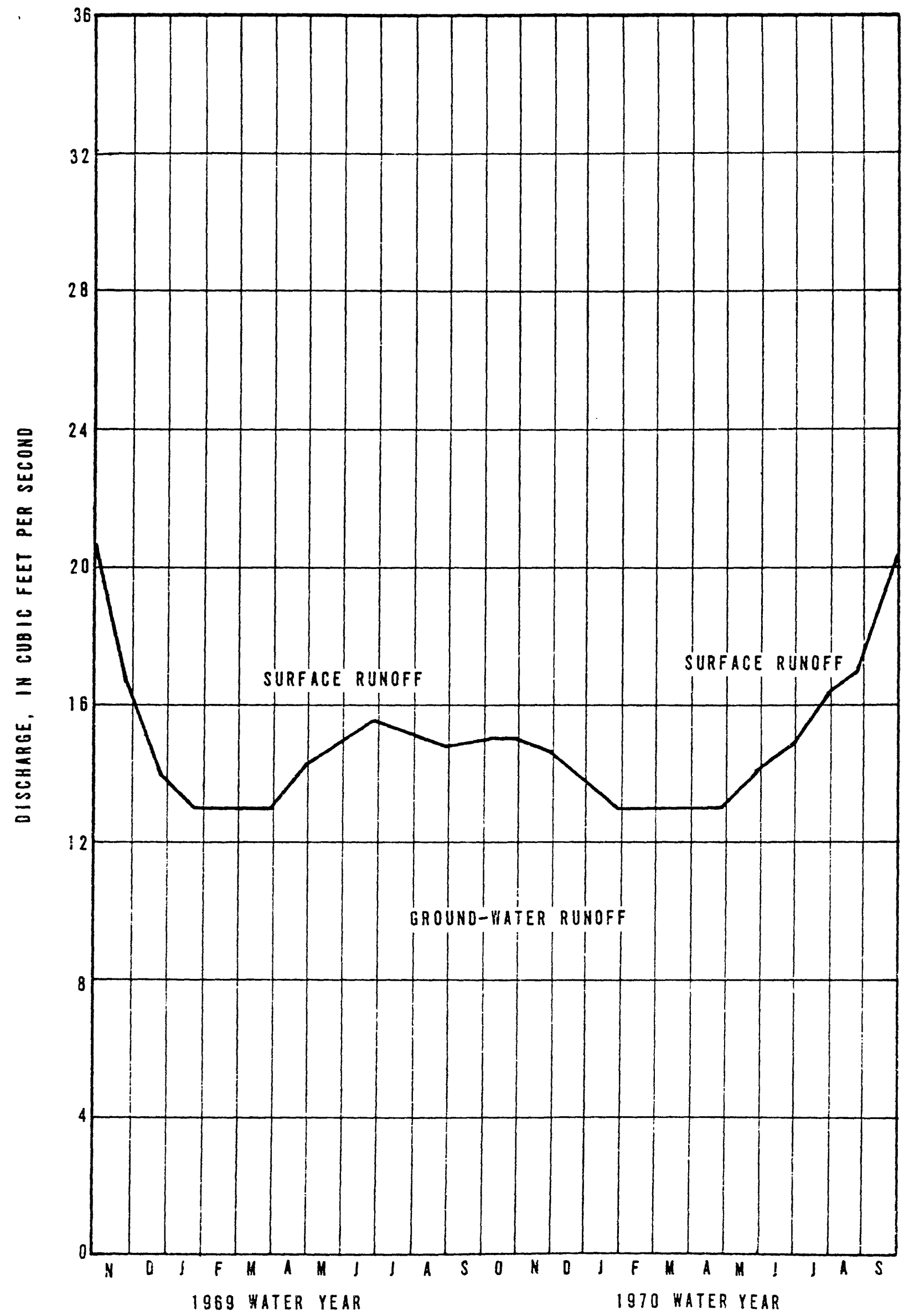

Figure 13.--Beaver Creek discharge showing separation of the monthly surface runoff and ground-water runoff components. 
For the 2 years of record, the average ground-water discharge was estimated to be about 15 cfs. The area of Beaver Creek basin above the gage is 50 square miles, so the average annual ground-water runoff was estimated to be about 4 inches.

Transpiration of ground water occurs wherever plants grow and the water table is near the surface. Also, evaporation of ground water occurs wherever the water table is at or near the surface. The combined process of transpiration and evaporation is termed evapotranspiration. The swampy areas shown in figure 11 are the principal areas of groundwater discharge by evapotranspiration in the study area. Evapotranspiration from ground water for the Kenai-soldotna area is not known; however, it is probably a significant proportion of total evapotranspiration, which is estimated to average 5 to 10 inches per year.

Discharge from the artesian aquifers may occur as upward vertical leakage in the areas of flowing artesian wells ifig. $11)$ or in other places where the potentiometric surface is higher for the artesian aquifer than for the water-table aquifer. The rate of vertical leakage would depend on both the hydraulic gradient between the artesian and water-table aquifers and on the permeability of the confining sediments.

Based on a projected extension of the artesian aquifers of the North Kenai area seaward, ground water is probably a?so discharged by submarine springs in Cook Inlet. The greatest submarine discharge probably is near North Kenai.

The total pumpage from wells is small compared to natural discharge. In 1970, the total ground-water pumpage in the Kenai-soldotna area was estimated to be $3.4 \mathrm{mgd}$. Of this total, $2.8 \mathrm{mgd}$ was from artesian aquifers and $0.6 \mathrm{mgd}$ was from water-table aquifers. A small but undetermined amount of shallow ground water is discharged by a drainage system near the Kenai Airport. 


\section{Fluctuations of Water Levels}

Water-level fluctuations are related to differing rates and amounts of recharge and discharge, to changing external loading caused by tides, by variation in atmospheric pressure, and to natural forces such as earthquakes. Figures 14 and 15 show typical well hydrographs from the Kenai-Soldotna area that show the effects of either precipitation or industrial ground-water pumpage. The locations of these wells are shown on plate 1 .

The hydrographs for water-table wells (wells 10646 and 10155) show marked seasonal fluctuations (fig. 14). The highest water levels are in August, September, and October, which is the rainy season. After the ground freezes in october recharge is reduced, and the water levels decline generally reaching their lowest position in February or March. The first appreciable snowmelt in the spring is accompanied by a sharp rise in the water table, indicating that the ground-water reservoir is being replenished. Declining water levels in water-table aquifers during periods of heavy industrial pumpage in 1968-70 cannot be correlated with pumpage because of the general drought conditions during the period. However, well 10613, a water-table well near the industrial wells, declined during 1970 and did not respond to the recharge from precipitation in the fall of 1970 .

The water levels in artesian aquifers do not respond to precipitation as rapidly as those in water-table aquifers (fig. 15). The hydrograph of artesian well 10001 generally shows a rising water level during years of normal precipitation, but the water level does not respond to individual storms. Short-term periods of ground-water decline caused by pumpage are indicated by the hydrograph of well 10001. Long-term periods oi declining artesian ground-waier levels associated with large ground-water withdrawals by industrial 

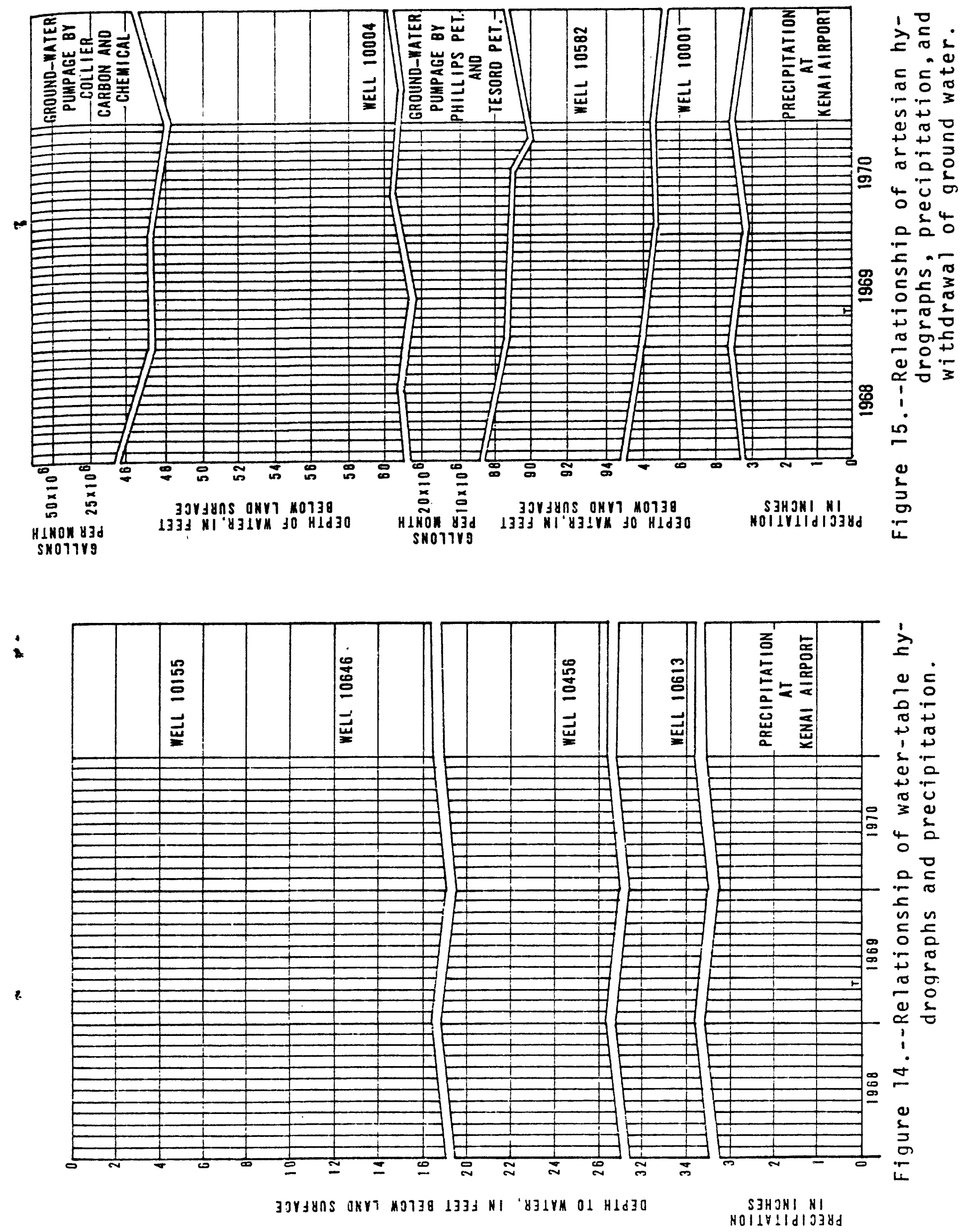
pumping are indicated by the hydrographs of wells 10004 and 10582. Water levels in the artesian aquifer near North Kenai have been generally declining since industrial pumpage began.

\section{Ground-Water Storage}

Water-level fluctuations are an index to seasonal and long-term changes in ground-water storage. A rising water table indicates recharge and an increase in the amount of ground water in storage; conversely, a declining water table indicates discharge and a decrease in the amount of ground water in storage.

To analyze the significance of ground-water level changes, it is necessary to know the storage coefficient of the aquifer. The storage coefficient is defined as the volume of water an aquifer releases from or takes into storage per unit surface area of aquifer per unit change in head. The storage coefficient of water-table aquifers averages about. 0.2. This means that for a 5-foot drop in ground-water level, there is effectively a 1 -foot ( 5 feet $\times 0.2=1.0$ foot) 1 oss of water.

In the Kenai-Scldotna area, the water level in the watertable aquifer dropped an average of 4 feet from its high in the fall of 1967 to its low late in the winter of 1970 .

During 1968 and 1969 , the precipitation deficiency was approximately 18 inches. The 4-foot ground-water decline multiplied by a storage coefficient of 0.2 equals an actual water loss from storage of 0.8 feet, or about 10 inches. This 10-inch loss from ground-water storage is expected considering the precipitation deficiency and consequent reduction in groundwater recharge.

The storage coefficient of most artesian aquifers ranges from about 0.00001 to 0.001 and probably averages about 0.0001 for artesian aquifers in the Kenai-soldotna area. 
This storage coefficient is very small, and the amount of water taken from or added to storage per unit change in water levels under water-table conditions is generally many times larger than under artesian conditions. For example, a 30-foot decline in the water level of the water-table aquifer in the Kenai-soldotna area represents about 6 feet of water loss, but the same decline in the artesian aquifer, with a storage coefficient of 0.0001 , would represent about 0.003 -foot water loss.

\section{Ground-Water Development}

Ground water at present is the primary source of water supplies in the Kenai-Soldotna area. Development of ground water has ranged from wells to provide small domestic supplies to those for industrial or municipal supplies requiring several hundred gallons per minute. The developer of a domestic suppiy is restricted to obtaining a suitable supply at the site of intended use, al though he does have some flexibility in buying land where the chances of developing an

: adequate supply are good. The developer of larger supplies is less restricted because funds available usually allow him, if necessary, to explore for water at some distance from points of intended use. Geohydrologic conditions are the principal control in the development of water supplies.

Plate 1 summarizes the general water-bearing characteristics of the sediments, and the following discussion summarizes the status of domestic and industrial-municipal water development.

Domestic Supplies

Domestic wells have been drilled in most inhabited parts of the study area. Most wells that are of sufficient depth to allow for water-level declines during drought yield enough water for normal nousehold use. In the study area, the potential domestic user of ground water is corsequentiy most concerned with well depth. Figure 16 is a frequency distribution of the domestic weli deptris; most are less than 100 feet deep. 


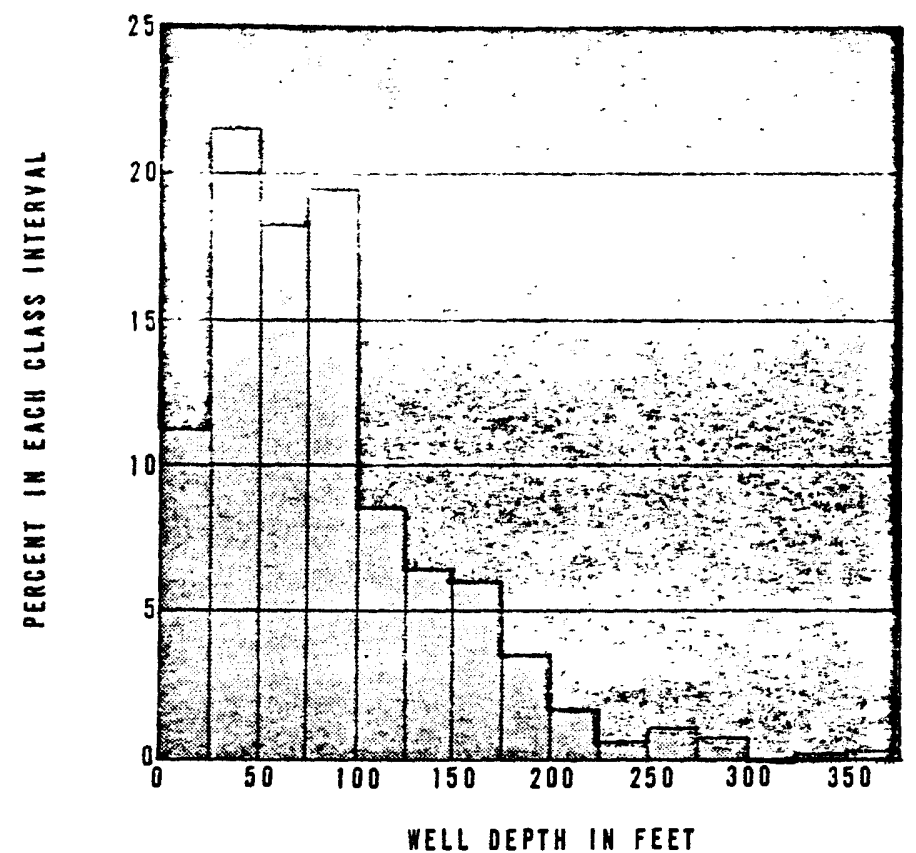

Figure 16.--Frequency distribution of domestic well depths in the Kenaj-Soldotna area.

Throughout the area some wells are described as dry because they do not provide sufficient water for modest household demand. Although the record of dry holes is incomplete, probably less than 5 percent of the drilied wells are unsuccessful. These result from poor well construction or from drilling at sites having unfavorable geohydrologic conditions.

Industrial and Municipal Supplies

The developmert $t$ of large supplies of ground water requires detailed information on the geology and hydrology of the sediments, on ground-water availability of the area, and on the effects of ground-water withcrawal on the hydrologic system. The state of knowledge concerning these items of information in North Kenai, Kenai, Beaver Creek valley, and Soldotna is discussed in the following section. 
North Kenai--The major source of ground water in North Kenai is an artesian aquifer ranging in depth from 100 to 300 feet below land surface. This aquifer is predominately medium sand containing lenses of gravel. The gravel lenses have the greatest potential for ground-water development, but they are discontinuous and their location is unpredictable. In general, the coarsest material and the most numerous gravel lenses of the artesian aquifer are found in the drift near the moraines at East Foreland ( $p 1$. 1). Toward the south, the sediments are finer, the gravel lenses less numerous, and the depth to productive aquifers is greater (p1. 1).

Yields from wells in the artesian aquifer of North Kenai range from 200 to $1,400 \mathrm{gpm}$. Transmissivity, determined from aquifer tests, ranges from 1,300 to $20,000 \mathrm{ft}^{2} \mathrm{day}^{-1}(10,000$ to 150,000 gpd per foot). The transmissivity $(T)$ is the rate at which water at the prevajling temperature is transmitted through a unit width of the aquifer under unit hydraulic gradient. Hydraulic conductivity of the aquifer material is in the range of 54 to $330 \mathrm{ft} \mathrm{day}^{-1}(400$ to 2,500 gpd per square foot). Hydraulic conductivity $(k)$ is the rate at which water of the prevailing temperature is transmitted through a unit area of material under unit hydraulic gradient. The transmissivity is equal to the average hydraulic conductivity times the saturated thickness of the aquifer.

The areal hydraulic characteristics of the artesian aquifer are complex. Results of test drilling and aquifer tests suggest that the major aquifers are lenticular and that aquifer transmissivity changes over short distances. Also, the semiconfining beds of the artesian aquifer appear to be leaky. Data from aquifer tests, such as the one for the Collier Carbon and Chemical production well 10602 , October 8 , 1971 (fig. 17), indicate that water is derived from storage within and leakage through the semiconfining beds. Data from aquifer tests responding to these types of conditions may be 
analyzed by a method that utilizes the modified theory of leaky aquifers (Hantush, 1960). Results of this method of analysis provide estimates of the leakage and storage parameter $(\beta)$ of the semiconfining beds and transmissivity and storage coefficient of the aquifer. The leakage and storage parameter $(\beta)$ is a complicated term characterizing the thickness, hydraulic conductivity, and storage coefficient of the semiconfining beds. However, data from the Collier Carbon and Chemical test are not adequate to determine a unique solution for the leakage and storage parameter $(B)$, or of the individual components of this parameter. An average or best fit for $\beta$ is used to calculate the transmissivity and storage coefficient. The same data could be fit to a range of $B$ curves resulting in a corresponding range in aquifer characteristics.

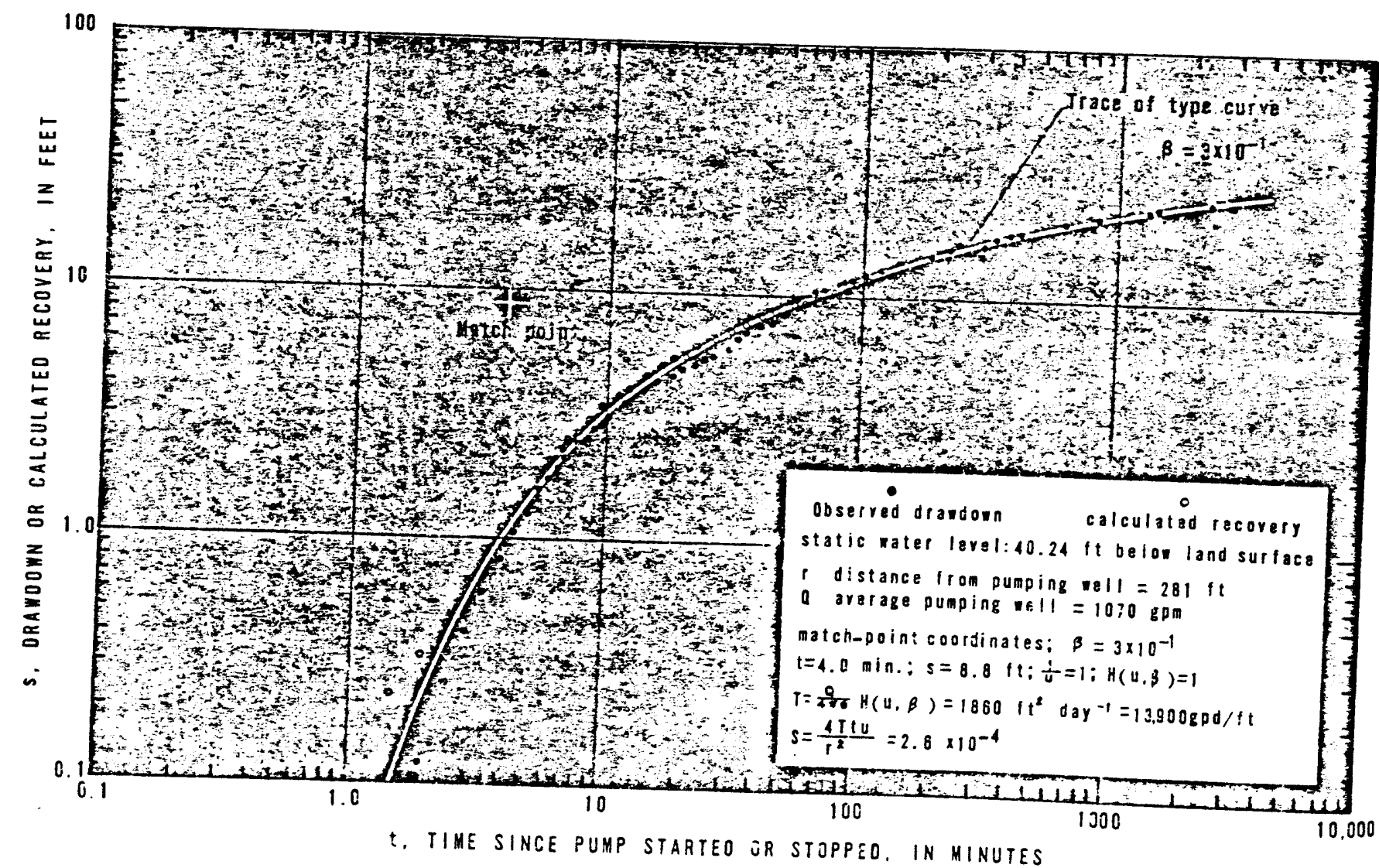

Figure 17.--Aquifer test of Collier Carbon and Chemical production well
(well 10502 ), October 8, 1971 . 
A water-table aquifer occurs in North Kenai where depth to water ranges from 20 to 60 feet below land surface and aquifer thickness ranges from 10 to 60 feet. Wells tapping the aquifer yield from 50 to $1,000 \mathrm{gpm}$; however, this aquifer is not generally developed by industry because the ground water contains a high concentration of iron.

The North Kenai ground-water system is poorly defined because of the early stage and distribution of development and because the sediments are complexly interbedded. Preliminary estimates of the ground-water availability are based upon assumed basin boundaries (fig. 18) corresponding with either surface-water drainage or known impermeable boundaries, and upon meager water budget data.

Mean annual recharge to the North Kenai system is estimated to be greater than $6.5 \mathrm{mgd}$. This estimate was derived by multiplying the unit ground-water runoff value for Beaver Creek basin by the area of the North Kenai ground-water system and by assuming that average ground-water recharge is at least equal to ground-water runoff during drought conditions. This is believed to be a conservative estimate of the total recharge because: (1) The assumed value for groundwater runoff in Beaver Creek basin is probably low because it is based on records from 2 years of below-normal precipitation (1969 and 1970), and (2) recharge in the North Kenai area is probably greater than in swampy Beaver Creek basin with its relatively high evapotranspiration.

Recharge to the North Kenai artesian aquifer is by vertical leakage from the water-table aquifer and by aroundwater underflow from the east. 


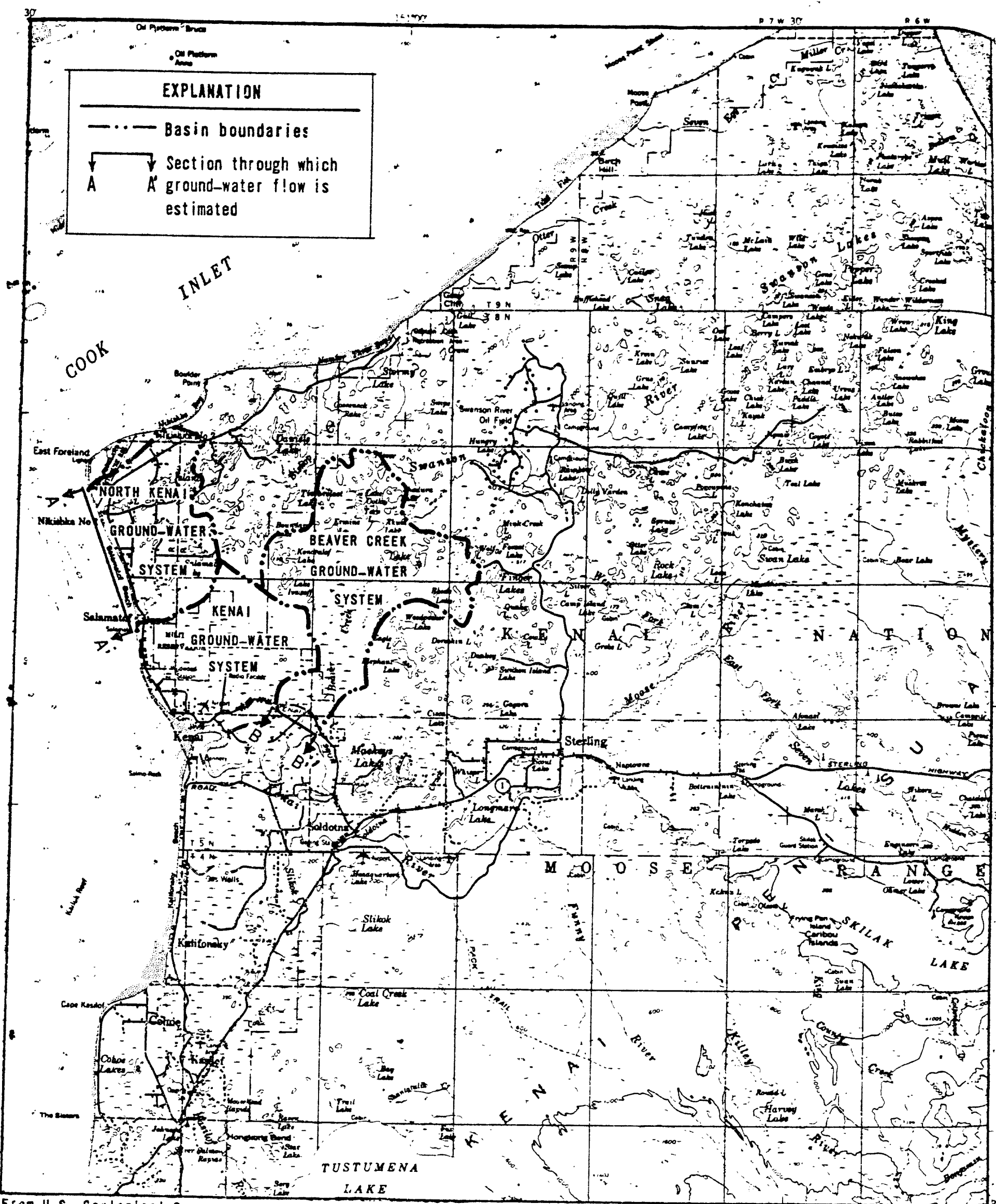

From U.S. Sojloglical Surves 5

Kenal Quadranglo (1969)

CONTOUR INTERVAL :OO FEET

DATUM IS MEAN SEA FOVEL CONTOURS

Figure i8.--Ground-water basins. 
The following assumptions are made to estimate the discharge (Q) from the North Kenai artesian system to Cook Inlet through the 6-mile profile A-A' (fig. 18): (1) Average transmissivity $(T)$ is $2,680 \mathrm{ft}^{2} \mathrm{day}^{-1}(20,000 \mathrm{gpd}$ per foot) and (2) the slope of the ground-water surface (I) is 60 feet per mile through the profile. The quantity of discharge is calculated from the formula:

$$
Q=T I W
$$

where $Q, T$, and $I$ are defined above, and $W$ is the width of flow across profile $A-A^{\prime}$ in feet.

$$
\begin{aligned}
& Q=T I W \\
& Q=2,680 \mathrm{ft}^{2} \mathrm{day}-1 \times \frac{60 \mathrm{ft}}{5,280 \mathrm{ft}} \times(6)(5,280) \mathrm{ft} \\
& Q=7 \mathrm{mgd}, \text { or } 5,000 \mathrm{gpm}
\end{aligned}
$$

During 1970 , North Kenai industrial ground-water pumpage averaged $2.4 \mathrm{mgd}$. Industrial pumpage increased rapidly between 1968 and 1970 ( $f$ ig. 19), but this pumpage is not expected to increase markedly from the 1970 rate until new industry locates in Norch Kenai.

At the present rate of ground-water withdrawal, it is probable that the North Kenai ground-water basin is underdeveloped. Ground-water pumpage is less than estimated recharge and excess water is being discharged to cook Inlet. - However, the effects of pumpage can be observed.

The most notable effect of these ground-water withdrawals has been a decline in artesian water levels (fig. 15). Changes in water levels correlate with changes in rates of pumping. Drawdown approximated 11 feet in observation wel1 10004, which is 2,000 feet from the collier Carbon and Chemical production we 117 ; however, during periods of reduced pumpage, the we 11 recovered to within 5 feet of the original water level. 


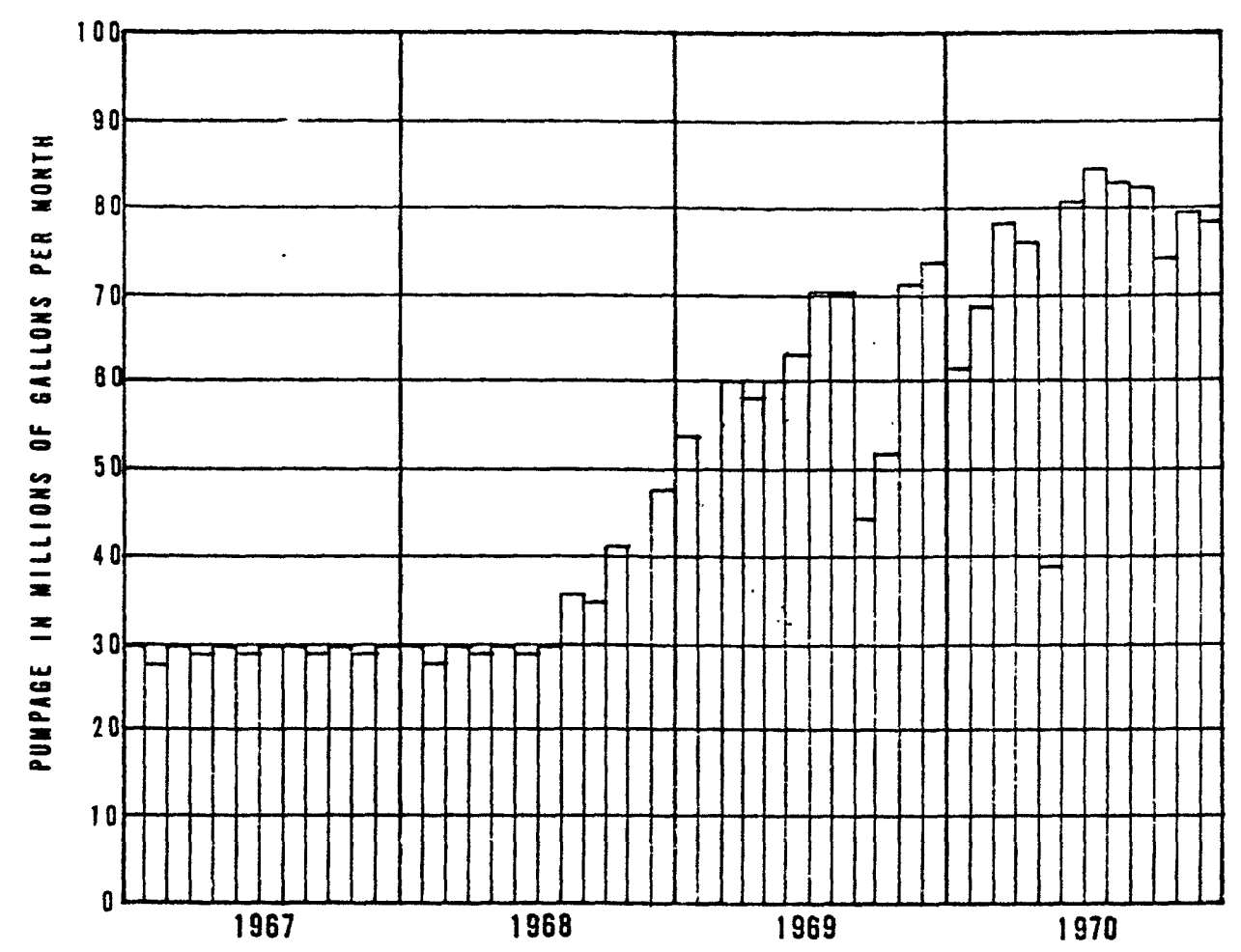

Figure 19.--North Kenai industrial ground-water pumpage.

Water levels have not stabilized, indicating that near the pumping wells more water is being pumped than is being replenished by natural or induced recharge. Although the water level dropped approximately il feet in well 10004 in the first 2-1/2 years (1968-70), the rate of water-level decline decreases each year. Assuming no significant change of ground-water withdrawal from North Kenai, no change in the rate of natural or induced recharge, and no significant variation in the regional hydraulic characteristics of the aquifer, it would probably take another 25 years to double this drawdown (fig. 20). More likely, however, the rate of induced recharge will increase as the cone of depression expands over an increasingly larger area. Eventually the induced recharge wiil be equal to the ground-water pumpage and water levels will either stabilize or fluctuate in response to variations in natural recharge. 


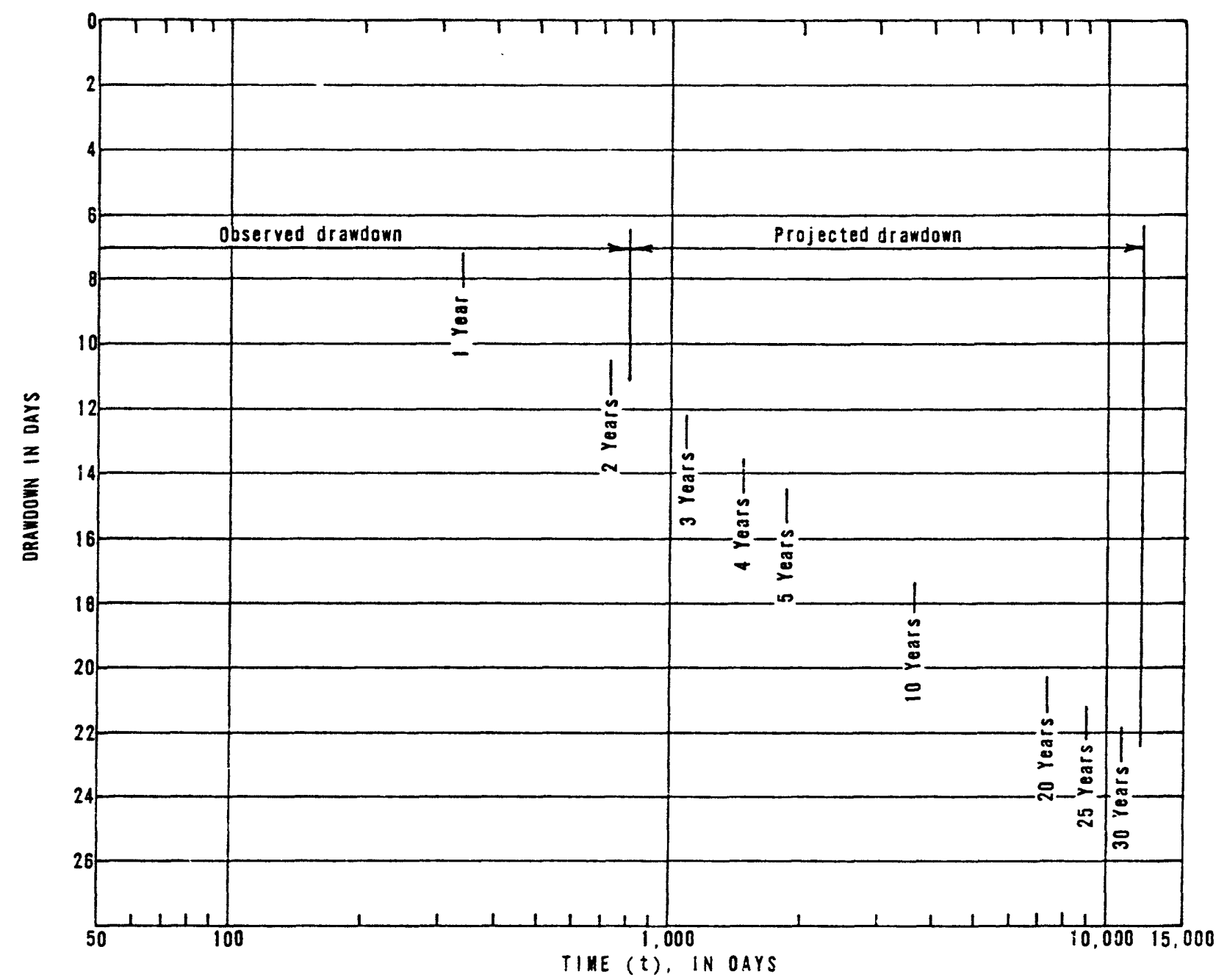

Figure 20.--Predicted time-drawdown for Collier Carbon and Chemical observation well 5B (well 10004).

The effect of pumpage from the North Kenai artesian system on the water-table aquifer is not known. In general, the decline of ground-water and lake levels is not markedly greater near the industrial wells than in the undeveloped areas. However, water levels in some observations wells in the water-table aquifer located near the industrial wells do show a sustained gradual decline, indicating possible effects of industrial pumpage. This is nat conclusive, however, and the principal cause of regional water-level declines from 1968 to 1970 is believed to be drought conditions during the period. 
Conclusive evidence of the extent that industrial pumpage affects water levels will require continued coliection of water-level data during several years of normal precipitation. A comparison can then be made between levels near the indus trial areas and those in other areas. From present information it is difficult to determine quantitatively how much water is pumped for industrial use from the water-table system. This would require a more detailed investigation.

Kenai.--The city of Kenai is situated on a coastal plain of outwash and shore deposits (pl. 1). The principal aquifer is unconfined and depth to the water table ranges from 2 to 20 feet; thickness of the aquifer ranges from 10 to 80 feet. A few wells produce from artesian aquifers at depths ranging from 180 to 250 feet below land surface. Yields of as much as $180 \mathrm{gpm}$ have been obtained from wells in the water-table aquifer, and as high as $50 \mathrm{gpm}$ from the artesian aquifer. However, both aquifers have had restricted development because of objectionable quantities of iron, dissolved minerals, or organic material.

Water produced in 1970 from the Kenai ground-water system is estimated to have been 200,000 gpd, almost all of which was developed from the water-table aquifer. About 100,000 gpd was used by Wildwood Air Force Base. The city of Kenai obtained its water from this aquifer from 1964 to 1970. During 1969, the city of Kenai's average use was 100,000 gpd (State of Alaskà, Department of Economic Development, 1970).

The hydraulic properties of the Kenai ground-water system are poorly known. Transmissivity of the water-table aquifer has an estimated range of 1,340 to $5,350 \mathrm{ft}^{2} \mathrm{day}^{-1}$ $(10,000$ to 40,000 gpd per foot) and hydraulic conductivity, a range of 13 to $54 \mathrm{ft} \mathrm{day}^{-1}$ ( 100 to $400 \mathrm{gpd}$ per square foot).

Mean annual recharge to the water-table aquifer underlying Kenai should be at least equal to the ground-water runoff in Beaver Creek valley. This rate would be 200,000 gpd per square mile, or 7 mgd over the entire area. 
The natural discharge from the system is estimated to include 2 to $4 \mathrm{mgd}$ from the springs along Cook Inlet, the remainder being discharged to streams or lost through evapotranspiration.

The maximum average sustained yield of the Kenai watertable aquifer is estimated to be from 2 to $7 \mathrm{mgd}$. It is greatly dependent upon the amount of storage that is available to accept water during periods of surplus and to retain water for use during periods of deficiency. An estimate of storage in the Kenai water-table aquifer is based on the following assumptions:

1. The average aquifer thickness is 65 feet.

2. The average depth to water is 5 feet; thus, there is about 60 feet of saturated section.

3. The average specific yield of the sediments is 20 percent.

On the basis of these assumptions, storage in the watertable aquifer is estimated to be 2,500 million gallons per square mile. However, it might be difficult to develop even one-third of this water.

There are no noticeable effects of ground-water development in the Kenai system. Expanded development may lower water levels in the water-table aquifer; however, this might be considered desirable because near-surface water levels are detrimental to building, road, and airfield foundations.

Beaver Creek Valley.--The abandoned-channel deposits of the Beaver Creek valley constitute a water-table aquifer ranging in depth from 15 to 80 feet. The water-table aquifer has only minor development.

The artesian aquifer underlying the Beaver Creek valley ranges in depth from 100 to more than 285 feet ard yields as much as 1,000 gpm to individual wells. Ground-water development in the artesian aquifer includes the rity of Kenai's use cf approximately $600,000 \mathrm{gpd}$ and less than 10,000 gpd from private welis. 
Transmissivity, determined from aquifer field tests ranges from 2,100 to $9,900 \mathrm{ft}^{2} \mathrm{day}^{-1}(16,000$ to $74,000 \mathrm{gpd}$ per foot); laboratory hydraulic conductivities of the aquifer material range from 1.7 to $76 \mathrm{ft} \mathrm{day-1}(13$ to 570 gpd per square foot). Like the North Kenai artesian aquifer, the Beaver Creek artesian aquifer has complex hydraulic characteristics and appears to be a leaky system. Figure 21 shows a drawdown curve and Hantush (1960) modified leaky-aquifer analysis for the city of Kenai production well 1 in Beaver Creek valley. For this test, as in the Collier Carbon and Chemical test, the data are not adequate for a unique solution of $B$, so a best fit for $B$ is given. The same data could be fit to a range of $\beta$ curves resulting in a corresponding range in aquifer characteristics.

Before leaky-artesian conditions were recognized in the Kenai-Soldotna area, aquifer test data from the Beaver Creek aquifer had been analyzed by the The is method (Anderson, 1971). The Theis method assumes that all water is withdrawn from storage in the aquifer and that there is no source of recharge to the aquifer. Reevaluation of the same data from Kenai production well 1 (fig. 21) resulted in a smaller transmissivity value than previously estimated (Anderson, 1971); however, the new interpretation does account for a probable source of recharge.

The boundaries of the Beaver Creek ground-water system (fig. 18) are assumed to correspond with the surficiai drainage divide of Beaver Creek, except in the southern part of the system where it coincides with the surficial expression of the abandoned-channel deposits (pl. 1).

Mean arnual recharge to the Beaver Creek water-table aquifer is estimated to be greater than the estimated groundwater runoff at the Beaver Creek gage, which averages $10 \mathrm{mgd}$. Recharge to the artesian aquifer would be by vertical leakage from the water-table aquifer and by ground-water underflow. 


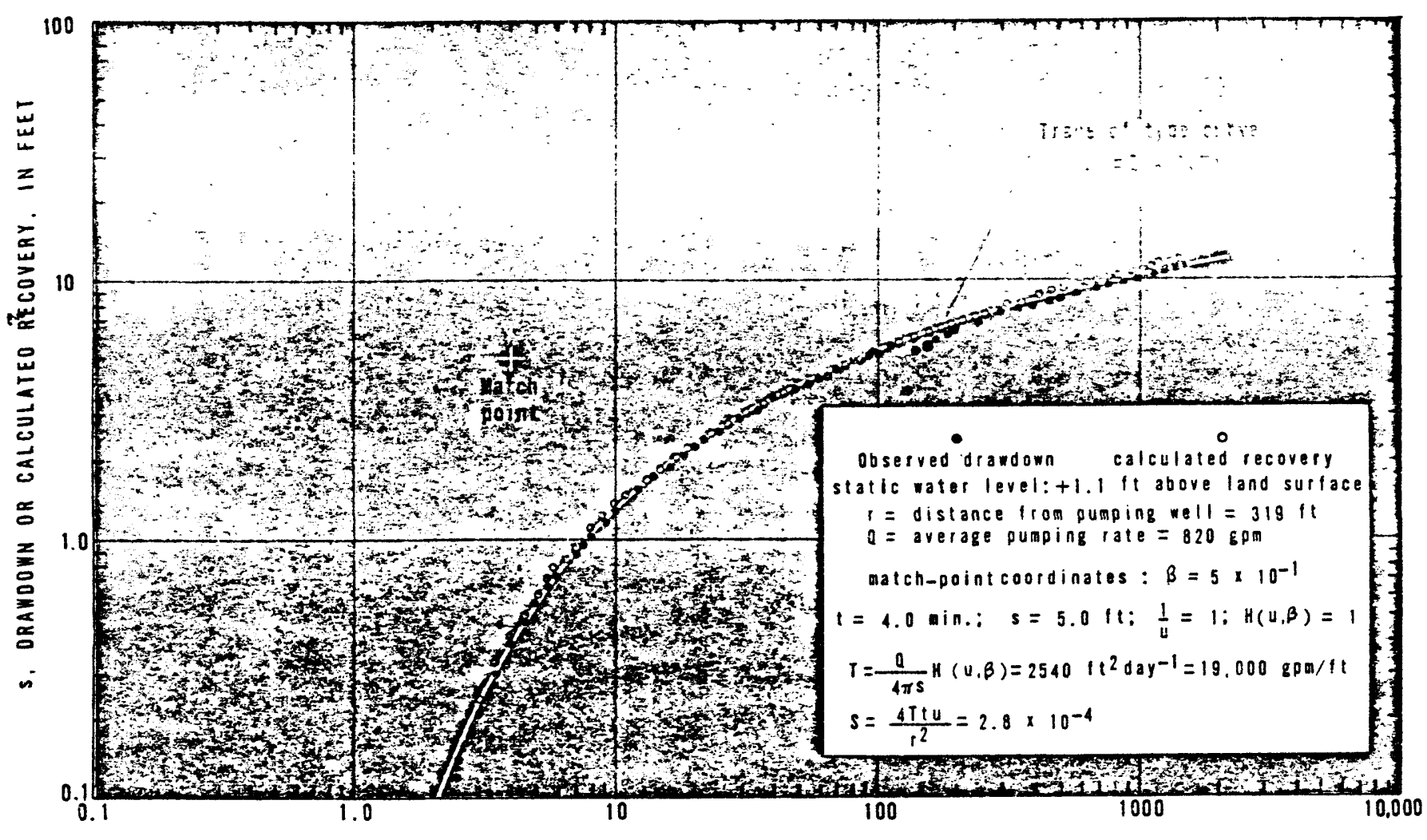

t. TIME SINCE PUMP STARTED OR STOPPED. IN MINUTES

Figure 21.--Aquifer test of Kenai production well (well 10871), August 11,1970 .

Ground-water discharge from the basin, as underflow in the artesian aquifer, cannot be calculated because the direction and gradient of flow are not known. However, flow in the artesian aquifer through profile B-B' (fig. 18) is estimated to be in the range of 0.5 to $1.0 \mathrm{mgd}$.

At present there are minimal effects from ground-water pumpage in the Beaver Creek valley artesian aquifer. Problems that can be anticipated from overdevelopment are:

* (1) Intrusion of salt water from Cook Inlet or from upward vertical leakage in the aquifer, (2) mutual interference between wells, (3) lowering of water levels in the watertable aquifers, or (4) depletion of ground-water runoff to Beaver creek. Of the potential problems, the intrusion of salt water is considered to be the most serious. If production wells are constructed north of the profile $B-B^{\prime}$ ( $f i g$. 18), the intrusion of undesirable water should be minimized, but monitoring of water-quality change in the southern part of 
the system is needed to detect detrimental changes that may occur. Mutual interference between wells can be minimized through the proper testing and continual monitoring of all production wells so that optimum spacing and pumping schedules can be established. Lowering of water levels in the watertable aquifer is not considered a serious problem because there are few shallow wells. Depletion of ground-water runoff in Beaver Creek could affect the fisheries, hut the anticipated ground-water withdrawal is small and should not markedly affect this runoff. A continuing stream-gaging program on Beaver Creek will help to identify any reduction in groundwater runoff.

Soldotna.--Alluvial and deltaic deposits of the Kenai River valley underlying Soldotna constitute a discontinuous water-tabie aquifer. Depth to the water table ranges from 15 to 50 feet and aquifer thickness ranges from a few to 80 feet.

Depth to the artesian aquifer, consisting of sand and gravelly sand, ranges from 75 to 220 feet below land surface. The greatest thickness of water-bearing material penetrated in a single hole is 60 feet.

We 17 yields from the artesian aquifer range from 10 to $516 \mathrm{gpm}$. The yield of $516 \mathrm{gpm}$ was an artesian flow from a 6 -inch open-end casing measured several weeks after the well had been drilled. Transmissivity is estimated to range from 1,300 to $5,300 \mathrm{ft}^{2}$ day-1 $(10,000$ to $40,000 \mathrm{gpd}$ per $\mathrm{ft})$. A test in the Soldotna production well (fig. 22) was anaiyzed using the Hantush (1960) modified leaky-aquifer analysis. Difficulties with these data, similar to those discussed in the North Kenai and Beaver Creek valley tests, result in a range of $B$ and associated transmissivity and storage coefficent values. 


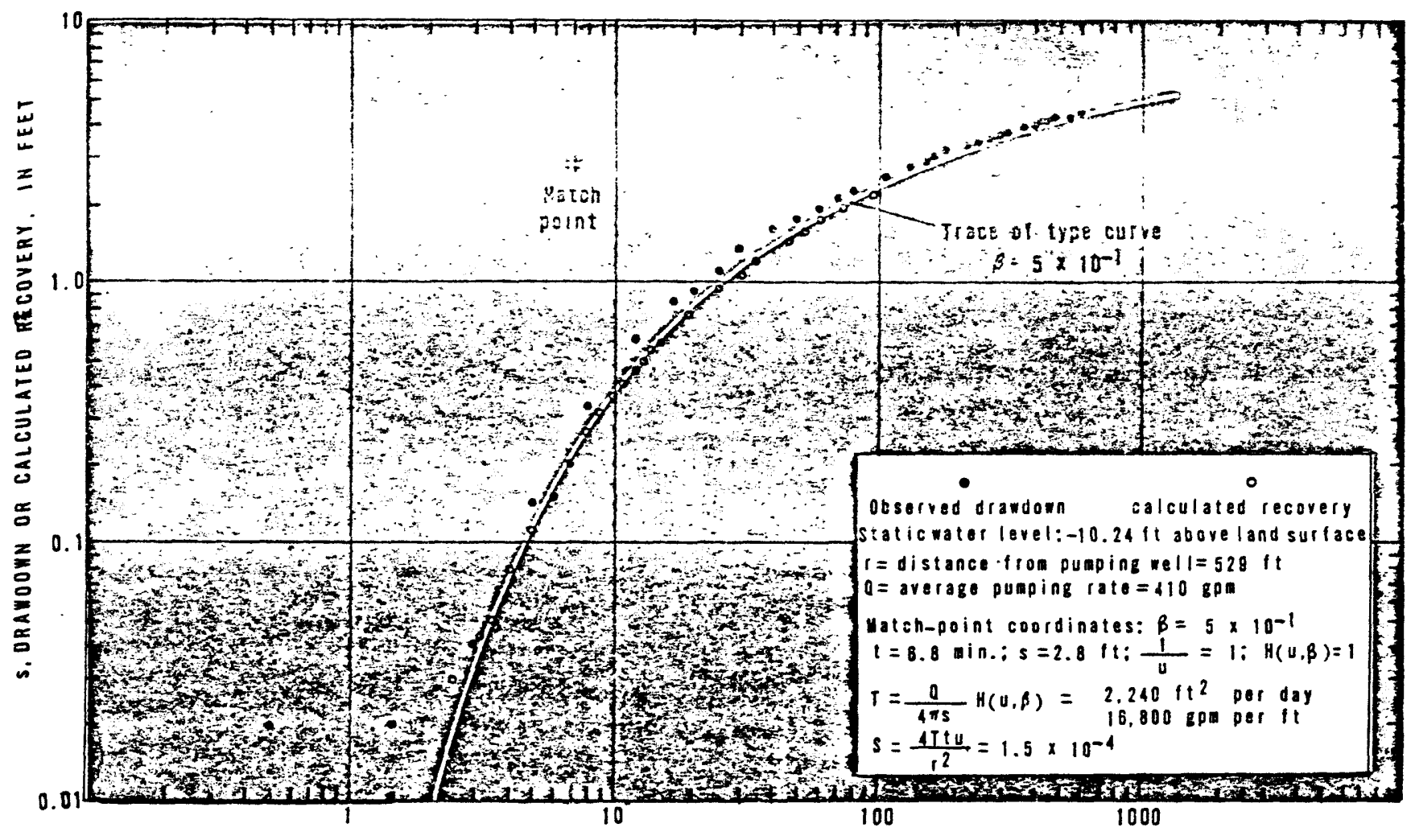

t. TIME SINCE PUMP STARTED OR STOPPED, IN MINUTES

Figure 22.--Aquifer test of Soldotna production well (wel1 10161), July 23,1971 .

Water development from the Soldotna ground-water system is principally by private wells in the artesian aquifer. Total water consumption during 1970 was estimated to be 120,000 gpd.

Geohydrologic boundaries of the Soldotna ground-water system are uncertain but appear to coincide with the areal extent of the alluvial and deltaic sediments (pl. 1). Accordingly, no quantitative estimate of the recharge to or discharge from this system can be made.

Ground-water pumpage is causing a local decline of the potentiometric surface at Soldotna. This deciine is most pronounced in the vicinity of tree Soldotna municipal well. However, such a decline is normal and no adverse effects are anticipated provided future high-capacity wells are spaced to minimize mutual interference. 


\section{QUALITY OF WATER}

The quality of water in the Kenai-Soldotna area varies widely; in most places the water is of suitable chemical quality for domestic and many industrial uses. A few artesian wells yield water that is unsuitable for use because of high mineralization and color, and in many areas the water-table wells yield water that has excessive amounts of iron. The Kenai and Kasilof Rivers are low in dissolved minerals but heavily laden with glacial flour. A few wells close to cook Inlet and the tide-affected reaches of the rivers are contaminated with salt water.

\section{Chemical Constituents in Relation to Use}

The chemical character of water governs its suitability for most uses. Domestic users are chiefly concerned with the hardness, iron content, pH, color, turbidity, odor, and the content of dissolved solids, chloride, and fluoride, and the bacteriological quality of the water. Industrial users are concerned with most of these and also with' silica content and temperature of the water.

Selected chemical analyses are included in tables 3 and 4. The source, significance, and concentrations of dissolved minerà constituents and physical properties of Kenai-soldotna area water are summarized in table 5 .

The general discussion of these constituents has been adapted from publications of the U.S. Geological Survey. Also included in the discussion, where appropriate, is information concerning industrial experience with the water in the Kenai area (A. D. Houtz, Collier Carbon and Chemical Corp., written commun., 1971). 
Table 3.--Selected chemical analyses of ground water, Kenai-Soldotna area.

\begin{tabular}{|c|c|c|c|c|c|c|c|c|c|c|c|c|c|c|c|c|c|c|c|c|}
\hline & & & & & & & & & & & & & & & & & & $\begin{array}{l}\text { speciste } \\
\text { conduct- }\end{array}$ & & \\
\hline enter & 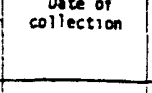 & Aquifer & $\begin{array}{l}\text { Sempling } \\
\text { oeperts } \\
(\mathrm{it})\end{array}$ & 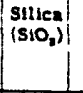 & $\begin{array}{l}\text { Iron } \\
(x \in)\end{array}$ & $\begin{array}{l}\text { Cal. } \\
\text { elum } \\
\text { (ca) }\end{array}$ & $\begin{array}{l}\text { se: } \\
\text { sium } \\
\text { (Mg) }\end{array}$ & 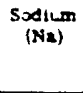 & 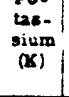 & 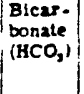 & $\begin{array}{l}\text { Sulface } \\
(\mathbf{S O},)^{2}\end{array}$ & $\begin{array}{l}\text { Chloride } \\
\text { (CI) }\end{array}$ & te & (N) & $\begin{array}{l}\text { solids } \\
\text { (residue } \\
\text { at } 180^{\circ} \mathrm{C} \text { ) }\end{array}$ & $\begin{array}{l}\text { Calcum } \\
\text { maznene } \\
\text { siumen }\end{array}$ & $\begin{array}{c}\text { Non- } \\
\text { :rbbon- } \\
\text { ate }\end{array}$ & 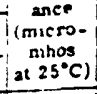 & ${ }^{\mathrm{pH}}$ & Colo \\
\hline & & & & & & & & & & WORTH KE & & & & & & & & & & \\
\hline 16 & 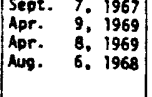 & 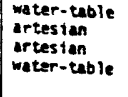 & $\begin{array}{l}150 \\
157 \\
77\end{array}$ & $\begin{array}{l}29 \\
29 \\
30 \\
24\end{array}$ & $\begin{array}{r}0.06 \\
.183 \\
1.23 \\
1.20\end{array}$ & $\begin{array}{l}19 \\
11 \\
17 \\
17\end{array}$ & $\begin{array}{l}1.5 \\
6.5 \\
3.4 \\
2.9\end{array}$ & $\begin{array}{l}5.8 \\
4.8 \\
4.4\end{array}$ & $\begin{array}{l}1.8 \\
6.5 \\
3.5 \\
2.8\end{array}$ & $\mid \begin{array}{l}71 \\
83 \\
64 \\
72\end{array}$ & $\begin{array}{l}0.0 \\
3.5 \\
13.5 \\
.0\end{array}$ & $\begin{array}{l}7.4 \\
2.8 \\
2.8 \\
3.6\end{array}$ & $\begin{array}{r}0.8 \\
.1 \\
.2\end{array}$ & $\begin{array}{r}1.9 \\
1.0 \\
.8\end{array}$ & $\begin{array}{l}104 \\
106 \\
107 \\
91\end{array}$ & 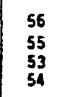 & $\begin{array}{l}0 \\
: \\
0\end{array}$ & $\begin{array}{l}139 \\
140 \\
128 \\
128\end{array}$ & $\begin{array}{l}7.3 \\
8.0 \\
8.0 \\
7.4\end{array}$ & $\begin{array}{l}10 \\
10 \\
10 \\
25\end{array}$ \\
\hline (150 & 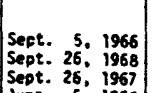 & \begin{tabular}{|l} 
artestian \\
arater-tablo \\
artersitan
\end{tabular} & $\begin{array}{l}268 \\
65 \\
207\end{array}$ & $\begin{array}{l}26 \\
45\end{array}$ & 0.42 & $\frac{19}{20}$ & 11.8 & 3.96 & 13.2 & \begin{tabular}{|c|} 
KEMAT \\
505 \\
88 \\
38
\end{tabular} & 36 & 4.4 & 1.7 & 2.3 & 点 1270 & $\begin{array}{l}92 \\
68\end{array}$ & $:$ & $\begin{array}{l}2160 \\
196 \\
0.5\end{array}$ & $\begin{array}{l}8.5 \\
6.8 \\
8.0\end{array}$ & 10 \\
\hline & Jume S, 1968 & water-t & 53 & $\mathbf{2 2}$ & 1.31 & $28^{-2}$ & 2.2 & ${ }_{4.5}^{108}$ & & $\mid \begin{array}{l}308 \\
0.68 \\
\text { QR CREEK }\end{array}$ & $\begin{array}{l}2.0 \\
.6 \\
\text { VALLEY }\end{array}$ & $5_{4.6}^{5.6}$ & .0 & 2.2 & $\begin{array}{l}307 \\
116\end{array}$ & $\dot{9}$ & 0 & 182 & & \\
\hline & 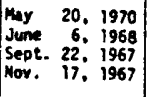 & 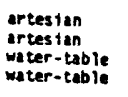 & $\begin{array}{r}243 \\
135 \\
40 \\
85\end{array}$ & $\begin{array}{l}\begin{array}{c}4 \\
12 \\
25 \\
36\end{array} \\
36\end{array}$ & $\begin{array}{l}0.38 \\
4.64 \\
4.19 \\
.35\end{array}$ & $\begin{array}{l}0.3 \\
9.5 \\
9.5 \\
19\end{array}$ & $\begin{array}{l}0.3 \\
6.1 \\
i .6 \\
3.3\end{array}$ & $\begin{array}{c}52 \\
340 \\
6.9 \\
3.0\end{array}$ & $\begin{array}{l}2.6 \\
8.0 \\
2.0 \\
2.0\end{array}$ & $\left|\begin{array}{c|}136 \\
178 \\
76 \\
49 \\
89\end{array}\right|$ & $\begin{array}{l}0.0 \\
.4 \\
: 0 \\
: 0\end{array}$ & $\begin{array}{r}0.7 \\
4.6 \\
3.6 \\
3.2\end{array}$ & $\begin{aligned} 0.5 \\
: 1 \\
: 1\end{aligned}$ & $\begin{array}{l}0.6 \\
4.0 \\
4.5\end{array}$ & $\begin{array}{l}168 \\
936 \\
79 \\
86\end{array}$ & $\begin{array}{l}31 \\
36 \\
30 \\
66\end{array}$ & $\begin{array}{l}0 \\
0 \\
0 \\
0\end{array}$ & $\begin{aligned} 217 \\
1700 \\
84 \\
197\end{aligned}$ & $\begin{array}{l}8.2 \\
8.2 \\
6.9 \\
7.7\end{array}$ & $\begin{array}{c}20 \\
500 \\
5\end{array}$ \\
\hline & $\begin{array}{l}\text { June } \\
\text { Seat. } \\
27\end{array}, 1968$ & & 163 & $4^{43}$ & 0.29 & 22 & 13. & 70 & 4.9 & 163 & 8.1 & 92 & 0.2 & 2.6 & 336 & 108 & 0 & 558 & 7.9 & \\
\hline & 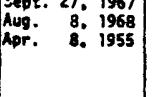 & & $\begin{array}{l}75 \\
35 \\
54\end{array}$ & $\begin{array}{l}42 \\
20 \\
39\end{array}$ & $\begin{array}{l}.46 \\
.100 \\
.03\end{array}$ & $\begin{array}{l}43 \\
14 \\
34\end{array}$ & $\begin{array}{l}5.2 \\
7.0 \\
7.6\end{array}$ & $\begin{array}{r}37 \\
4.6 \\
6.2\end{array}$ & $\begin{array}{l}4.2 \\
3.3 \\
3.2 \\
\end{array}$ & $\mid$ & $\begin{array}{r}.0 \\
16\end{array}$ & $\begin{array}{l}36 \\
2.6 \\
2.0\end{array}$ & $\begin{array}{l}.2 \\
.0 \\
.2\end{array}$ & $\begin{array}{r}.6 \\
.6 \\
.2\end{array}$ & & $\begin{array}{l}128 \\
52 \\
116\end{array}$ & $\begin{array}{l}0 \\
0 \\
0 \\
2\end{array}$ & $\begin{array}{l}402 \\
125 \\
247\end{array}$ & $\begin{array}{l}8.0 \\
7.2 \\
8.0\end{array}$ & \\
\hline & Apr. 2, 1968 & artesten & 197 & 24 & 0.35 & 21 & 6.0 & 48 & 2.0 & 222 & 0.0 & 0.7 & 0.1 & 0.5 & 211 & $n$ & 0 & 330 & 7.8 & 10 \\
\hline & & & & & 0.30 & & & & & & & & & & & & & & & \\
\hline
\end{tabular}

Table 4.--Selected chemical analyses of surface water, Kenai-Soldotna area.

\begin{tabular}{|c|c|c|c|c|c|c|c|c|c|c|c|c|c|c|c|c|c|c|}
\hline \multirow[b]{2}{*}{$\begin{array}{l}\text { Date of collection } \\
\text { - }\end{array}$} & \multirow{2}{*}{$\underset{\text { discharge }}{\text { (efs) }}$} & \multirow[b]{2}{*}{$\begin{array}{l}\text { Silica } \\
\text { (S10, }\end{array}$} & \multirow[b]{2}{*}{$\begin{array}{l}\text { Iron } \\
\text { (Fo) }\end{array}$} & \multirow{2}{*}{$\begin{array}{l}\text { Cal- } \\
\text { ctum } \\
\text { (Ca) }\end{array}$} & \multirow{2}{*}{$\begin{array}{l}\text { Mag- } \\
\text { ne- } \\
\text { stum } \\
\text { (Mq) }\end{array}$} & \multirow[b]{2}{*}{$\begin{array}{c}\text { Sodium } \\
\text { (Na) }\end{array}$} & \multirow{2}{*}{$\begin{array}{l}\text { Po- } \\
\text { tas- } \\
\text { stum } \\
\text { (K) }\end{array}$} & \multirow{2}{*}{$\begin{array}{l}\text { Bicar- } \\
\text { bonate } \\
\text { (HCO,) }\end{array}$} & \multirow[b]{2}{*}{$\begin{array}{l}\text { Sullate } \\
\text { (90,) }\end{array}$} & \multirow[b]{2}{*}{$\begin{array}{l}\text { Chloride } \\
\text { (CI) }\end{array}$} & \multirow{2}{*}{$\begin{array}{l}\text { Fluo- } \\
\text { ride } \\
\text { (F) }\end{array}$} & \multirow{2}{*}{$\begin{array}{c}\text { Ni- } \\
\text { trate } \\
\text { (NO, })\end{array}$} & \multirow{2}{*}{$\begin{array}{c}\text { Dissolved } \\
\text { solids } \\
\text { (residue } \\
\text { at } 180^{\circ} \mathrm{C} \text { ) }\end{array}$} & \multicolumn{2}{|c|}{$\begin{array}{l}\text { Hardness } \\
\text { 2s } \mathrm{Ca}_{2} \mathrm{CO} \text {, }\end{array}$} & \multirow{2}{*}{$\begin{array}{l}\text { Speetific } \\
\text { conduct- } \\
\text { 2nce } \\
\text { (micro- } \\
\text { mhos } \\
\text { at } 25^{\circ} \mathrm{C} \text { ) }\end{array}$} & \multirow[b]{2}{*}{ pH } & \multirow[b]{2}{*}{ Color } \\
\hline & & & & & & & & & & & & & & $\begin{array}{l}\text { Calchim } \\
\text { magne- } \\
\text { sium }\end{array}$ & $\begin{array}{l}\text { Non- } \\
\text { carbon- } \\
\text { ate }\end{array}$ & & & \\
\hline & & & & & & $15-2$ & 20 KASI & LOF RIVE & MEAR KAS & & & & & & & & & \\
\hline Dec. 12. 1957 & 2020 & 5.0 & 0.17 & 4.8 & 1.2 & $\begin{array}{c}1.6 \\
15-2661\end{array}$ & $\begin{array}{c}1.7 \\
\text { ENAI RI }\end{array}$ & $\begin{array}{c}20 \\
\text { VER AT SK }\end{array}$ & $\begin{array}{c}3.0 \\
\text { LLAK LAKE }\end{array}$ & $\begin{array}{l}1.0 \\
\text { UTLET }\end{array}$ & 0.0 & 0.3 & 28 & 17 & 0 & 43 & 6.6 & 20 \\
\hline Nov. 2, 1967 & 3230 & 3.1 & 0.60 & 10 & 0.8 & $\begin{array}{l}0.7 \\
15-2661\end{array}$ & $\begin{array}{r}1.0 \\
.2 \mathrm{kILL}\end{array}$ & $\begin{array}{ll}27 & 27 \\
\text { EY RIVER }\end{array}$ & $\begin{array}{l}6.0 \\
\text { IEAR STERI }\end{array}$ & 0.4 & 0.0 & 0.7 & 36 & 29 & 7 & 64 & 7.2 & 5 \\
\hline Nov. 2. 1967 & 233 & 9.8 & 0.20 & 8.2 & 1.0 & $\begin{array}{l}3.1 \\
15-266\end{array}$ & $\begin{array}{c}0.7 \\
1.6 \mathrm{KEN}\end{array}$ & $\begin{array}{ll}26 & 26 \\
\text { AI } & \text { RIVER }\end{array}$ & $\begin{array}{l}7.0 \\
\text { LEAR STERL }\end{array}$ & NG & 0.0 & 1.2 & 46 & 25 & 4 & 71 & 7.1 & 0 \\
\hline Hov. 2, 1967 & 3150 & 3.6 & 0.53 & 10 & 0.8 & $\begin{array}{l}0.8 \\
15-266\end{array}$ & $\begin{array}{l}0.9 \\
1.8 \mathrm{H}\end{array}$ & SE RIVER & $\begin{array}{l}8.0 \\
\text { EEAR STERL }\end{array}$ & 0.4 & 0.0 & 0.6 & 39 & 29 & 6 & 64 & 7.3 & 5 \\
\hline Nov. ', 1967 & 126 & 15 & 0.69 & 23 & 4.2 & $\begin{array}{l}4.2 \\
15-266\end{array}$ & $\begin{array}{l}1.3 \\
.1 \text { FUN }\end{array}$ & $\mid$ & $\begin{array}{l}0.0 \\
\text { EEAR SOLD }\end{array}$ & NA & 0.1 & 2.6 & 99 & 76 & 0 & 159 & 7.8 & 10 \\
\hline Hor. ?, 1967 & 107 & 18 & 0.91 & 10 & 3.6 & $\begin{array}{l}3.0 \\
15-2662\end{array}$ & $\begin{array}{c}0.9 \\
9 \mathrm{SOLD}\end{array}$ & \begin{tabular}{|c|}
54 \\
OTNA CREE
\end{tabular} & $\begin{array}{l}0.0 \\
\text { AT SOLDO }\end{array}$ & 0.4 & 0.0 & 0.6 & 64 & 41 & 0 & 93 & 7.3 & 15 \\
\hline Apr. 2. 1963 & 15.6 & 29、 & 0.83 & 15 & 5.3 & $\begin{array}{l}5.5 \\
15-2\end{array}$ & $2.3 \mid$ & \begin{tabular}{|c|} 
\\
AI RIVER
\end{tabular} & $\begin{array}{c}0.0 \\
\text { T SOLDOTN }\end{array}$ & 1.4 & 0.1 & 0.4 & 111 & 70 & 0 & 158 & 7.4 & 15 \\
\hline Nov. 7, 1970 & $\mathbf{5 9 8 0}$ & 3.5 & ${ }^{*} 0.03$ & 9.8 & 1.0 & $\begin{array}{l}1.6 \\
15-2\end{array}$ & $\begin{array}{l}1.0 \\
65 \mathrm{BEAl}\end{array}$ & 29 & $\begin{array}{c}6.3 \\
\text { NEAR KENA }\end{array}$ & 0.0 & 0.1 & 1.2 & 39 & 29 & 5 & 69 & 7.0 & 0 \\
\hline Oct. 1, 1970 & 19.9 & $2 B$ & $* 1.20$ & 18 & 3.9 & $\begin{array}{l}5.1 \\
15-26\end{array}$ & \begin{tabular}{|l|}
2.1 \\
9 8ERN]
\end{tabular} & \begin{tabular}{|c|}
79 \\
$C E$
\end{tabular} & $\begin{array}{l}3.0 \\
\text { NEAR KEMA }\end{array}$ & 3.5 & 0.2 & 0.1 & 106 & $6 !$ & 0 & 137 & 8.0 & 20 \\
\hline Apr. 3, 1968 & 1.33 & 20 & 0.51 & 1.8 & 2.4 & 3.9 & 670 uts & $\begin{array}{c}38 \\
\text { HOP CREE }\end{array}$ & $\begin{array}{l}1.0 \\
\text { NEAP XEN }\end{array}$ & 5.3 & 0.1 & 0.3 & 62 & 30 & 0 & 85 & 7.0 & 5 \\
\hline Se>t. 30,1970 & 15.1 & 14 & 0.70 & 12 & 2.9 & $\begin{array}{l}4.2 \\
15-267\end{array}$ & $\begin{array}{c}1.6 \\
.5 \mathrm{sin} \alpha \mathrm{N}\end{array}$ & 51 & $\begin{array}{l}3.0 \\
\text { NEAR STE }\end{array}$ & $\begin{array}{l}3.2 \\
\text { LING }\end{array}$ & 0.2 & 0.3 & 66 & 42 & 0 & 100 & 7.4 & 10 \\
\hline Dec. 2, 1953 & --- & 15 & 1.10 & 21 & 5.5 & 6.5 & $\begin{array}{r}1.9 \\
671.65\end{array}$ & 103 & $\begin{array}{l}1.0 \\
\text { VER NEAR }\end{array}$ & $\begin{array}{l}3.5 \\
\text { AAI }\end{array}$ & 0.1 & 0.3 & 107 & 75 & 0 & 171 & 7.0 & 45 \\
\hline Aur. 20.1969 & -.. & 16 & 0.48 & 29 & 6.4 & & $2.5 \mid$ & 140 & 0.4 & 3.5 & 0.1 & 0.01 & 129 & 99 & 0 & 225 & 8.3 & - \\
\hline
\end{tabular}




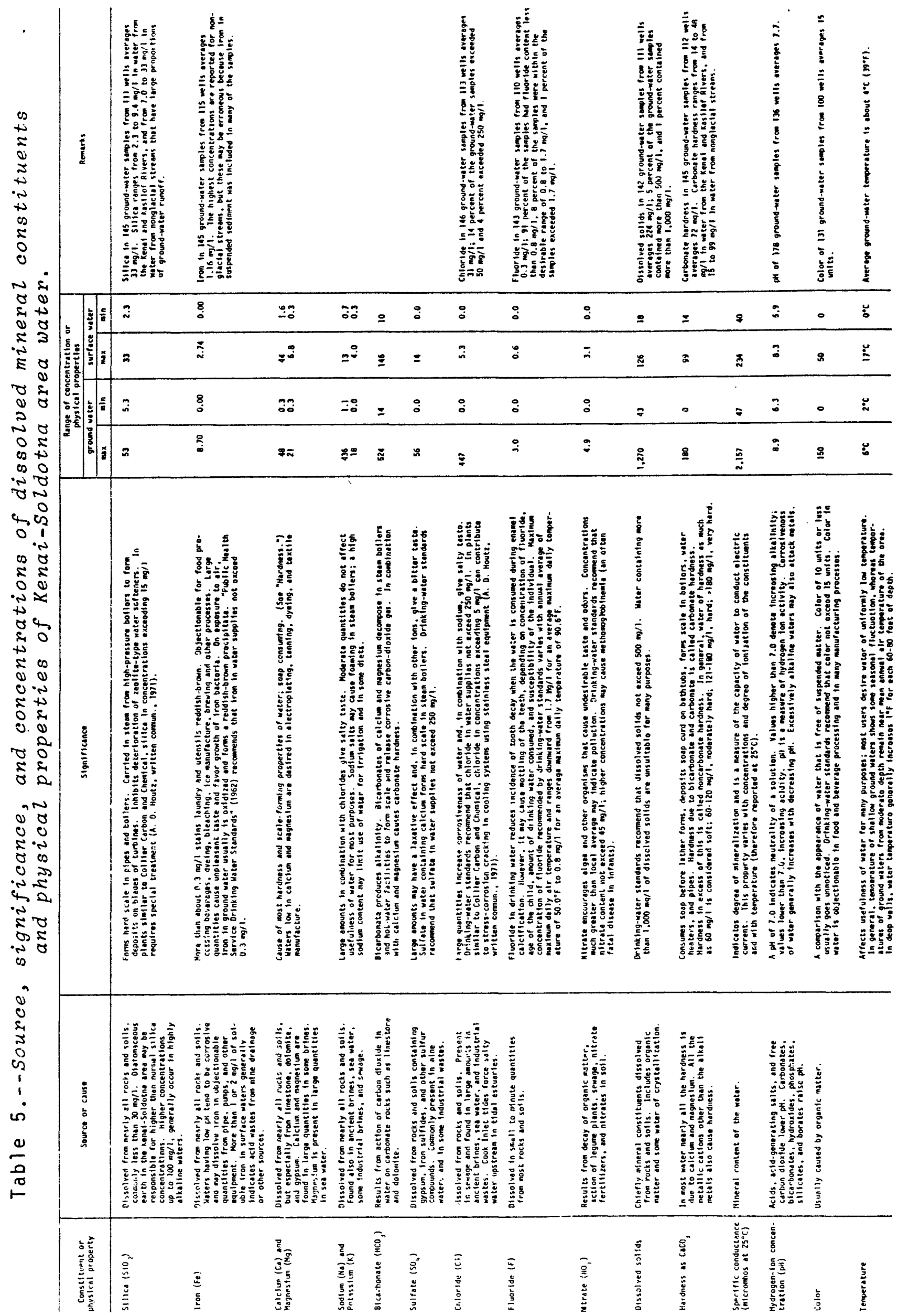


Ground-Water Quality

Ground-water quality varies considerably from well to well in the study area. The greatest concentration difference within the local areas is between wells in the water-table aquifers and those tapping artesian aquifers. An area of generally unsatisfactory ground-water quality is located in the lower Kenai River valley and along the Cook Inlet shoreline (fig. 23). In this area water from the water-table aquifer commonly has objectionable concentrations of iron, and water from the artesian aquifer has objectionable quantities of dissolved solids, chloride, or color.

\section{Water-Table Aquifers}

In the Kenai-Soldotna area, water of water-table aquifers is a calcium magnesium bicarbonate type. Chemical properties of this type of water are dominated by carbonate, bicarbonate, calcium, and magnesium, which produce carbonate or temporary. haraness. The water characteristically has a low dissolvedsolids content but commonly has a high iron content (table 6). The highest and most objectionable iron content occurs in water samples collected from the poorly drained swampy areas near Kenai, the area delineated as ground water of inferior quality (fig. 23). The spatial distribution of iron content in the water-table aquifer is illustrated in figure 24 .

\section{Artesian Aquifers}

The artesian aquifer can be separated into an area of generally satisfactory quality and an area of generally unsatisfactory quality as delineated in figure 23. The area of unsatisfactory water quality encompasses those sections in which a predominance of samples have one or more chemical constituents which exceed the recommended U.S. Public Heaith Service (i962) water-quality standards. Also, within this area, many well users report that the water has objectionable water-quaity characteristics. 


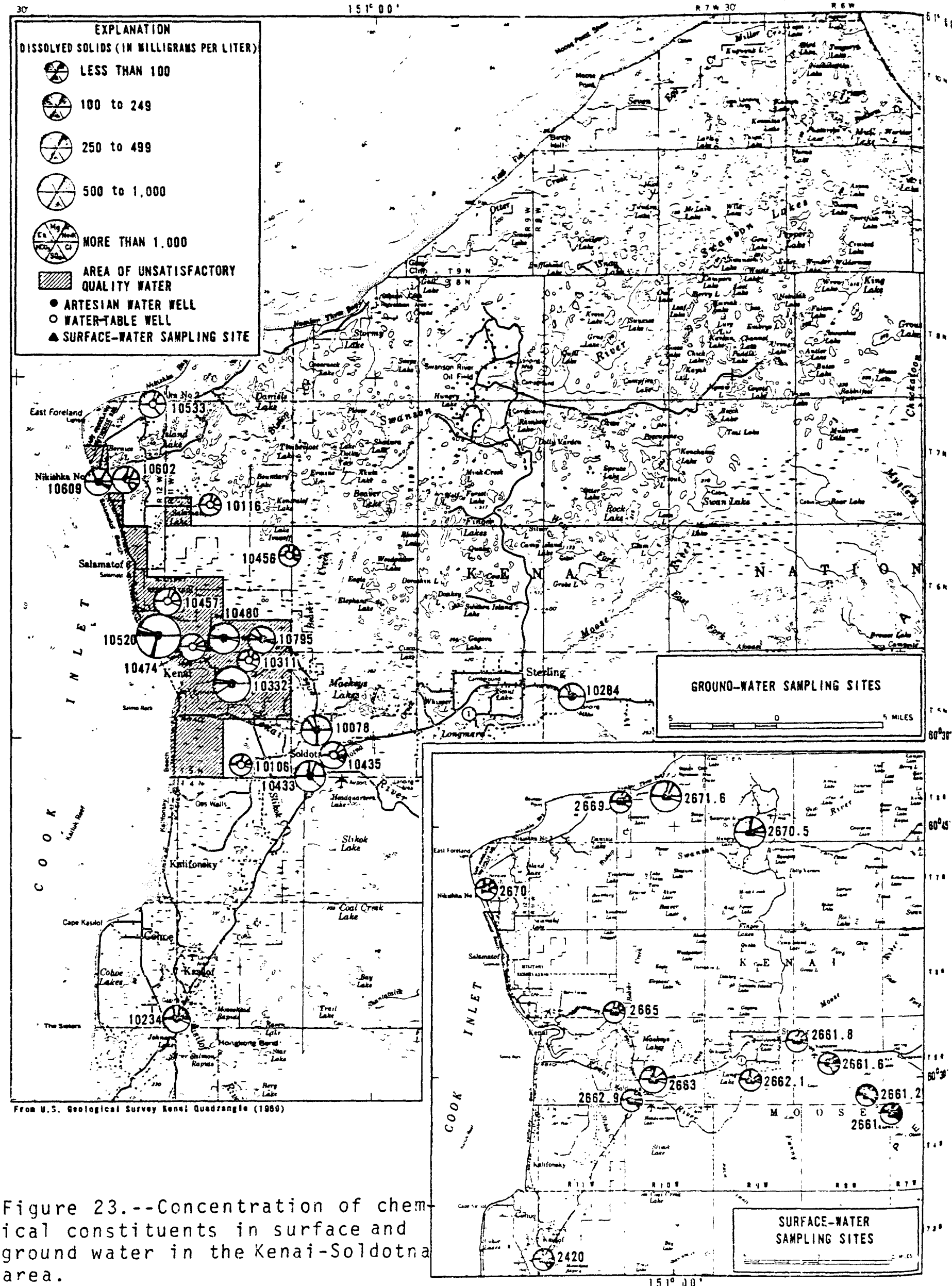




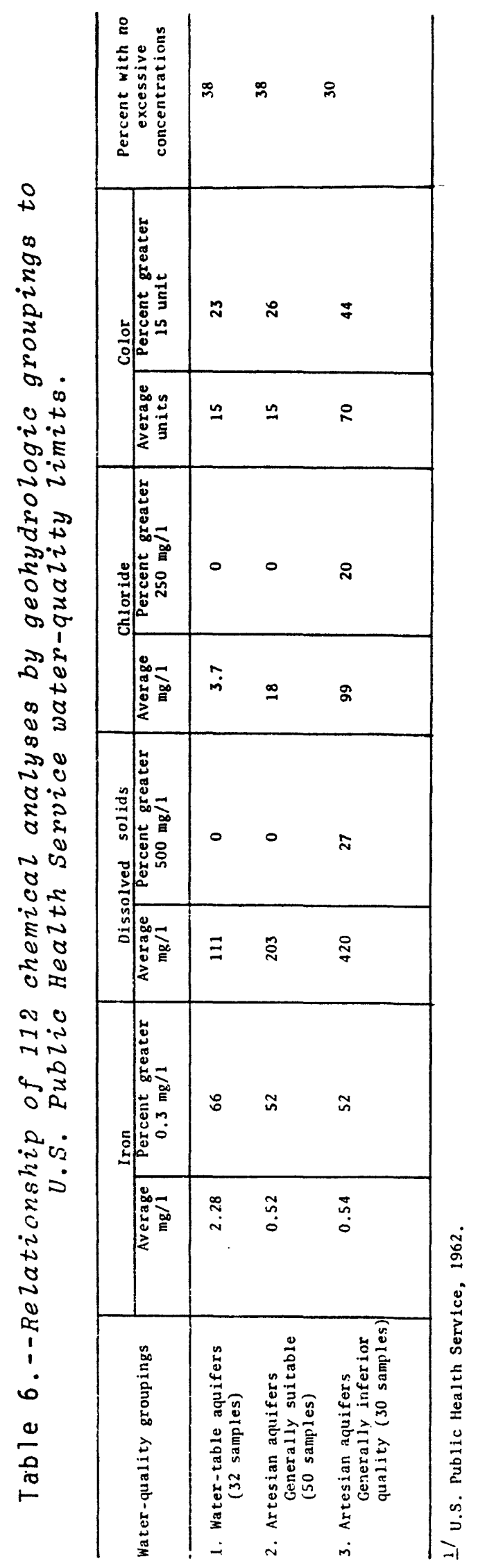




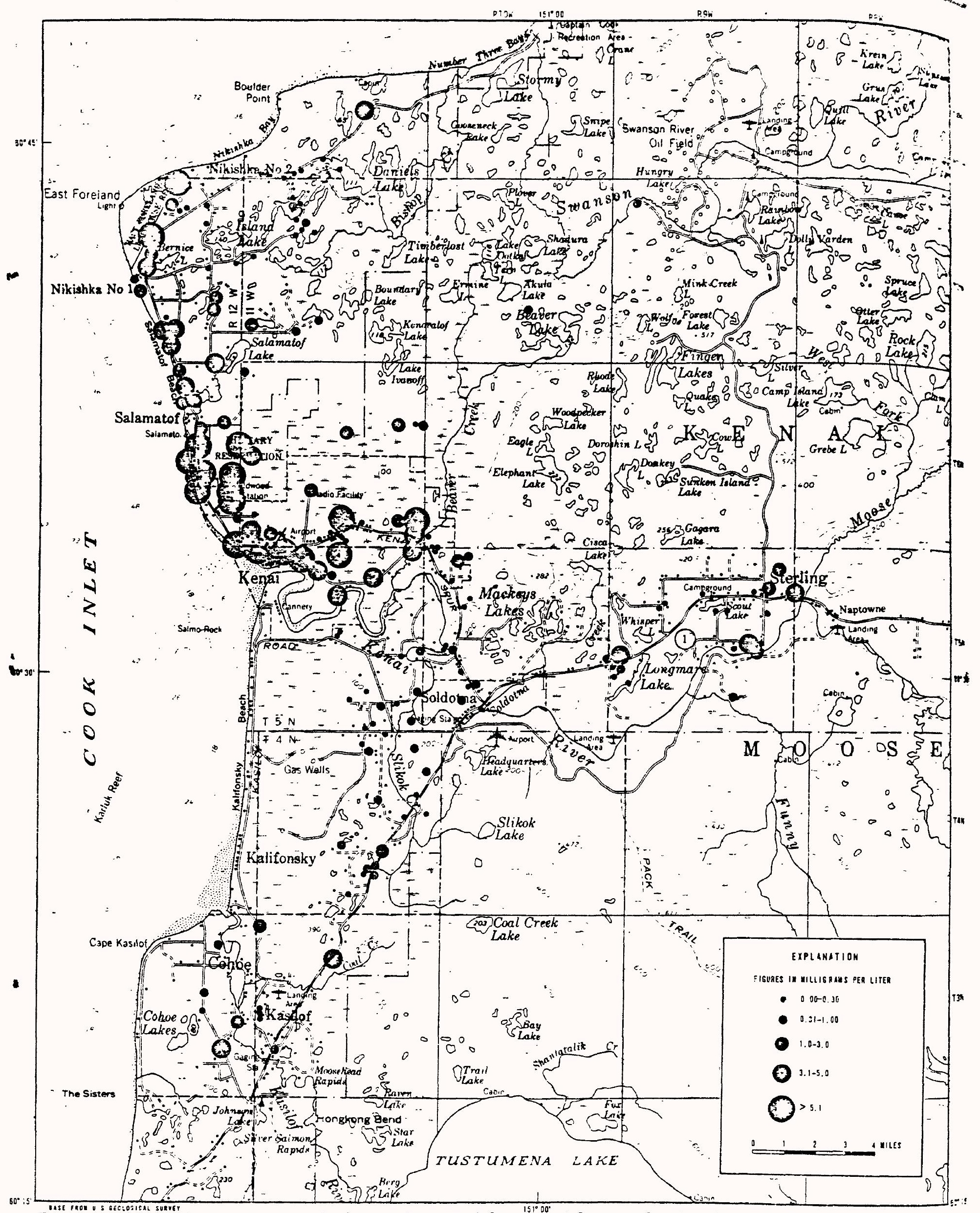

Figure $24 .-$ - Iron content in water-table ${ }_{a}^{15} q_{i} u i f e r s$ of the Kenai-Soldotna area, Alaska. 
Generally Satisfactory Ground Water

The water from artesian aquifers, which range fro- 60 to 300 feet below land surface, is commoniy of the best quality in the study area. It is principally of the calcium magnesium bicarbonate type but includes water of the sodium bicarbonate type, water with no dominant cation-anion pair type, and water of the sodium chloride type. Waters having a dominant sodium cation or a dominant chioride anion are found in the deeper artesian aquifers of the Kenai River valiey or near Cook Inlet.

Although over half of the ground-water samples collected contained iron concentrations greater than $0.3 \mathrm{mg} / 1$ (table 6 ), the concentration of iron is generally at a level that can be tolerated without treatment or that can be treated without difficulty. As the iron-rich water-table ground water infiltrates to the artesian aquifers, the water reacts more quickly with limy material than with iron-bearing materials and the water becomes harder with decreasing solubility of iron.

Artesian ground water near the recharge area is moderately hard, and the iron content, although objectionably high for ordinary uses, remains relatively low with reference to the total amount of dissolved solids. As the artesian waters move downgradient, they become extraordinarily soft, although the dissolved-solids content increases.

\section{Generally Unsatisfactory Ground Water}

Artesian water of unsatisfactory quality occurs in wells at depths ranging from 100 to 450 feet below land surface near the natural discharge areas (fig. 11). Most of the samples are of the sodium bicarbonate or sodium chloride types.

A large percentage of samples has dissolved-solids contents of more than $250 \mathrm{mg} / 1$ or color of more than 75 units. However, some samples from this area are of good quality, 
especially those from the Beaver Creek valley. Iron contents are similar to those in other artesian water (table 6).

\section{Saline Ground Water}

Ground water from some wells near Cook Inlet has been reported to be unsatisfactory because it is salty. This has been confirmed by chemical analyses, which show either high dissolved solids or high chloride, but neither the source nor the distribution of this water type is known.

Ground water from two wells near cook inlet had dissolvedsolids content of more than $1,000 \mathrm{mg} / 1$ and is probably brackish. Ground water from six wells had chloride contents of more than $250 \mathrm{mg} / 1$, the approximate concentration at which water will taste salty to some people. Nine sampled wells yield water having a dominance of chloride anions and sodium cations.

Saline water may accumulate by any of the following processes: (1) Retention of salt water trapped at the time of deposition, or (2) intrusion of salt water after deposition due to a rise in sea level or a decrease in discharge, or (3) dissolution of minerais and concentration of the constituents by filtration by clays. The most probable cause of saline ground water in the Kenai-Soldotna area is entrapment of salt water at the time of sediment deposition. However, heavy ground-water development could cause a change in the present ground-water flow patterns resulting in intrusion of sea water or movement of the older entrapped water towards the areas of development.

\section{Surface-Water Quality}

Surface water in the Kenai-Soldotna area is generally of good quality. Water of glacial streams such as the Kenai and Kasi?of Rivers is low in dissolved solids, 
presumably because its source is mainly snow and ice melt, but the streams contain glacial flour. However, glacial stream-sediment loads, in the study area, are relatively low because of the large lakes in which the coarse sediment settles.

The nonglacial streams of the Kenai-Soldotna area, such as Moose River and Beaver Creek, differ in water quality from the glacial streams. The quality of water from these streams is similar to ground water from water-table aquifers because their principal source is ground-water runoff. However, iron content is lower in the water from nonglacial streams than in shallow ground water. The sediment loads of nonglacial streams are lower than those of glacial streams.

\section{Chemical Quality of Surface Water}

All surface waters in the Kenai-Soldotna area are of the calcium magnesium bicarbonate type and are low in dissolved solids and chloride content and hardness. The concentrations of silica, dissolved solids, and iron and the hardness and color, however, are generally less in glacial streams (Kenai and Kasilof Rivers) than in nonglacial streams (Moose River and Beaver Creek) (table 7 ).

Water from all the streams generally meets all U.S. Public Health Service (1962) water-quality standards except for iron content and color. However, many of the reported higher iron concentrations were analyzed in such a manner that they inciude iron dissolved from suspended sediments. - This iron could readily be removed by coagulation, sedimentation, or filtration as is done in many treatment piarits. Hence the reported high iron concentrations should not preclude consideration for use of water from these streams. 
Table 7.--Relationship of chemical analyses from five streams to U.S. Public Health Service water-quality limits.

\begin{tabular}{|c|c|c|c|c|c|c|c|c|c|c|c|}
\hline & Number & stices & Average & $\frac{\text { Iron }}{\text { Tent greater }}$ & $\frac{\text { D.25s }}{\text { Aletage }}$ & $\frac{\text { lved solids }}{\text { percent greater }}$ & & $\frac{1 \text { lor ide }}{\text { percent }}$ & $\begin{array}{l}\text { Hardness } \\
\text { Average }\end{array}$ & & $\frac{\text { Color }}{\text { corcent greater }}$ \\
\hline Strean stations & sampies & $=8 / 1$ & $\mathrm{mg} / 1$ & $0.3 \mathrm{mg} / 11$ & $m 8 / 1$ & $500 \mathrm{mg} / 1 \mathrm{i}$ & $\mathrm{mg}_{\mathrm{g} / \mathrm{i}}$ & $250 \mathrm{mg} / 1 \mathrm{i}$ & $\mathrm{mg}_{8 / 1}$ & unzts & 15 units \\
\hline $\begin{array}{l}15-2420 \\
\text { Kastilof Raver } \\
\text { netr Kenei }\end{array}$ & 33 & 5.7 & 0.27 & 26 & 31 & 0 & 1.0 & 0 & 18 & 13 & 33 \\
\hline $\begin{array}{l}15-2580 \\
\text { Kenai River at } \\
\text { Cooper Landing }\end{array}$ & 55 & 4.0 & .12 & 11 & 4 & 0 & 1.0 & 0 & 32 & 8 & 10 \\
\hline $\begin{array}{l}15-2663 \\
\text { Kenki River } \\
\text { et Soldotne }\end{array}$ & 42 & 4.8 & .38 & 38 & 42 & - & 1.1 & 0 & 29 & 9 & 16 \\
\hline $\begin{array}{l}\text { 15-2061.8 } \\
\text { Mosese River } \\
\text { near Ster Iing }\end{array}$ & 14 & 14 & .21 & 24 & 97 & 0 & 1.7 & 。 & 70 & 20 & 62 \\
\hline $\begin{array}{l}15-2665 \\
\text { Beaver Creek } \\
\text { near Kenai }\end{array}$ & 22 & 24 & 1.33 & 95 & 96 & o & 2.3 & 0 & 55 & 25 & 86 \\
\hline
\end{tabular}

The chemical characteristics of water in streams vary with the volume of flow. In general, the dissolved-solids content decreases with increasing flow (fig. 25). The proportion of ground-water runoff relative to surface water, however, may cause a greater range in dissolved-solids content in some streams. Beaver Creek, for example, has a greater range in dissolved-solids content than the Kenai and Kasilof Rivers because during low-flow periods the runoff is principally from ground water high in dissolvedsolids content, whereas during high-flow periods the water is diluted with rain and snowmelt which are low in dissolved solids. The Kenai and Kasilof Rivers have little variation in dissolved solids because the principal source of runoff is snowmelt which is regulated throughout the year by lake storage.

\section{Sediment}

The sediment concentration and total sediment discharge of glacial streams in the Kenai-Soldotna area are relatively small in relation to the amount of stream discharge (table 8; fig. 26). This is caused by reduction in stream sediment load in large lakes, which allows the coarse sediment to 


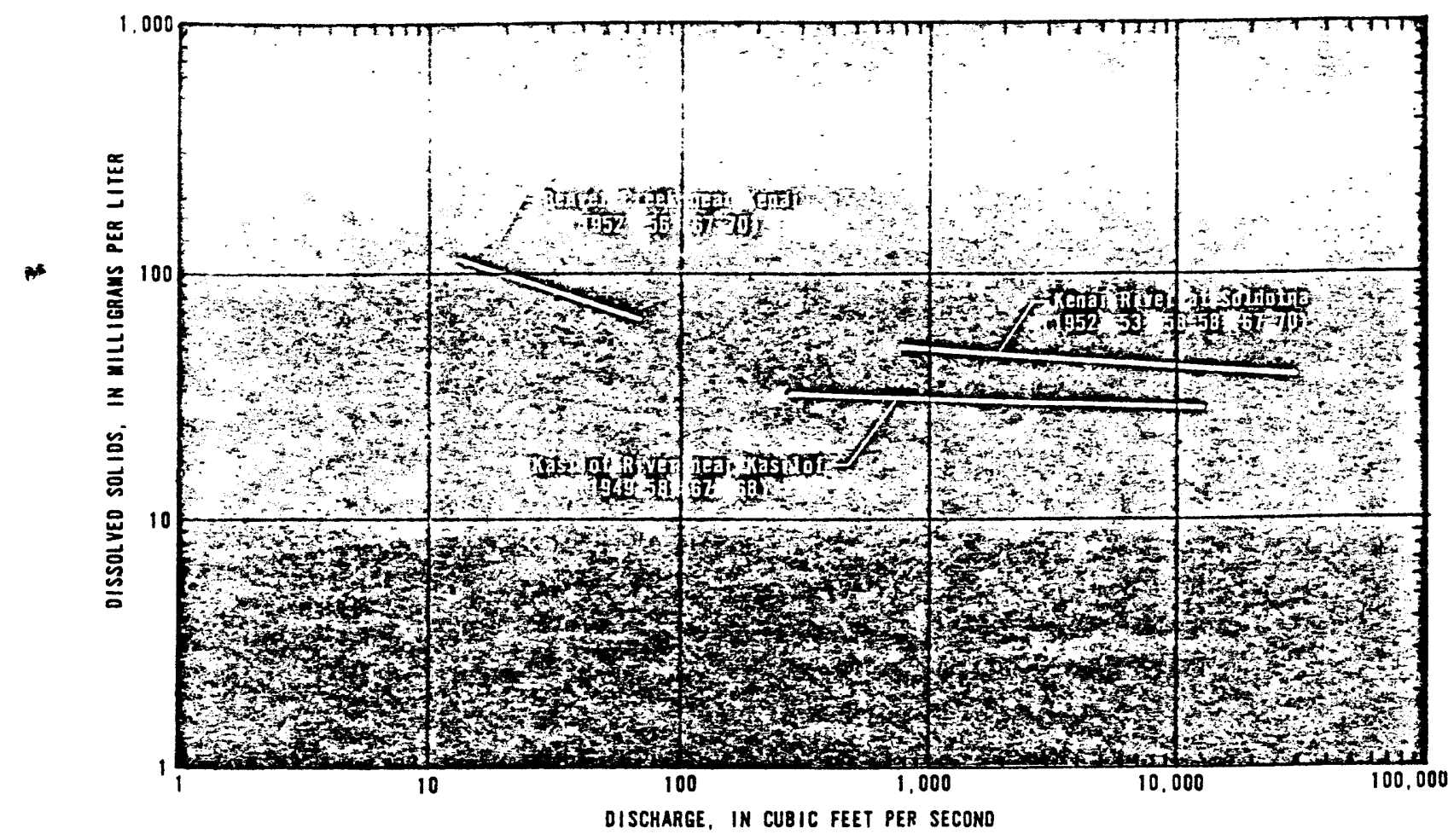

Figure 25.--Comparison of dissolved-solids content with discharge of the Kenai and Kasilof Rivers and Beaver Creek.

settle. However, these streams do contain concentrations of fine suspended sediment throughout the year, the resulting turbidity making the water undesirable for some uses.

The suspended-sediment content increases with amount of water discharged (fig. 26). The highest sediment discharge of glacial streams in these drainage basins occurs during storms that coincide with peak runoff from glaciers. For

- example, the highest sediment concentration and sediment discharge in the Kenai River at Soldotna occurs when the Funny and Killey Rivers are discharging sediment-laden storm runoff into the Kenai River, which is already laden with glacial flour. Data are not available to characterize sediment concentrations and sediment discharge in norigiaciai streams; however, during most of the year, it is sigrificantly less than in glacial streams. 


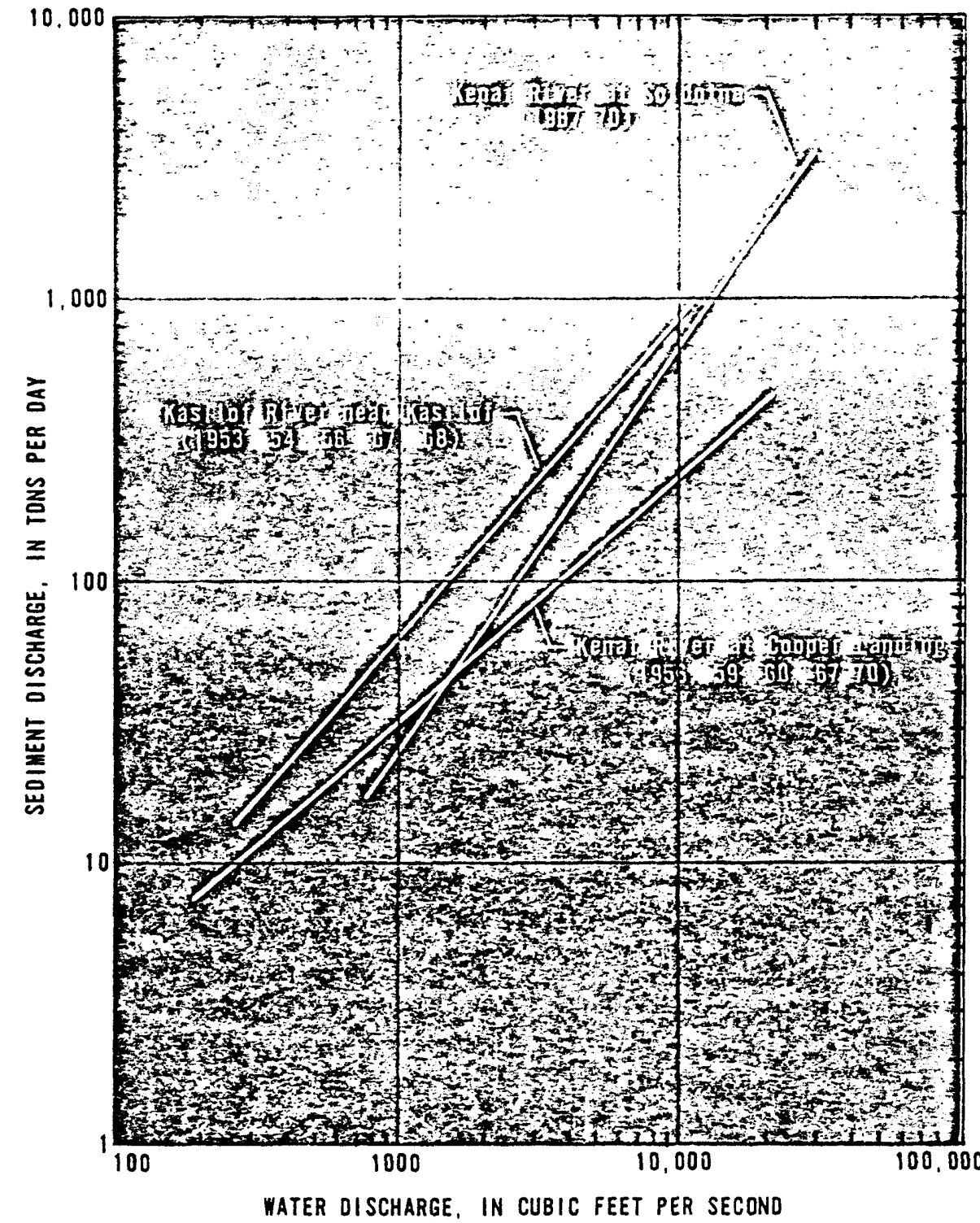

Figure 26.--Comparison of suspended-sediment discharge with water discharge of the Kenai and Kasilof Rivers.

Table 8.--Summary of suspended-sediment data.

\begin{tabular}{l|c|c|c|c}
\hline \multirow{2}{*}{ Stream station } & \multicolumn{2}{|c|}{$\begin{array}{c}\text { Sediment concentration } \\
\text { (milligrams per liter) }\end{array}$} & \multicolumn{2}{|c}{$\begin{array}{c}\text { Sediment discharge } \\
\text { (tons per day) }\end{array}$} \\
\cline { 2 - 5 } & Minimum & Maximum & Minimum & Maximum \\
\hline $\begin{array}{l}15-2420 \\
\text { Kasilof River } \\
\text { near Kasilof }\end{array}$ & 15 & 45 & 17 & 1,000 \\
$\begin{array}{l}15-2580 \\
\text { Kenai River } \\
\text { at Cooper Landing }\end{array}$ & 4 & 72 & 7.9 & 470 \\
$\begin{array}{l}15-2663 \text { Kenai River } \\
\text { at Soldotna }\end{array}$ & & & & \\
\end{tabular}




\section{Temperature}

Measured surface-water temperature in the Kenai-Soldotna area ranges from near freezing to $17^{\circ} \mathrm{C}\left(62^{\circ} \mathrm{F}\right)$. The highest water temperatures occur in the hot summer months as shown in figure 27, a graph of maximum and daily water temperature and stream discharge for Beaver Creek. A wide range in diurnal and day-to-day temperature occurs during the period May to July. Beaver Creek is ice-covered from mid-october to midApril or May; thus approximately 50 percent of the time the water temperature is less than $0.3^{\circ} \mathrm{C}\left(32.5^{\circ} \mathrm{F}\right)(\mathrm{fig} .28)$.

Periodic water-temperature measurements for the Kenai River at Soldotna indicate a seasonal trend similar to Beaver Creek (fig. 29). However, freezeup does not occur until mid-November or December and breakup can be as early as February. This shorter period of ice cover is due to the. relatively warmer water discharged from Skilak Lake into the river.

\section{Salt-Water Encroachment - Kenai River}

The nature of salt-water encroachment caused by tides into the lower reaches of the Kenai River should be considered in the planning for any water-withdrawal or waste-disposal facilities in that area. To evaluate this, observations and measurements of salt-water encroachment in the Kenai River were made for a 10-hour tidal period during the low-flow period and maximum tidal period of May 2, 1969. At the time of observation, the Kenai River was discharging 1,400 cfs (a flow that is equaled or exceeded 84 percent of the time; see fig. 7), and the predicted high-tide stage at the Kenai River entrance was 22 feet (U.S. Dept. of Commerce, 1969). 

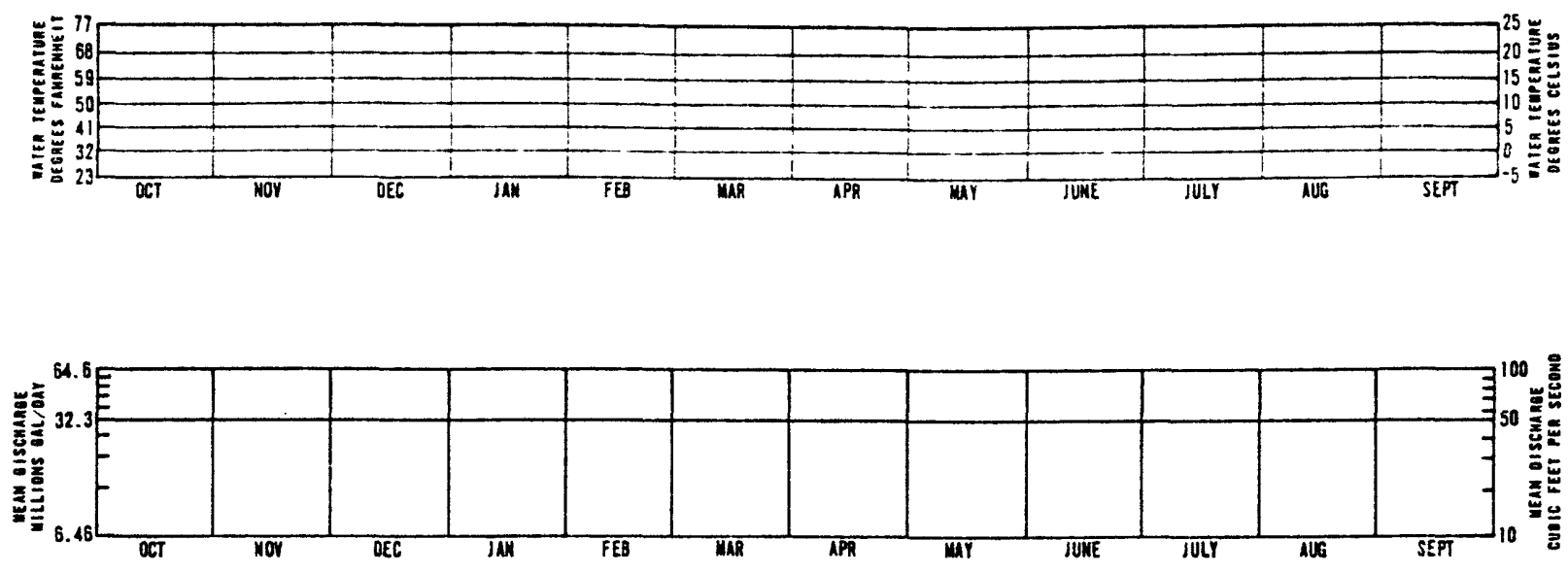

Figure 27.--Comparison of temperature with daily discharge for station 15-2665.00: Beaver Creek near Kenai, 1969-70.

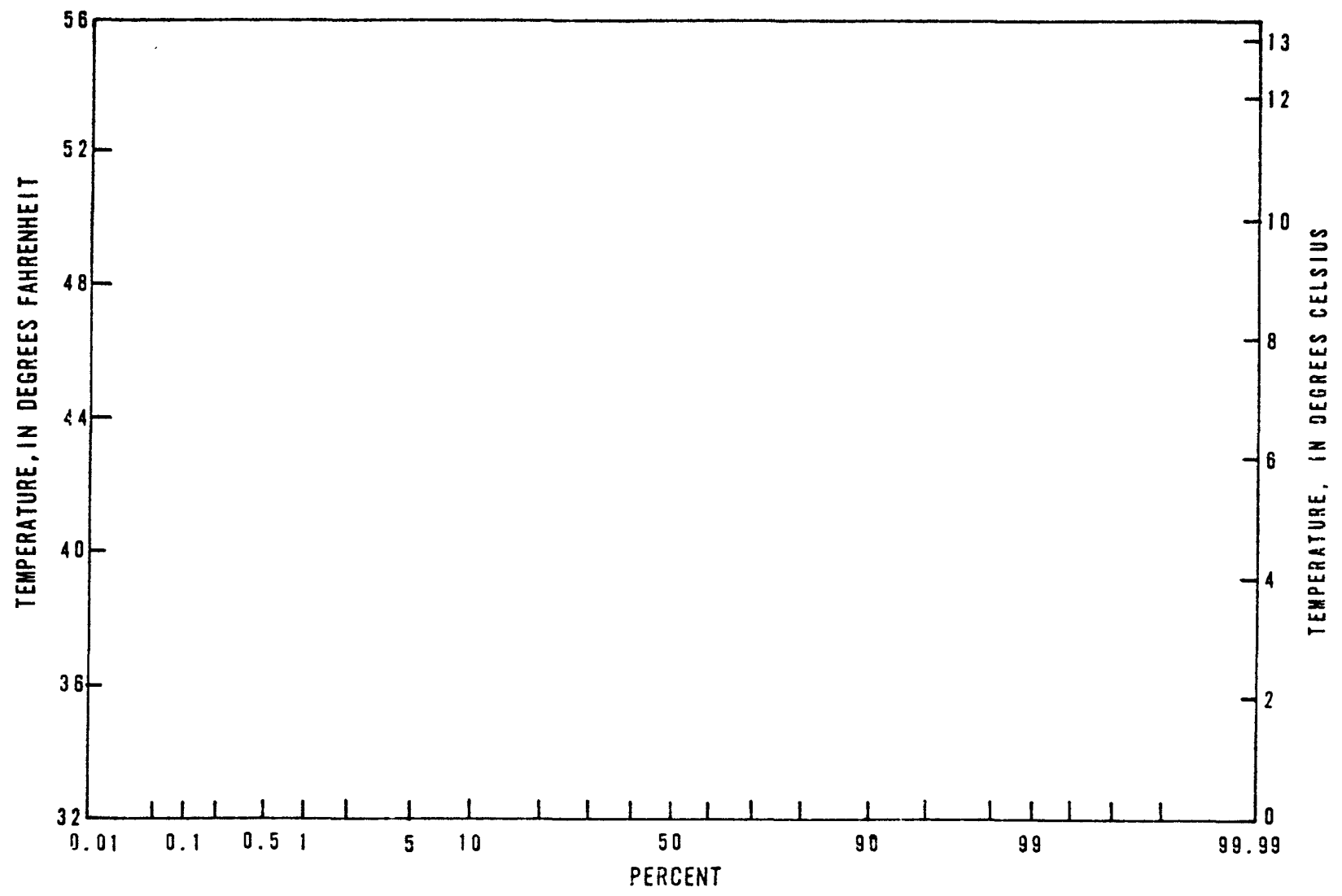

Figure 28.--Cumulative frequency curve of water temperature, Beaver Creek near Kenai, 1969-70. 


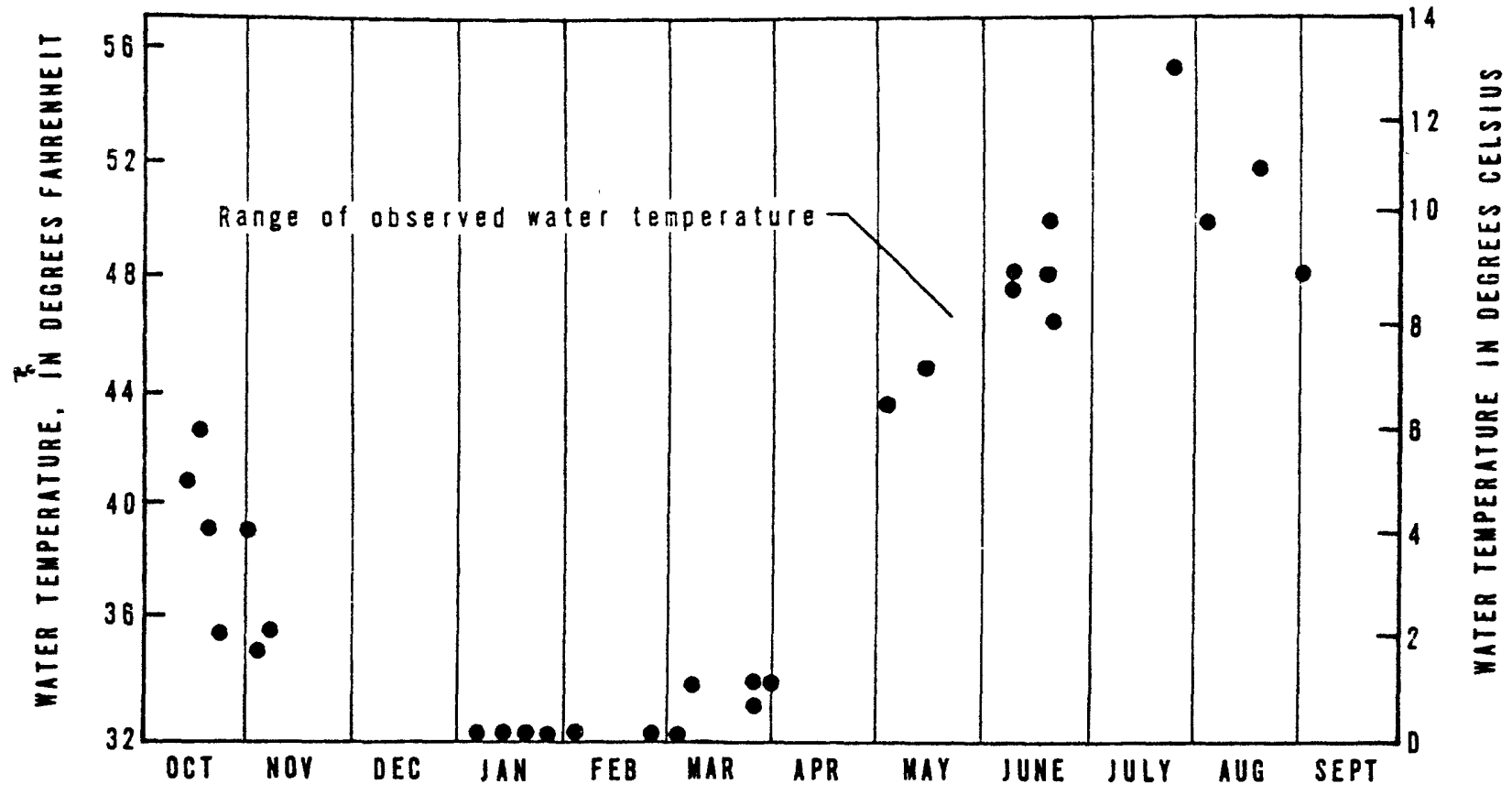

Figure 29.--Seasonal variability of water temperature, Kenai River at Soldotna.

Figure 30 illustrates the extent, magnitude, and nature of : salt-water encroachment into the Kenai River at this time. At the mouth of the river specific conductance of the water (a general indicator of dissolved-mineral content) increased from 2,990 to 42,700 micromhos during the flood tide when water stage rose 23.1 feet. Water with a maximum chloride content was obtained during the peak tidal stage.

At Eagle Rock, 12 miles above the river mouth, specific conductance increased from 81 micromhos ( $1 \mathrm{mg} / 1 \mathrm{chloride}$ ) to 1,100 micromhos $(392 \mathrm{mg} / 1$ chloride) during the flood tide when water stage rose io feet. Maximum chloride coincided

- with the maximum tidal stage, and both lagged 1 hour behind the maximum inflow velocities. Because of the steeper river gradient above Eagle Rock, salt water did not encroach very far above this point. At observation points, the maximum water velocities were observed during the flood tide, indicating that the greatest transporting energy is into the Kenai River mouth; sediment and solid wastes would thus tend to accumulate in the Kenai estuary. 


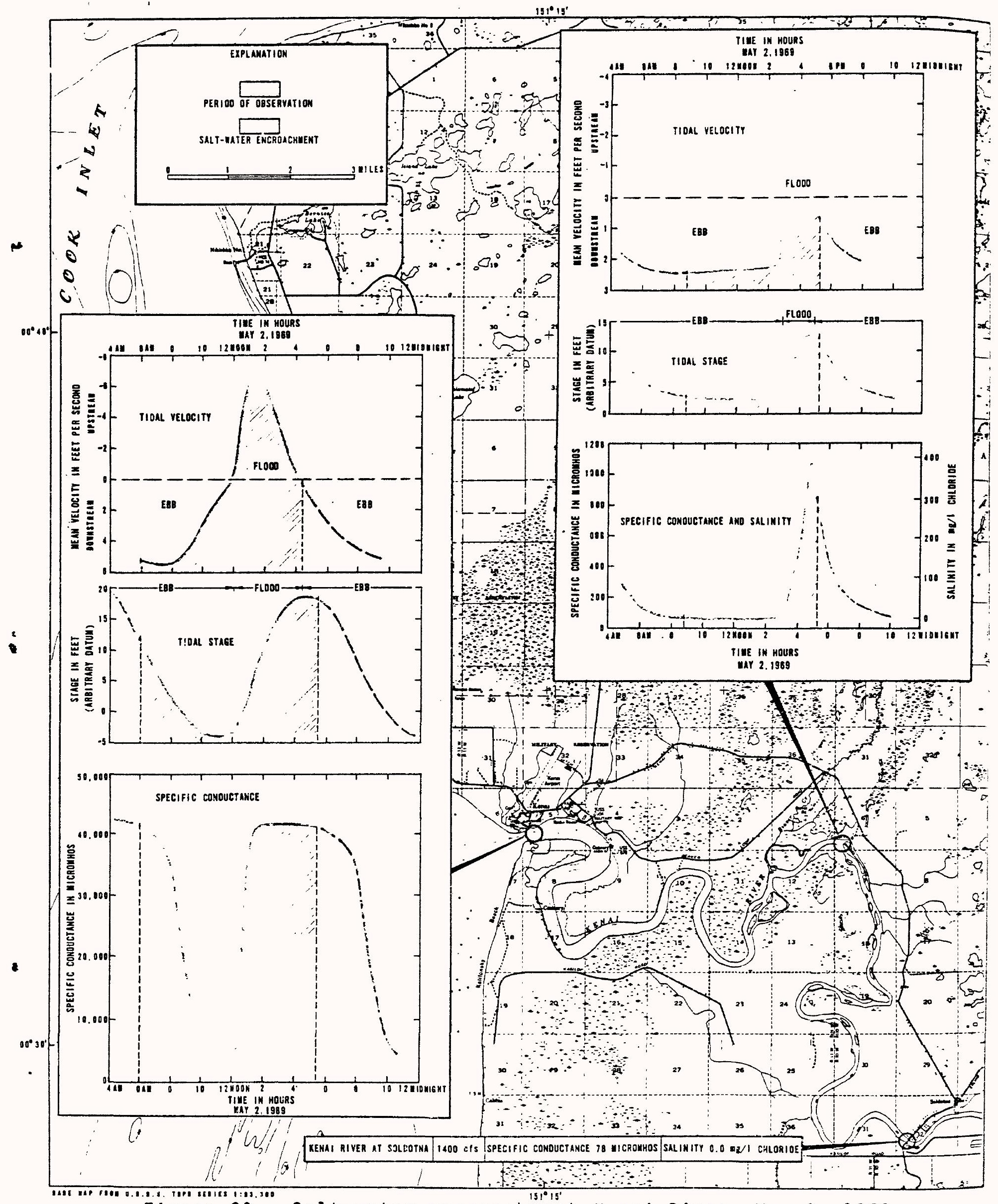

Figure 30.--Salt-water encroachment, Kenai River, May $2,1969$. 


\section{FUTURE DEVELOPMENT OF WATER RESOURCES}

Future water requirements in the Kenai-Soldotna area are difficult to estimate because a trend for industrial and population growth is not firmly established. In 1970, approximately 25 percent, or $0.9 \mathrm{mgd}$, of the water pumped was used for domestic purposes. Assuming a 4 percent per annum increase in population and a per capita increase of water use from 100 to $150 \mathrm{gpd}$, domestic water use should double by 1977. During 1970, North Kenai industry used approximately $2.4 \mathrm{mgd}$. If the number of petro-chemical plants located in North Kenai were to double, depending on the specific need of each, additional demand could range from 1 to $4.5 \mathrm{mgd}$.

The projected domestic water requirements can probably be satisfied by ground-water wells. However, expanded industrial development in North Kenai may require new sources of water or proper management of the present source.

A surplus of ground water is probably available from water-bearing deposits underlying the cities of Soldotna and Kenai and from the Beaver Creek valley and the Kenai River valley downstream from Soldotna. An estimated 1 to $3 \mathrm{mgd}$ supply, in addition to the 5-year projected municipal requirement, could be developed near Soldotna or in Beaver Creek valley. However, further testing is required to verify the potential of ground-water development in the Kenai River valiey downstream from soldotna. In addition, artesian ground water could be further developed in North Kenai or in the drift deposits east of North Kenai, but the effects on the water-table system cannot be evaluated at this time.

The water-table aquifer of Kenai could be deveroped; but because of the fine sediments, low permeability, and limited available drawdown, high-capacity wells are difficult to construct. Also, the high iron content of water from this aquifer restricts its development for most purposes. However, 
expanded development of the Beaver Creek artesian aquifer would utilize some water from the water-table aquifer by inducing vertical leakage.

The developer needing large supplies of ground water must employ sophisticated techniques in the exploration, development, and management of the ground water. Subsurface exploration programs that employ appropriate cost-saving techniques should be designed; production wells should use up-to-date techniques of well construction, screening, and developing. Many attempts to construct high-capacity production wells in the study area have failed, generally because of the presence of fine-grained water-bearing material incapable of high yields. One possible solution to this problem would be to increase the diameter of the holes and to gravel pack the wells artificially.

Once a ground-water reservoir is developed, it must be properly managed to insure wise utilization. Consequently, management objectives of all agencies or persons dependent on the water resources in the area must be coordinated.

Effective utilization of the ground-water reservoir requires continual inventory of components in the hydrologic cycle, such as quantity in storage, recharge and discharge, and, in addition, the rate of movement of water through the reservoir. In the Kenai-Soldotna area, this inventory should include records of streamflow, ground-water level changes, ground-water pumpage, lake-level changes, discharge from springs, precipitation, and estimates of evapotranspiration.

To determine whether moderate quantities of water can be withdrawn from a given ground-water reservoir is generally not difficult. But to determine the maximum amount of water that can be withdrawn without producing an undesirable result requires detailed knowledge of the geologic framework of the hydrologic system and planning decisions as to the extent that undesirable results can be tolerated. This is difficult 
to do because normally the potential of a basin cannot be determined in advance of development, However, detailed hydrologic information concerning the geohydrologic system and the cause-effect relationships of ground-water pumpage, can be used in constructing electric-analog or mathematical models to predict aquifer response. The construction and refinement of the model are dependert on historical records of ground-water pumpage and head changes. Even after a model of the aquifer has been constructed, the hydrologist cannot estimate the maximum yield until the water users define precisely the undesirable results that are to be avoided.

Questions that must be considered may include:

1. What is tolerable drawdown, and over what areal extent can it occur?

2. What is the relative value of the swamp lands? Should they be preserved for wildiffe, or should the lowering of water levels be allowed with the associated benefits of conserving water by reducing evapotranspiration and making the land habitable for man?

3. Can changes in lake levels be tolerated, and to what extent?

4. Can the reduction of ground-water runoff be tolerated?

In any management decision; it should be realized that optimum development is usually achieved when the average recharge is balanced by the average discharge and when the discharge for nonbeneficial purposes has been reduced to a minimum. In most years, however, such a balance will not be achieved. During dry years, ground water is drawn from storage, water levels decline, and recharge from lakes and straams may increase. During wet years, lakes are filled, streams 
flow above normal discharge, and the ground-water reservoir is replenished. Maximum use of ground-water reservoirs cannot be achieved by holding the storage constant; it is achieved by drawing on storage during dry years, but only to the extent that the storage can be replenished during wet years.

The largest untapped source of water is the Kenai River. The lowest recorded flow on the Kenai River at Soldotna was 770 cfs. If only 10 percent of this flow, or $77 \mathrm{cfs}$, were withdrawn from the river, it would provide $50 \mathrm{mgd}$. However, treatment of the silt-laden river water could be a problem. To insure that the Kenai River remains a potential source of water, its chemical and biological quality must be maintained.

There is a good potential for development of the water resources in the Kenai-Soldotna area, but far-sighted and rational planning will be required to develop the resource wisely and economically. An ideal water plan calls for a water-supply system that can handle the current needs most efficiently but that can be expanded as tine demands for water grow. To date, the most efficient water system for the area has utilized ground-water wells near the points of intended use. With increased demands, it may be necessary to consider transferring water from areas of surplus to areas of deficiency. Thus, if all future industrial expansion is in the North Kenai area, importing water through a unified system may eventually be necessary. Tryck, Nyman and Hayes (1970) have estimated that North Kenai water use would have to reach $6.5 \mathrm{mgd}$ to justify economically water importation from the Kenai River. However, this estimate is based on the assumption that local ground water will not be exhausted at some lower rate of water use.

Whether the water is taken from the Kenai River or from ground-water reservoirs requires economic evaluation of waterwithdrawal facilities, treatment, costs, and transmission lines. Loca? development of ground water will probably be 
the most economical means of supply until increased demand lowers the unit cost of a unified system. However, a higher unit cost would have to be tolerated if local ground-water supplies prove inadequate. Continued ground-water development should be compatible with a future unified water system. The optimum unified system might include conjunctive use of both surface and ground water. Surface water might be the major source because of its large potential for development. However, ground water would be included in the system to warm the water in the winter, when the river water is at or near $0^{\circ} \mathrm{C}\left(32^{\circ} \mathrm{F}\right)$ and to supplement the surface water during times of heavy load on the treatment facilities, such as during periods of peak sediment concentration in the Kenai River.

Such a unified system might include: (1) Several million gallons per day of surface water from an infiltration gallery or run-of-the-river intake of Kenai River somewhere above Eagle Rock (fig. 30), (2) $3 \mathrm{mgd}$ from ground-water wells near Soldotna, (3) $3 \mathrm{mgd}$ from ground-water wells in Beaver creek valley, and (4) 2 to $6 \mathrm{mgd}$ from ground-water wells near North Kenai. 


\section{REFERENCES}

Adams, Corthe 11, Lee, Wince and Associates, 1968, Water supplydistribution system and sewer collection-treatment-disposal system: Adams, Corthell, Lee, Wince and Associates, Consulting Engineers, Anchorage, Alaska, $70 \mathrm{p}$.

Anderson, G. S., 1971, Ground-water exploration in Beaver Creek valley near Kenai, Alaska: U.S. Geol. Survey open-file report, $27 \mathrm{p}$.

Anderson, G. S. and Jones, S. H., 1968, Progress report, water resources study of the Kenai Peninsula Borough: U.S. Geol. Survey Admin. report, $21 \mathrm{p}$. 1969, Water resources study of the Kenai Peninsula Borough, progress report: U.S. Geol. Survey Admin. report, $16 \mathrm{p}$.

1971, Hydrologic data of the Kenai-Soldotna area, Alaska:

U.S. Geol. Survey open-file report, $58 \mathrm{p}$.

Childers, J. M., 1970, Flood frequency in Alaska: U.S. Geol. Survey open-file report, $30 \mathrm{p}$.

Dames and Moore, 1967, Ground water investigation fertilizer plant near Kenai, Alaska: Dames and Moore, Consulting Engineers, New York, N. Y., 80 p.

Hantush, M. S., 1960, Modification of the theory of leaky aquifers: Jour. Geophys. Research, v. 65, no. 11 , p. $3713-3725$.

Karlstrom, T.N.V., 1958, Ground conditions and surficial geology of the Kenai-Kasilof area, Kenai Peninsula, south-central Alaska: U.S. Geol Survey Misc.

Geo1. Inv. Map I-269.

1964, Quaternary geology of the Kenai lowland and giacial history of the Cook Inlet region, Alaska:

U.S. Geol. Survey Prof. Paper 443, $69 \mathrm{p}$. 
Meinzer, 0. E., and Stearns, N. D., 1929, A study of ground water in the Pomperaug basin, Connecticut: U.S. Geol. Survey Water-Supply Paper 597-B, 146 p.

Piper, A. M., 1944, A graphic procedure in the geochemical interpretation of water analyses: Am. Geophys. Union Trans., v. 25, p. 914-923.

Post, Austin, and Mayo, L. R., 1971, Glacier dammed lakes and outburst floods in Alaska: U.S. Geol. Suvey Hydrol. Inv. Atlas HA-455.

State of Alaska, Department of Economic Development, 1970 , Look north to Kenai, Alaska: Standard Industrial Survey, Dept. of Econ. Devel., Indus. Devel. Div., Juneau, $8 \mathrm{p}$.

Tryck, Nyman and Hayes, 1970, The Kenai Peninsuia Borough comprehensive water and sewer study: Tryck, Nyman and Hayes, Consulting Engineers, Anchorage, Alaska, $130 \mathrm{p}$.

U.S. Army, Corps of Engineers, 1967, Flood plain information Kenai River: U.S. Army Engineer District, Alaska, Corps of Engineers, $43 \mathrm{p}$.

U.S. Department of Commerce, 1969, Tide tables - West coast of North and South America: Environmental Sci. Services Adm., Coast and Geodetic Survey.

U.S. Geological Survey, 1957, Compilation of records of quantity and quality of surface waters of Alaska through September 1950: U.S. Ge01. Survey Water-Supply Paper $1372,262 \mathrm{p}$.

1964, Compilation of records of surface waters of Alaska, October 1950 to September 1960: U.S. Ge01. Survey Water-Supply Paper 1740, 86 p. 1967, Water resources data for Alaska, 1966 - Pt. 1, Surface water records: U.S. Geol. Survey open-file report, $138 \mathrm{p}$. 
U.S. Geological Survey, 1968, Water resources data for Alaska, 1967 - Pt. 1, Surface water records: U.S. Geol. Survey open-file report, $145 \mathrm{p}$. 1969, Water resources data for Alaska, 1968 - Pt. 1 , Surface water records: U.S. Geol. Survey open-file report, $155 \mathrm{p}$. 1970, Water resources data for Alaska, 1969 - Pt. 1, Surface water records: U.S. Geol. Survey open-file report, $156 \mathrm{p}$.

1971a, Water resources data for Alaska, 1970 - Pt. 1, Surface water records; Pt. 2, Water quality records: U.S. Geol. Survey open-file report, $263 \mathrm{p}$. 1971b, Surface water supply of the United States 1961-65 - Pt. 15, Alaska: U.S. Geol. Survey WaterSuppiy Paper 1936, $342 \mathrm{p}$.

U.S. Public Health Service, 1962, Drinking water standards: U.S. Public Health Service Pub. 956, 61 p.

U.S. Water Resources Council Hydrology Committee, 1967, A uniform technique for determining flood flow frequencies: Washington, U.S. Water Resources Council Bu11. 15, $15 \mathrm{p}$.

Watson, C. E., 1959, Climates of the states, Alaska:

U.S. Weather Bureau 60-49, 24 p. 